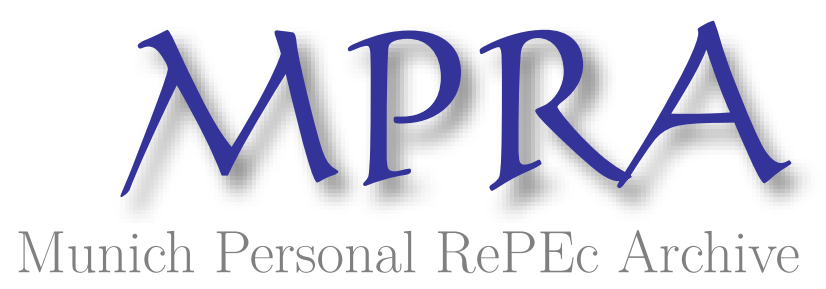

\title{
Venture capital optimal investment portfolio strategies selection in diffusion - type financial systems in global capital markets with nonlinearities
}

Ledenyov, Dimitri O. and Ledenyov, Viktor O.

James Cook University, Townsville, Queensland, Australia

26 November 2013

Online at https://mpra.ub.uni-muenchen.de/51741/

MPRA Paper No. 51741, posted 28 Nov 2013 07:43 UTC 


\title{
Venture capital optimal investment portfolio strategies selection in diffusion - type financial systems in global capital markets with nonlinearities
}

\author{
Dimitri O. Ledenyov and Viktor O. Ledenyov
}

\begin{abstract}
The condensed research article presents some innovative research results on the venture capital optimal investment portfolio strategies selection in the diffusion-type financial systems in the imperfect highly volatile global capital markets with the incomplete information, which are characterized by the asymmetric information flows and impacted by the various types of the nonlinearities. We discuss the venture capital firms with the different organizational structures: the corporation funded venture capital firm, investment bank funded venture capital firm, private equity funded venture capital firm, state funded venture capital firm. We consider the complicated issues on the venture capital optimal investment portfolio strategies selection, evaluation of the possible returns on the investments, and implementation of exit strategies for the venture capital investment schemes. We propose that the information signals can be mixed and self-modulated during the asymmetric information flows in the information transmission channels between the market agents, resulting in the origination of the various types of the nonlinearities such as the high order harmonics, which may have a considerable impact on the venture capital investments in the diffusion-type financial system. These nonlinearities have to be taken to an account during the venture capital optimal investment portfolio strategies selection process, which is all about making the right investment choices with the application of the inductive, deductive and abductive logics. In our opinion, the State of Queensland in Australia is a very attractive place to make the venture capital investments in the hi-tech startups, comparing to other regions in the World. We conclude with the notion that the venture capital can greatly improve the macroeconomic indicators of national economies, creating the new hitech industries, generating the abundant wealth, and increasing the Gross Domestic Product.
\end{abstract}

JEL: C14, C33, D21, D92, G10, G14, G21, G23, G24, L 21 .

PACS numbers: 89.65.Gh, 89.65.-s, 89.75.Fb .

Keywords: venture capital concept, venture capital fund, venture capital investment portfolio and strategy, corporation funded venture capital firm, investment bank funded venture capital firm, private equity funded venture capital firm, state funded venture capital firm, entrepreneurship, theory of firm, wealth creation, econophysics, econometrics, nonlinearities, asymmetric information flows, mixing and modulation of information signals, diffusion-type financial system, imperfect highly volatile global capital markets with incomplete information. 


\section{Introduction}

The venture capital $(V C)$ is considered as an important source of corporate financing in the diffusion-type financial systems in the imperfect highly volatile capital markets with the incomplete information, which are usually characterized by the asymmetric information flows and impacted by the various types of nonlinearities in Jaffee, Russell (1976), Leland, Pyle (1977), Stiglitz, Weiss (1981), Stiglitz (1988), Zhang (2007b), Diaconu (2012). The venture capital firm invests the venture capital in the selected hi-tech startups, which implement the entrepreneurial ideas and compete in the various product and services markets, contributing to the overall growth of national economies in Kirzner (1973), Lucas (1978), Audretsch, Keilbach (2004), Samila, Sorenson (2011).

The diffusion processes have a great impact on the physical - chemical properties of different chemical compounds, hence the diffusion theory has been a subject of intensive research in the physics and chemistry at the research institutions and the leading universities in the $X X-X X I$ centuries in Ledenyov $D O$, Ledenyov V $O$ (2012e), Ledenyov V $O$, Ledenyov $D O$, Ledenyov O P (2012f), Müller (1997). In addition, the intensive experimental measurements on the precise characterization of diffusion processes have been conducted to understand the nature of the diffusion processes in the metals, superconductors, semiconductors and dielectrics at the different internal and external conditions at the research laboratories at the leading universities in the World over the recent decades in Ledenyov V O, Ledenyov D O, Ledenyov $O P(2012 f)$, Ledenyov D O, Ledenyov V O (2012e), Müller (1997), Chu (1997), Goretta (1998).

The general perception among the economists is that the diffusion processes can certainly have a considerable influence on the various econometric parameters of the diffusion-type financial systems, that is why the diffusion theory has been frequently applied to accurately characterize the diffusion - type financial systems in the finances in Bachelier (1900), Osborne (1959), Alexander (1961), Shiryaev (1961, 1963, 1964, 1965, 1967, 1978, 1998a, b, 2002, 2008a, b, 2010), Grigelionis, Shiryaev (1966), Graversen, Peskir, Shiryaev (2001), Kallsen, Shiryaev (2001, 2002), Jacod, Shiryaev (2003), Peskir, Shiryaev (2006), Feinberg, Shiryaev (2006), du Toit, Peskir, Shiryaev (2007), Eberlein, Papapantoleon, Shiryaev (2008, 2009), Shiryaev, Zryumov (2009), Shiryaev, Novikov (2009), Gapeev, Shiryaev (2010), Karatzas, Shiryaev, Shkolnikov (2011), Shiryaev, Zhitlukhin (2012), Zhitlukhin, Shiryaev (2012), Feinberg, Mandava, Shiryaev (2013), Akerlof, Stiglitz (1966), Rothschild, Stiglitz (1976), Stiglitz, Weiss (1981), Richiardi, Gallegati, Greenwald, Stiglitz (2007), Bernanke (1979, 2002, 2004, 2007, 2009a, b, c, d, e, 2010a, b, 2012a, b, 2013a, b, c, d), Bernanke, Blinder (1992), Bernanke, 
Gertler (1995), Bernanke, Reinhart (2004), Bernanke, Reinhart, Sack (2004), Bernanke, Blanchard, Summers, Weber (2013), Shiller, Pound (1989), Stock, Watson (2002), Xiaohong Chen, Hansen, Carrasco (2009), Ledenyov D O, Ledenyov V O (2013f, g, h). In this innovative research article, we would like to limit our detailed research considerations by an assumption that the venture capital investments have place in the diffusion-type financial systems in the imperfect highly volatile capital markets with the incomplete information, which are characterized by the asymmetric information flows and influenced by the various types of induced nonlinearities in Akerlof, Stiglitz (1966), Rothschild, Stiglitz (1976), Stiglitz, Weiss (1981), Richiardi, Gallegati, Greenwald, Stiglitz (2007).

Discussing the early research results on the venture capital investments in the USA, it makes sense to begin with literature review, beginning with the notion that the rise and fall of venture capital have been researched in Gompers (1994). The research topics on the optimal investment, monitoring, and staging of venture capital have been discussed in Gompers (1995, 1996). The empirical analysis of venture partnership agreements has been completed in Gompers, Lerner (1996). The various types of risks during the venture capital investing have been reviewed in Gompers, Lerner (1997). The various investment strategies in the corporate financing, using the venture capital, have been analyzed in Gompers, Lerner $(1998 a$, $b$ ). The analysis of compensation in the $U S$ venture capital partnership and business interests has been completed in Gompers, Lerner $(1999 a, b)$. The full venture capital funding cycle has been described in Gompers, Lerner (1999c). The various determinants of corporate venture capital success have been provided in Gompers, Lerner (2000a). The possible impact of fund inflows on private equity valuation has been reflected in Gompers, Lerner (2000b). The venture capital revolution has been described in Gompers, Lerner (2001). The new ventures funding has been studied in Gompers, Lerner, Scharfstein (2005). The venture capital investment practices have been discussed in Gompers (2007). The venture capital investment cycles have been precisely characterized in Gompers, Kovner, Lerner, Scharfstein (2008). The allocation of venture capital to the successful companies has been shown in Gompers, Kovner, Lerner (2009), Gompers, Lerner, Scharfstein, Kovner (2010). The syndication of VC investments has been investigated in Lerner $(1994 a, b)$. The investment practices by the venture capitalists have been researched in Lerner (1995). The selected research topics on the government as source of venture capital funding in the frames of the SBIR program have been considered in Lerner (1999). Kortum, Lerner (1998) proposed that the venture capital can increase the level of innovation in the society. Kortum, Lerner (2000) assessed the contribution by the VC to the innovation in the hitech industry. Lerner, Schoar, Wongsunwai (2007) researched some organizational aspects of the 
venture capital firm. Lerner (2008) made a few thoughtful research comments on the impact by the economic crisis on the venture capital funding dynamics in the USA. The empirical analysis of venture capital contracts has been performed in Kaplan, Strömberg (2000, 2002, 2003). The advanced researched on the of venture capital contracts has been continued in Kaplan, Strömberg (2004). The private equity returns on investments have been investigated in Kaplan, Schoar (2005). The annualized returns of venture-backed public companies, categorized by stage of financing, have been researched in Shachmurove $Y$ (2001). The annualized and cumulative returns on venture-backed public companies, categorized by industry, have been investigated in Shachmurove A, Shachmurove $Y$ (2004). The annualized returns of ventured-backed public companies, stratified by decades and by stage of financing, have been considered in Shachmurove E, Shachmurove $Y$ (2004). The entrepreneurship, innovation, trade and the growth mechanism of the free-enterprise economies in Shachmurove $Y$ (2007a). The venture capital distribution over the various geographical regions have been analyzed in Shachmurove $Y$ (2007b). The investment activity of venture capital in the United States in the years 1996 through 2005 has been summarized in Shachmurove (2007). The access to venture capital and the performance of venture capital-backed star-ups in Silicon Valley have been analyzed in Zhang (2007). The influences by the legal differences and experience on the financial contracts have been researched in Kaplan, Martel, Strömberg (2007, 2009). The different stages of financing through the evolution of firms from early business plans to public companies have been analyzed in Kaplan, Sensoy, Strömberg (2009). The past, present, and future of venture capital has been described in Kaplan, Lerner (2010). Orman (2008) developed a theoretical model to study the effectiveness of various possible organizational arrangements for the innovative startups and some issues in the startups activities financing by the $V C$ funds in the USA. The effect of the current financial crisis on the venture capital investments in the US Internet firms has been analyzed in Block, Sandner (2009). The decline of the United States venture capital industry, including some propositions on what the federal government should do about it, has been analyzed in Aberman (2009).

Researching the venture capital investments in Canada, the convertible preferred equity puzzle in Canadian venture capital finance has been found in Cumming (2000). The determinants of venture capital portfolio size have been described in Cumming (2001). Th venture capital exits in Canada and the United States have been analyzed in Cumming, MacIntosh (2000). The venture capital investment duration in Canada and the United States has been calculated in Cumming, MacIntosh (2001). The private equity investments in Canada have been overviewed in Cumming, MacIntosh (2002a). The cross-country comparison of full and 
partial venture capital exits has been done in Cumming, MacIntosh (2002b). The extent of venture capital exits in Canada and the United States has been analyzed in the frames of the venture capital contracting and the valuation of high-tech firms research in Cumming, MacIntosh (2002c). The economic and institutional determinants of venture capital investment have been identified in Cumming, MacIntosh (2002d). The law and finance analysis of venture capital exits in emerging markets has been investigated in Cumming, Fleming (2002). A cross-country comparison of full and partial venture capital exits has been completed in Cumming, MacIntosh (2003). The liquidity risk and venture capital finance in Cumming, Fleming, Schwienbacher (2005). The venture capitalist value-added activities, fundraising and drawdowns have been analyzed in Cumming, Fleming, Suchard (2005). The legality and venture capital exits have been discussed in Cumming, Fleming, Schwienbacher (2006). The crowding out private equity in Canada has been analyzed in Cumming, MacIntosh (2006). The contracts and exits in venture capital finance have been researched in Cumming (2008). The preplanned exit strategies in venture capital have been discussed in Cumming, Johan (2008). The style drift in private equity has been considered in Cumming, Fleming, Schwienbacher (2009). The private equity returns and disclosure around the world have been studied in Cumming, Walz, (2010).

Considering the venture capital investments in Europe, it is worth to point out that the chronological history of the VC capital market in Germany has been surveyed in Franzke, Grohs, Laux (2003), making a comparative analysis between the VC capital market in Germany and the $V C$ capital markets in the $U S, U K$ and France. The implication of the $V C$ on the $V C$ funded companies in Germany has been researched in Keilbach, Engel (2003), analyzing the 50,000 German firms of which roughly 1 per-cent is venture funded. Keilbach, Engel (2003) found the multiple evidences that the companies with the higher innovative output (measured by patent applications, corrected for size) and with the higher educated management have a larger probability of being venture funded. The venture capital, ownership structure, accounting standards and IPO underpricing in the cases of German companies have been investigated in Elston, Yang (2010). The underpricing, wealth loss for the pre-existing shareholders and the cost of going public for the venture capital backed startups has been extensively researched in Ferretti, Meles (2011). The first comprehensive comparative analysis between the success of European and American VC-backed portfolio companies has been provided in Kraeussl, Krause (2011). The survival of venture capital backed companies in France has been researched in Pommet (2012). The causal effect by the venture capital backing on the underpricing of the Italian IPOs has been investigated in Pennacchio (2013). 
Reviewing the venture capital investments in Asia, it should be noted that the venture capital in Japan has been analyzed in Clark (1988). The venture capital, bank shareholding, and IPO underpricing in Japan have been studied in Packer (1996). The Japanese IPOs have been researched in Pettway, Kaneko (1996). The investment and operating performance of Japanese IPOs have also been investigated in Cai, Wei (1997). The role by the venture capital in the IPOs in Japan has been researched in Hamao, Packer, Ritter (1999), who made the following comment: "In Japan, most of the major venture capital firms are subsidiaries of securities firms and banks." Hamao, Packer, Ritter (1999) made the interesting observation on the role of VC during IPO process in Japan: "Venture capital playing a certification role in alleviating informational uncertainty about the IPO at the time of issue." The venture capital industries of East Asia have been described in Kenney, Han, Tanaka (2002). The venture capital industry in Singapore has been overviewed in Koh F C C, Koh W T H (2002). Baygan (2003) analyzed the trends in South Korean VC markets and examined the VC policies in South Korea, stating that: "The Korean venture capital market has grown dramatically in recent years, starting from a negligible base in the early 1990s and almost tripling between 1998 and 2001. Korea now ranks among the leading $O E C D$ countries in venture capital investment as a share of GDP and third in the share of venture capital being channeled to start-up enterprises (after the United States and Canada). Venture capital contributed to a proliferation of start-ups in the high - technology sectors such as the information and communications technology (ICT), which accounted for $64 \%$ of venture investments in 2001. Baygan (2003) also highlights an interesting fact: "The government jump-started the venture capital market in 1998 through direct infusion of equity capital, generous tax incentives and equity guarantees, and the designation of certain small firms as "venture businesses"." The $R \& D$ networks of the small and medium size companies in Japan have been researched in Motohashi (2006). The comparative analysis of the biotechnology startups funding by the venture capitalists between the State of Japan and the USA has been completed in Motohashi (2010). The venture capital affiliation with the underwriters and the underpricing of the initial public offerings in Japan has been researched in Arikawa, Imad'eddine (2010).

Analyzing the venture capital investments in Africa, it has to be mentioned that the practical recommendations on the venture capital programme for the South Africa have been formulated in Stillman, Sunderland, Heyl, Swart (1999). The investment criteria, used by the South African venture capitalists in their venture screening and evaluation processes, have been analyzed in Van Deventer, Mlambo (2008, 2009). The challenges and prospects in the earlystage process of the venture capital funding in South Africa have been presented in Jones, 
Mlambo (2009). The rise and fall of South African venture capital have been discussed in Lingelbach, Murray, Gilbert (2009).

Da Rin, Hellmann, Puri (2011) state: "There are a lot of public policy programs relating to $V C$, our understanding of these policies, and our ability as academics to make public policy recommendations remains limited. More and better data on public programs and policies are needed to provide more precise evaluation, and a proper cost/benefit analysis." Da Rin, Hellmann, Puri (2011) continue to explain their vision: "The global VC industry is a relatively young industry that is still undergoing major growing pains and significant structural changes. Researchers need to remember that they are chasing a moving target. We do not expect them to stand still in such a dynamic environment." We think that our research article will improve our understanding on the $V C$ industry modern trends, and present possible approaches to the successful VC financing deals completion.

This research article on the venture capital optimal investment portfolio strategies selection in the diffusion-type financial systems in the imperfect highly volatile global capital markets with the incomplete information, which are characterized by the asymmetric information flows and impacted by the various types of the nonlinearities, aims both:

1) to present an unbiased open discussion forum opinion on the venture capital optimal investment portfolio strategies selection in the conditions of the diffusion-type financial systems in the imperfect highly volatile capital markets with the incomplete information, which are characterized by the asymmetric information flows and impacted by the various types of the induced nonlinearities, and

2) to enhance our general understanding on the nature of the nonlinearities in the finances in Ledenyov V O, Ledenyov D $O(2012 a, b)$, Ledenyov D $O$, Ledenyov V $O(2012 c, d)$, Ledenyov D O, Ledenyov V $O(2013 a, b, c, d, e, f, g, h)$.

This innovative research is written with the use of the extended knowledge base on the nonlinearities in the microwave superconductivity in Ledenyov D O, Ledenyov V O (2012e).

\section{Venture capital investment portfolio allocation theories and practices}

Let us make a definition of the venture capital $(V C)$ organization and show its structural organizational scheme in Da Rin, Hellmann, Puri (2011): "By VC we mean the professional asset management activity that invests funds raised from institutional investors, or wealthy individuals, into promising new ventures with a high growth potential." Da Rin, Hellmann, Puri (2011) continue to explain: "Venture investors are organized in small partnerships of up to a dozen 
individual partners; these are the $V C$ firms. In order to make investment in start-ups, $V C$ firms raise money from institutional investors and wealthy individuals through vehicles called 'funds.' The contract that underlies a fund is traditionally a partnership, where the VC firm exerts active management, and therefore assumes unlimited liability, whereas the investors retain unlimited liability by not interfering with the fund's operations. From this structure originate the common terms of Limited Partners (LPS), for institutional investors and wealthy individuals, and of General Partner (GPs), for the VC firm. During the ten years of the fund's typical lifetime, GPs make the selection of portfolio companies, can monitor, mentor and provide value added services, and ultimately exit from the companies, distributing the returns to their LPs. GPS receive their compensation in the form of a management fee and of performance-based payments called "carried interests" (or just "carry")."

Fig. 1 depicts the scheme of venture capital organization in Da Rin, Hellmann, Puri (2011).

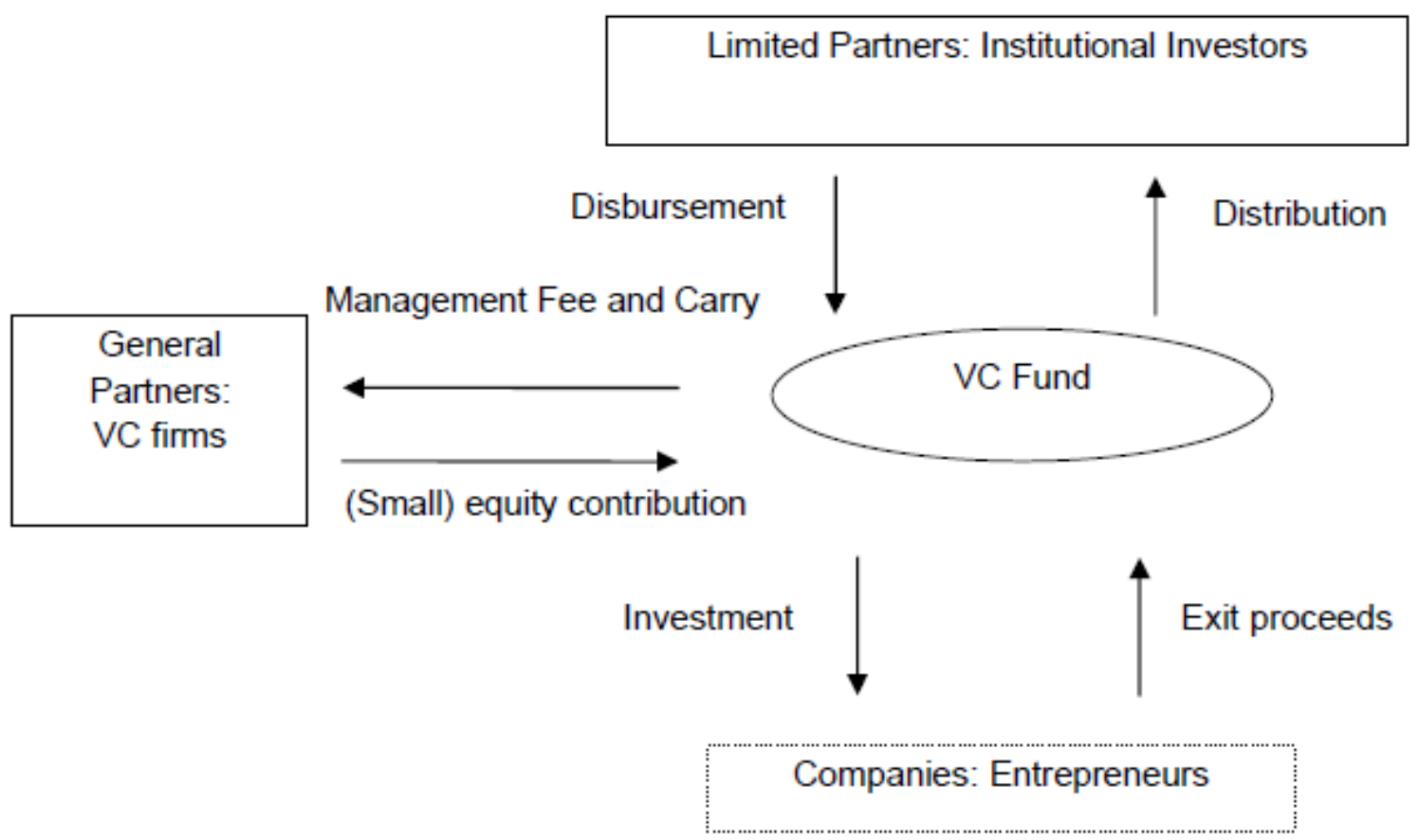

Fig. 1. Scheme of venture capital organization (after Da Rin, Hellmann, Puri (2011)).

Fig. 2 shows the venture capital markets in Baygan, Freudenberg (2000), and Fig. 3 depicts the simple framework of underlying factors and impact of venture capital in Baygan, Freudenberg (2000)). 


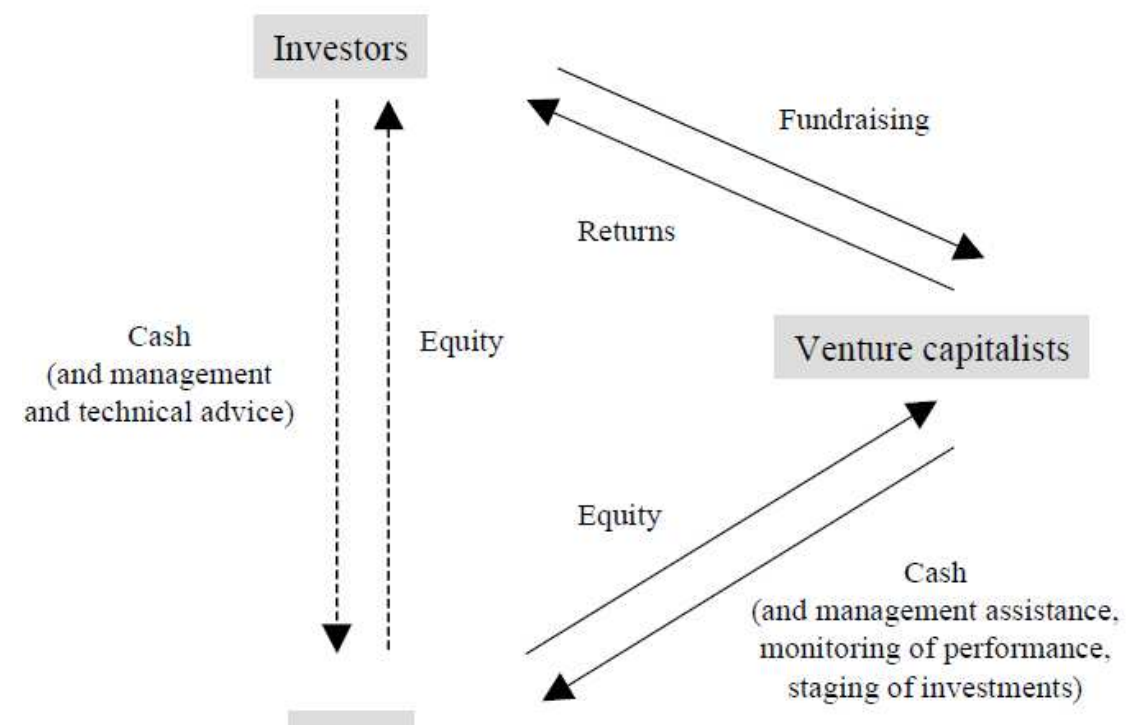

Firms

Fig. 2. Venture capital markets (after Baygan, Freudenberg (2000)).

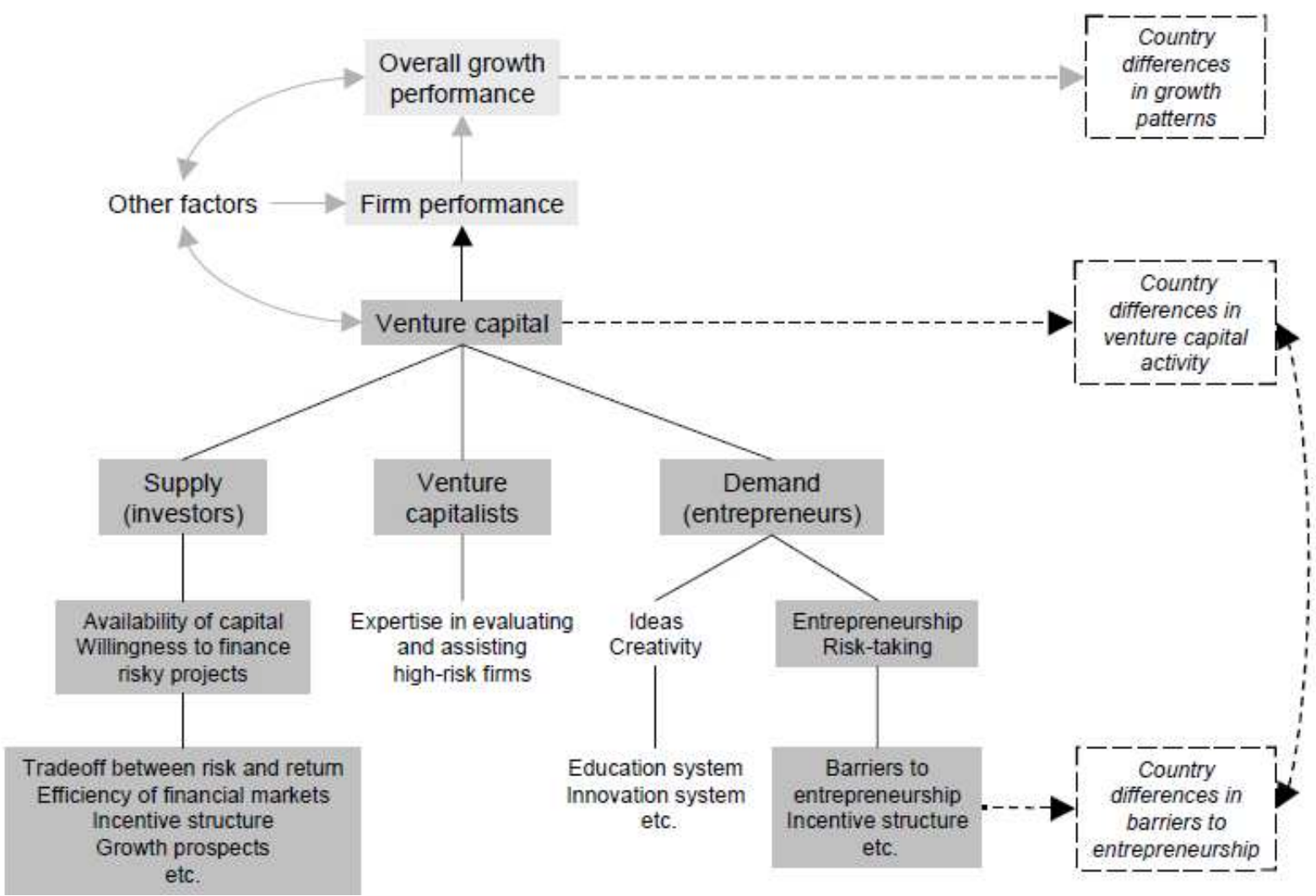

Fig. 3. Simple framework of underlying factors and impact of venture capital (after Baygan,

Freudenberg (2000)).

Let us write, discuss and analyze a few more Venture capital (VC) definitions. Da Rin, Nicodano, Sembenelli (2004) provide the following VC definition: "Venture capitalists are 
increasingly recognized as financial intermediaries that overcome problems of moral hazard and asymmetric information in financial markets Gompers (1995), Lerner (1995).

"Venture capital is a form of intermediation particularly well suited to support the creation and growth of innovative, entrepreneurial companies Hellmann and Puri (2000, 2002), Kortum and Lerner (2000). It specializes in financing and nurturing companies at an early stage of development ('start-ups') that operate in high-tech industries. For these companies the expertise of the venture capitalist, its knowledge of markets and of the entrepreneurial process, and its network of contacts are most useful to help unfold their growth potential Bottazzi, Da Rin and Hellmann (2004), Gompers (1995), Hellmann and Puri (2002), Lerner (1994, 1995), and Lindsey (2003).”

Da Rin, Nicodano, Sembenelli (2006) state: "Venture capital is a form of intermediation particularly well suited to support the creation and growth of innovative, entrepreneurial companies Hellmann and Puri (2000, 2002), Kortum and Lerner (2000).”

Luukkonen (2007) explains: "Research on venture capital has shown that venture capitalists not only provide their investee companies, innovative entrepreneurial ventures, with finance, but impart knowhow in business areas where the investee firms lack capabilities, such as strategic management, recruitment, marketing, and networking; furthermore, they provide the investtee firms with certification and reputation Hellman, Puri (2002); Bertoni, Colombo, (2005)."

Geronikolaou, Papachristou (2008) write: "Venture Capital (henceforth VC) is financial investment channeled to the development of young, dynamic and innovative firms, and along with $R \& D$, plays a major role in technological progress and innovation, most frequently proxied by the number of patent applications or grants at the appropriate level, firm, industry or country level."

Van Deventer, Mlambo (2008, 2009) explain: "Venture capital is a major source of funding for the entrepreneurial community and usually focuses on early stage, more riskorientated, pre-initial public-offering business endeavours."

Block, Sandner (2009) write: "VC is an important means of funding for start-ups in innovative and technology driven industries because it is the vehicle used to turn innovative ideas into products that can be sold to customers. $V C$ particularly matters when firms start to commercialize their innovations, that is, when they develop their products, apply for patents, look for distribution partners, seek first customers, conduct their internationalization strategies, or simply scale up their operations."

Chen, Gompers, Kovner, Lerner (2009) note: "The location of venture capital firms matters for the development of entrepreneurial firms because venture capitalists provide more 
than just risk capital. Venture capital firms typically invest in early-stage and high-technology companies where informational asymmetries are high. These are firms have highly uncertain future prospects and the potential for agency conflicts are severe. Venture capital funding contracts provide for staged financing and venture capitalists are constantly evaluating their portfolio companies (see, for example, Sahlman (1990), Gompers (1995), and Kaplan and Stromberg (2003)). Venture capitalists are actively involved in the governance of the companies they fund through board membership, management recruiting, and the provision of management incentives."

Inci, Barlo (2010) note: "Unlike banks, VCs are not passive investors. They are specialized financial intermediaries who take considerable control in their portfolio. Protective provision terms in contracts allow them to veto transactions that are unfavorable to them and board control gives them the ability to initiate new transactions."

Diaconu (2012) adds: "Venture capital firms do not only provide resources for financing of projects, but they give also experience in research activities and diffusion of innovations, shaping the company's business strategy."

Lazarevski, Mrsik, Smokvarski (2012) state: "Venture capital is an important intermediary in financial markets, providing capital to firms who otherwise have difficulties attracting financial support. Moreover, venture capital funds provide managerial expertise to the company they are investing in, and have impact on the overall economy through innovation, job creation, economic growth, increased competition and improved corporate governance."

Gvazdaityte A (2012) suggests the following definition of the venture capital concept: "Venture capital (VC) - defined as equity or equity-linked investments in young, privately held companies, where the investor is a financial intermediary who is typically active as a director, an advisor, or even a manager of the firm Kortum (1998). American literature understands it to be an investment by specialized venture capital organizations (VC funds) in high-growth, high-risk, often high-technology firms that need capital to finance growth Black and Gilson (1998). While in rare instances in Asia $V C$ is considered as a superset, including higher risk, smaller investments and all private type investments due to a lack of start-ups or early stage hightechnology companies Wong (2005). Concerning the classical concept of VC capital, they should more rightly be called private equity investors than venture capitalists. Van (2000) describes venture capital as a capital needed for the launch, early development and expansion of mostly high-tech companies with profit expectations."

Pommet (2012) writes: "A key function of VC firm is to provide funding and expertise to innovative companies with high growth potential." 
Pennacchio (2013) explain: "The importance of venture capital is widely recognized in both developed and emerging countries. Providing an important source of equity funding and often supporting the management of financed firms with their domain expertise, venture capitalists facilitate the birth and the growth of new firms, especially in high technological industries. Moreover they facilitate the entrepreneurs in dealing with other financing providers: private investors, financial intermediaries, and lastly, equity markets."

Alqatawni (2013) write: "The venture capital (VCs) is a powerful equity financing resource that addresses the funding necessary of entrepreneurial businesses in particular in environments of uncertainty Rosenbusch (2012). Venture capital is one the most influential factor underlying the economic growth of some regions within the United States Samila (2011). The classical definition of $V C s$ is a wealthy person or progressive financial institution that is willing to provide sufficient risk capital to appraise the specific opportunity and provide financial backing for its introduction to the market place Charpie (1967)."

Let us summarize all the $V C$ definitions and other research findings by saying that, in the case of most innovative start ups, the funding of companies can be done with the use of venture capital in Sau (2007): "Venture capital (VC) takes the form of an intermediary collecting financing from a group of investors (banks, pension funds, insurance companies and foundations) and investing it in the share capital of newly instituted, highly innovative firms." Sau (2007) continues to explain: "In the first place the venture capitalist attends to the screening of the innovative firms, so as to reduce the degree of information asymmetry existing ex-ante. In fact, the intermediary is often in possession of specific technical competence which improves as his work of mediation grows, allowing for a shrewder selection of projects than normally made by a generic outside investor-financer or a bank Ueda (2000). Moreover, by granting risk-capital the venture-capitalist not only has the possibility of appropriating part of the value generated by the firm but can also perform various, very particular functions ranging from managerial consultancy to monitoring and even control of the venture-backed firm. As intermediary the venture-capitalist carries out the vital activity of information production, generally performed by the banks in the case of firms operating in the traditional sectors. Thus the venture-capitalist not only has the function of financing in the strict sense, but also provides services that are not strictly financial but which prove fundamental17 in the case of innovative firms, above all in the early stages of development."

In the case of the publicly traded companies, the financing of companies can be done with the use of bank credit directly in Sau (2007): "Bank credit proves preferable to the direct issue of shares for two reasons basically: 1) the banks are able to apply screening and delegated 
monitoring directly to the firms: this reduces the degree of information asymmetry, thereby minimizing the agency cost of outsider financing Diamond (1984);2) in an environment of imperfect, asymmetrical information the credit agencies take on the function of producing information Stiglitz (1985); Stiglitz-Weiss (1988), which has indirect positive effects on the very value of the firms financed. In fact, obtaining a loan often entails an increase in share prices James (1987); Bayless - Chaplinsky (1990); Alam - Walton (1995); Jong-Veld (2001) since, by the very fact of obtaining financing, the firms' reputation is enhanced to the eyes not only of clients and suppliers, but also of other potential investors-financers Diamond (1991)."

Thus, we can see that the venture capital represents a hybrid form of financing in Sau (2007): "Venture capital appears as a hybrid form of financing: it consists in investment in riskcapital, but is also characterized by the function of intermediation performed by the venture capitalist. Over and above the traditional activities of screening and monitoring, with venture capital financing it is also possible to allocate power of control over decisions Kaplan-Stromberg (2000, 2002), depending on the performance of the venture-backed firm. In this way $V C$ succeeds in reconciling the points of force at work in the market-centered financial system with those of the bank-centered system Black-Gilson (1998); Rajan-Zingales (2001)."

Let us comment that the $V C$ industry plays an important role in the national economy growth, analyzing the VC funding in the USA, Orman (2008) writes: "One of the major developments in U.S. capital markets in the recent decades has been the dramatic growth of the venture capital industry: While the amount of funds committed to venture capital was less than half a billion in 1978 , it has risen over $\$ 30$ billion by 2007 , with a peak of about $\$ 100$ billion in 2000 (in 2002 dollars). This change was spurred in large part by the Department of Labor's 1979 decision to relax the "Prudent Man Rule", which had previously obstructed pension funds from investing substantial amounts of money in high-risk start-up ventures. Since then venture funds have been behind many of the exceptionally innovative companies, including Cisco, Genentech, and Google." Orman (2008) continues to provide the multiple example of the VC funding impact on the US economy: "The dramatic growth of the U.S. venture capital since the late 1970's (a significant development in capital markets) and the accompanied explosion of innovation produced by small companies is a case in point. Even a casual observation suggests that a disproportionate share of path-breaking inventions in biotechnology, semiconductors, hard disk drives, minicomputers, software, and the internet has come out of small venture-backed companies. Examples of such companies include Cisco, Seagate, Sun Microsystems, Oracle, Compaq, Google, eBay, Amazon.com, Genentech, Amgen, and countless others." Geronikolaou, Papachristou (2008) add: “According to Gompers and Lerner (2001), some of the most 
renowned high-tech innovators in the US, such as Apple Computers, Cisco Systems, Genentech, Microsoft, Netscape, and Sun Microsystems, have developed thanks to VC assistance."

The interesting fact is that most of the VC firms are located in the financial and hi-tech clusters regions in the USA as explained in Chen, Gompers, Kovner, Lerner (2009): "From Silicon Valley to Herzliya, Israel, venture capital firms are concentrated in very few locations. More than half of the 1,000 venture capital offices listed in Pratt's Guide to Private Equity and Venture Capital Sources are located in just three metropolitan areas - San Francisco, Boston, and New York. More than $49 \%$ of the U.S.-based companies financed by venture capital firms are located in these same three cities." Chen, Gompers, Kovner, Lerner (2009) continue to present the results of their research analysis: "Venture capital firms are likely to locate in areas that offer them the highest concentration of profitable investments since geographically close investments are easier to for the venture capitalist to monitor. Travel to other geographies is costly and will be undertaken only when an investment offers prospects for a high enough return to, in expectation, compensate the venture capitalist for the additional time and money associated with monitoring a distant investment. The resulting concentration of venture capitalists and entrepreneurs may pose grounds for concern given the positive public externalities associated with the establishment of new firms." We would like to add a comment that the financial clusters and the high - tech clusters are not always located at the same places in the USA, however the presence of the financial clusters and the high - tech clusters at the same region makes a great impact on the successful VC industry development in this particular region.

Lerner (2012) points out on the presence of cyclicality in the venture capitalist industry: "The recent changes in the venture capital market have been far from the first such cycles in the venture market. Charts 2 and 3 depict the changing amount of venture capital funds raised and the returns from these funds." Lerner (2012) makes one more similar comment: "As I have highlighted, venture capital is an intensely cyclical industry, and the impact of venture capital on innovation is likely to differ with this cycle."

Let us illustrate the venture capital investments dynamics in the USA, analyzed in the research articles by the various authors in Lerner (2012), Gompers (2002), Shachmurove Y (2007). Fig. 4 shows the venture capital fund raising over the time period of $1969-2001$ in Lerner (2012), and Fig. 5 depicts the returns to the venture capital investments in the time period of 1974 - 2001 in Lerner (2012). Fig. 6 shows the venture capital fund - raising and returns through 1969 - 1994 in Gompers (2002), and Fig. 7 presents the venture capital fund - raising and returns through 1969 - 2000 in Gompers (2002). 


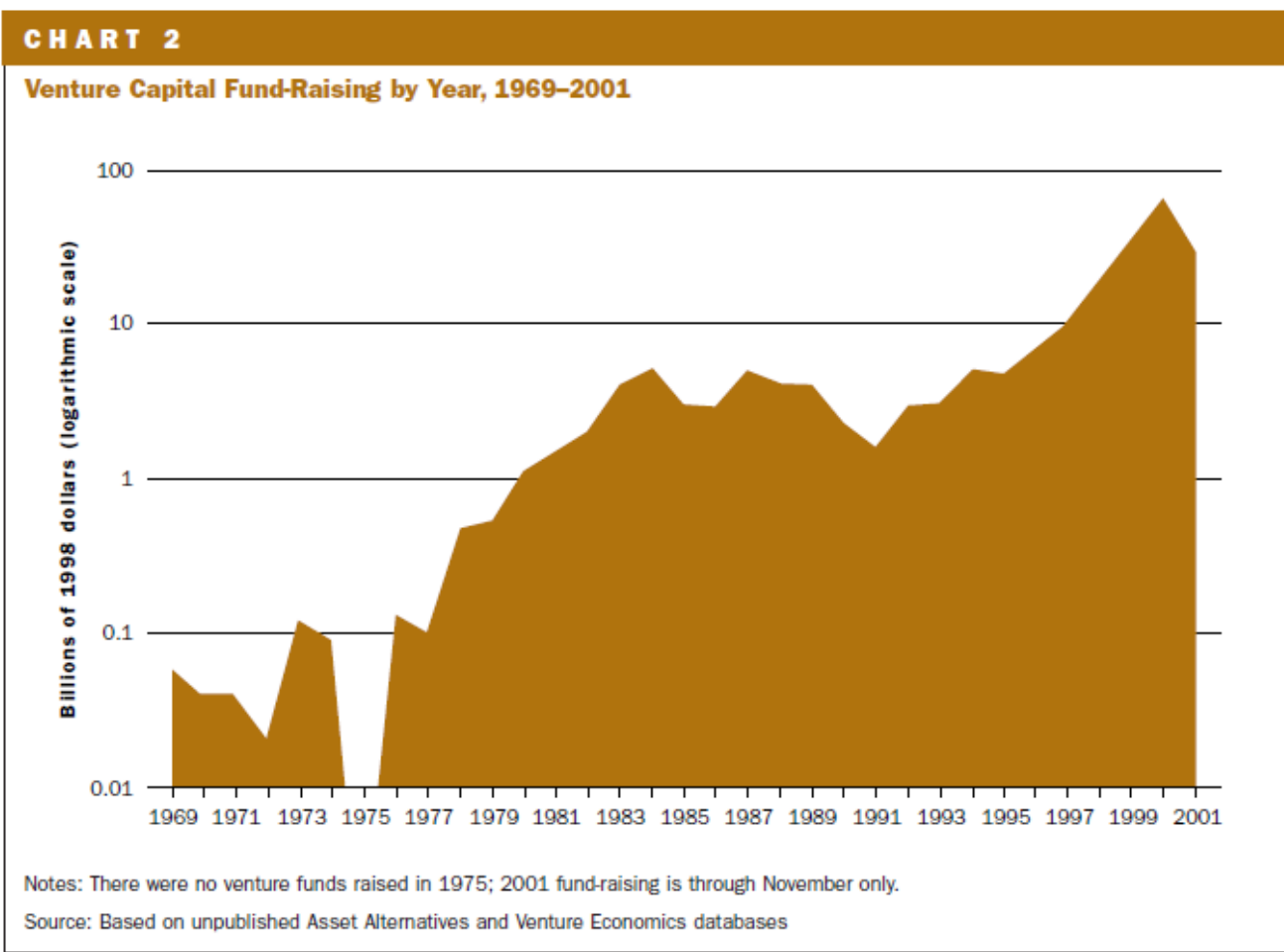

Fig. 4. Venture capital fund raising over time period of 1969 - 2001 (after Lerner (2012)).

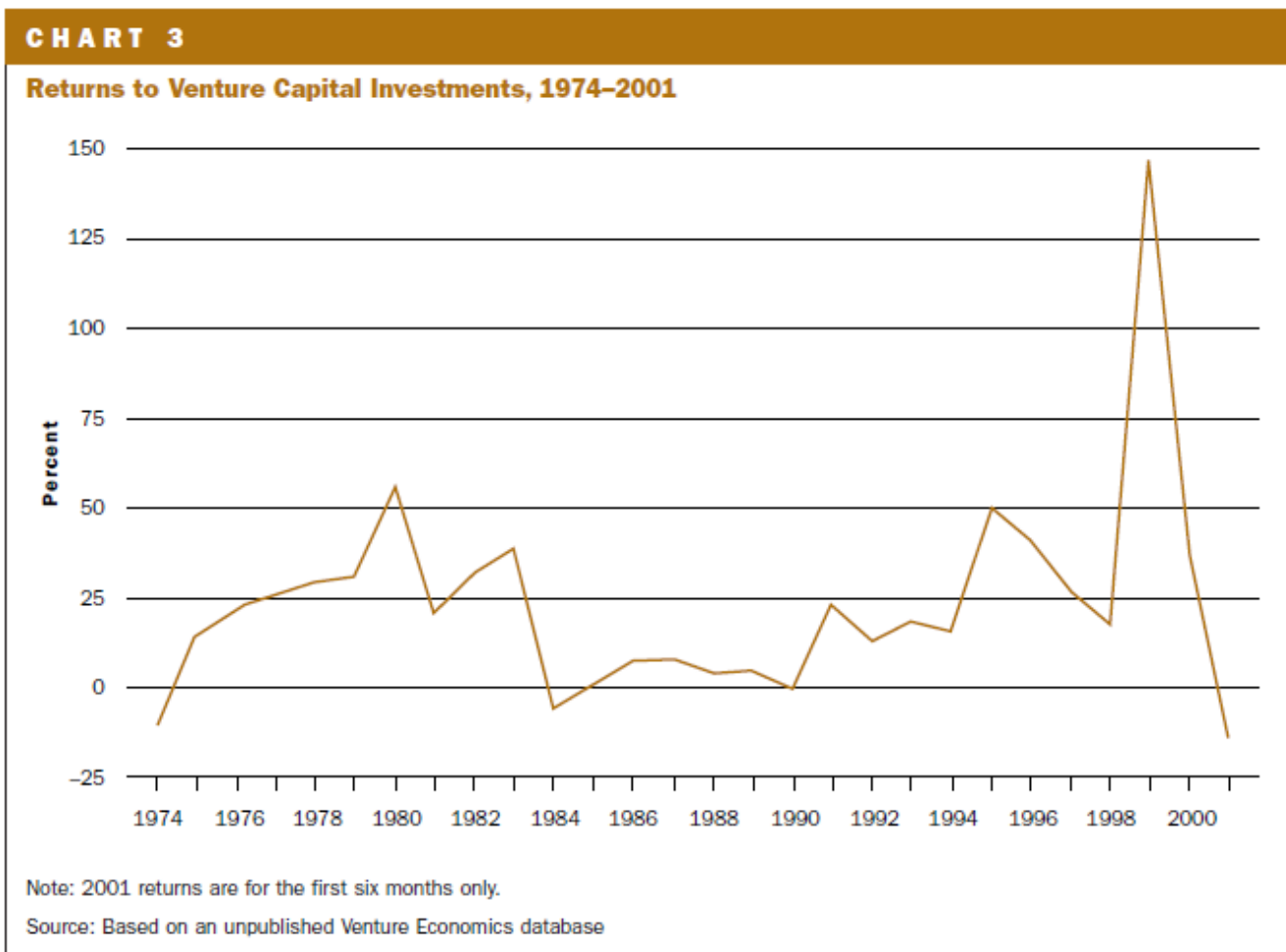

Fig. 5. Returns to venture capital investments in time period of $1974-2001$ (after Lerner (2012)). 


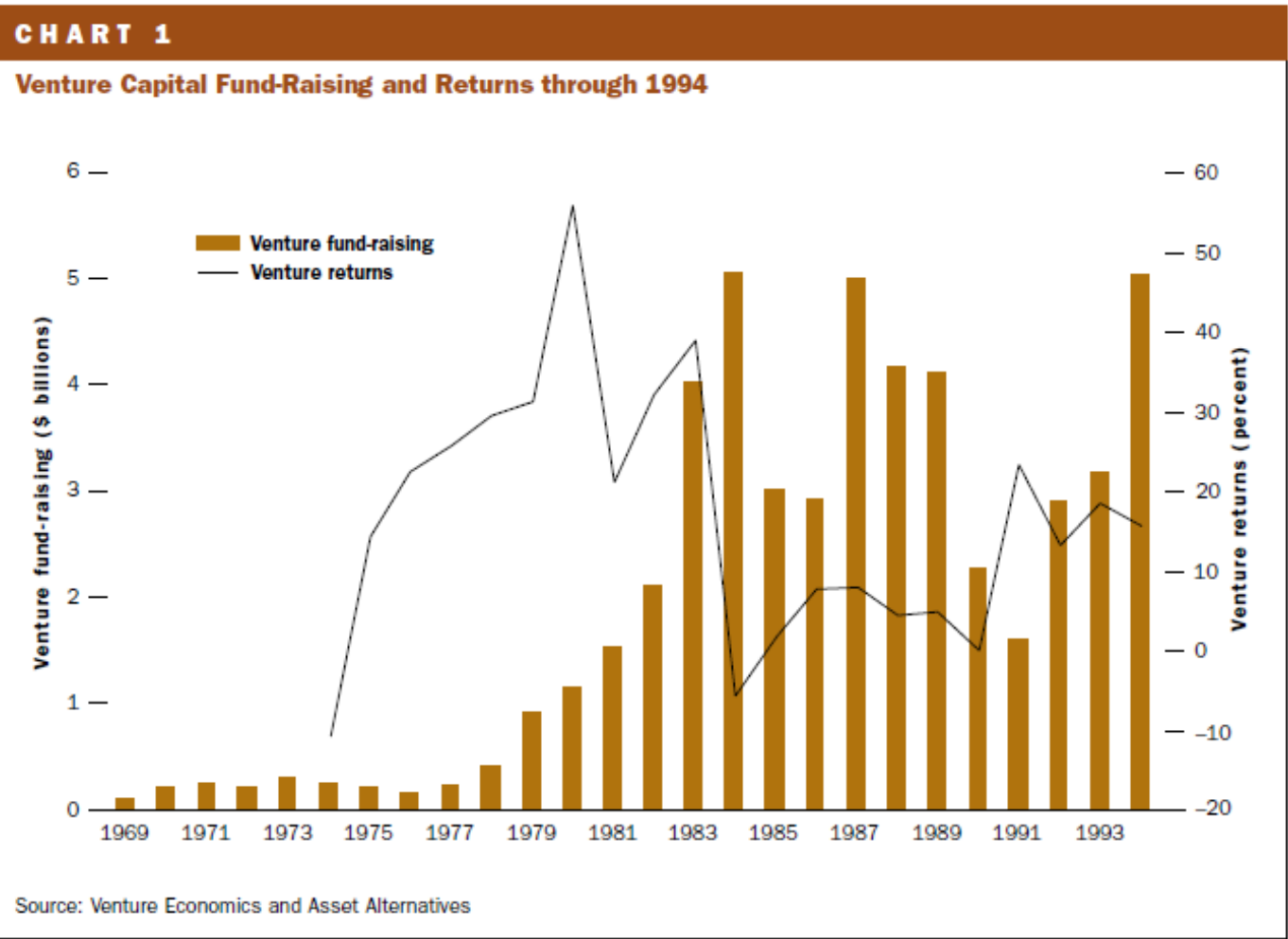

Fig. 6. Venture capital fund - raising and returns through 1969 - 1994 (after Gompers (2002)).

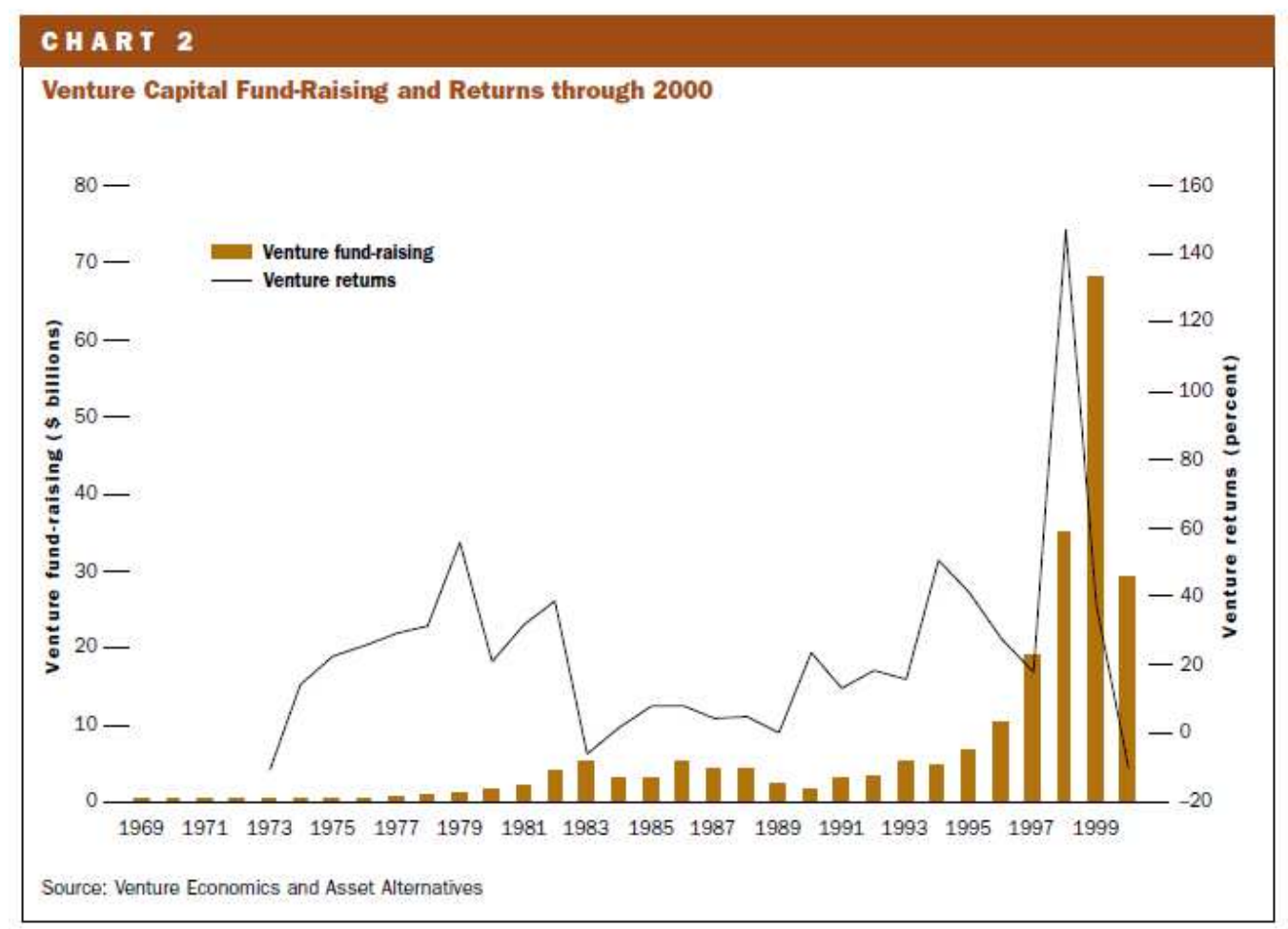

Fig. 7. Venture capital fund - raising and returns through 1969 - 2000 (after Gompers (2002)). 
Fig. 8 shows the total venture capital activity in the United States 1995 - 2005 in Shachmurove $Y$ (2007), and Fig. 9 presents the total number of deals in venture capital investment in the United States in 1995 - 2005 in Shachmurove Y (2007).

Total Venture Capital Investment Activity in the United States 1995 - 2005

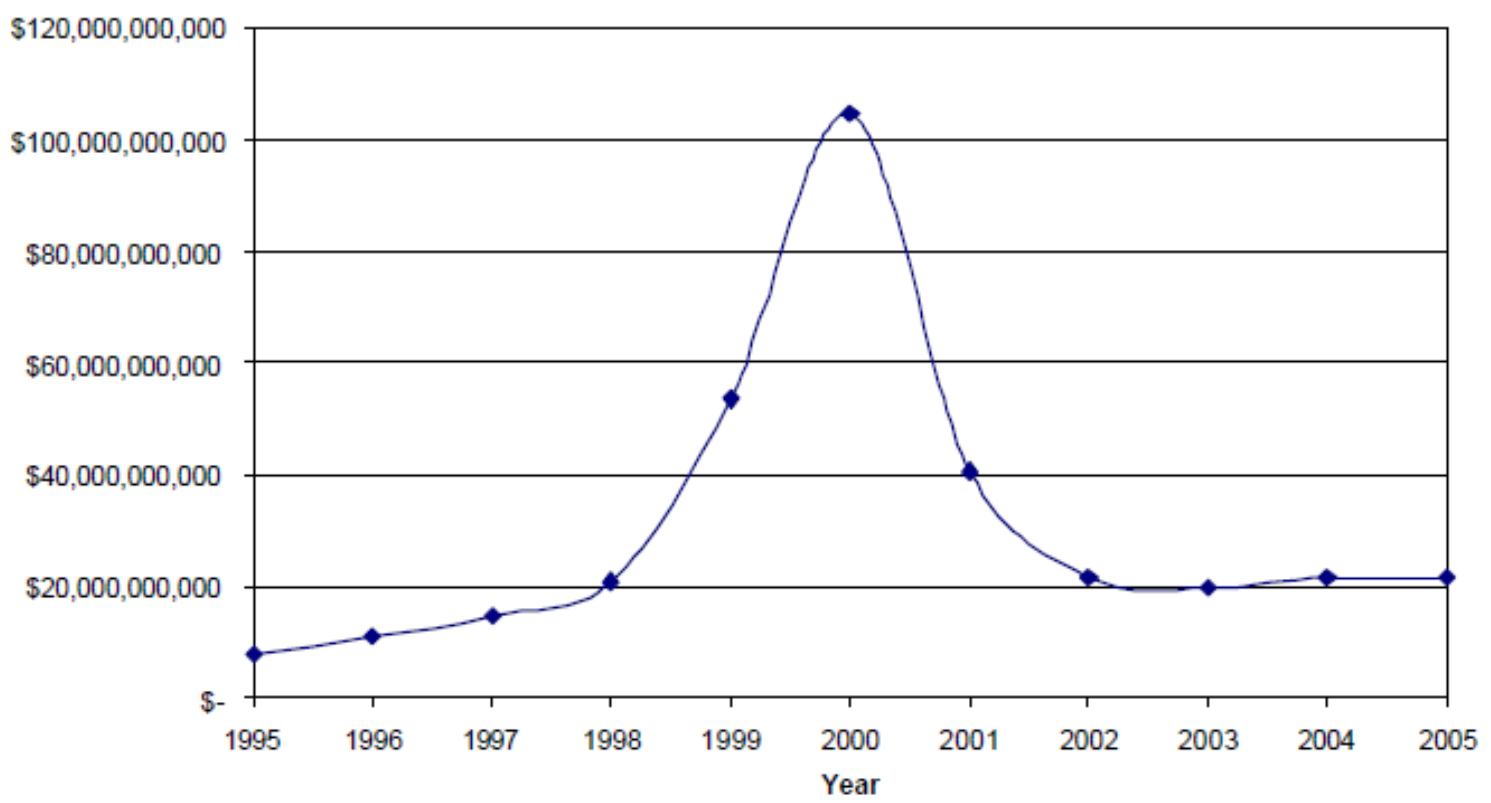

Fig. 8. Total venture capital activity in the United States 1995 - 2005 in Shachmurove Y(2007).

Total Number of Deals USA 1995-2005

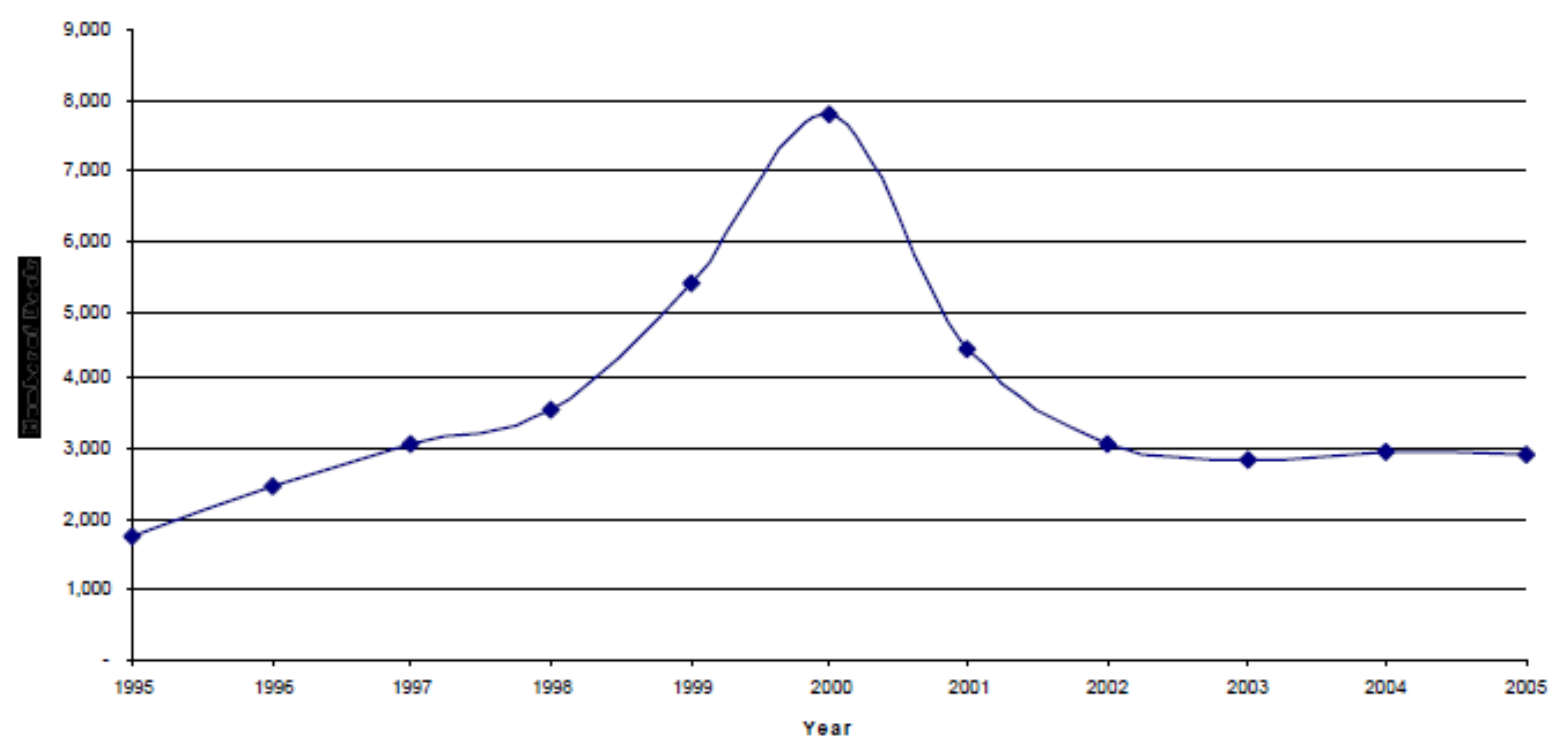

Fig. 9. Total number of deals in venture capital investment in the United States in $1995-2005$ in Shachmurove Y (2007). 
Fig. 10 depicts the venture capital under management by the investor type in Canada in 1992 - 2001 in Cumming, MacIntosh (2003b), and Fig. 11 shows the venture capital funds in Canada in 1988 - 2001 in Cumming, MacIntosh (2003b).

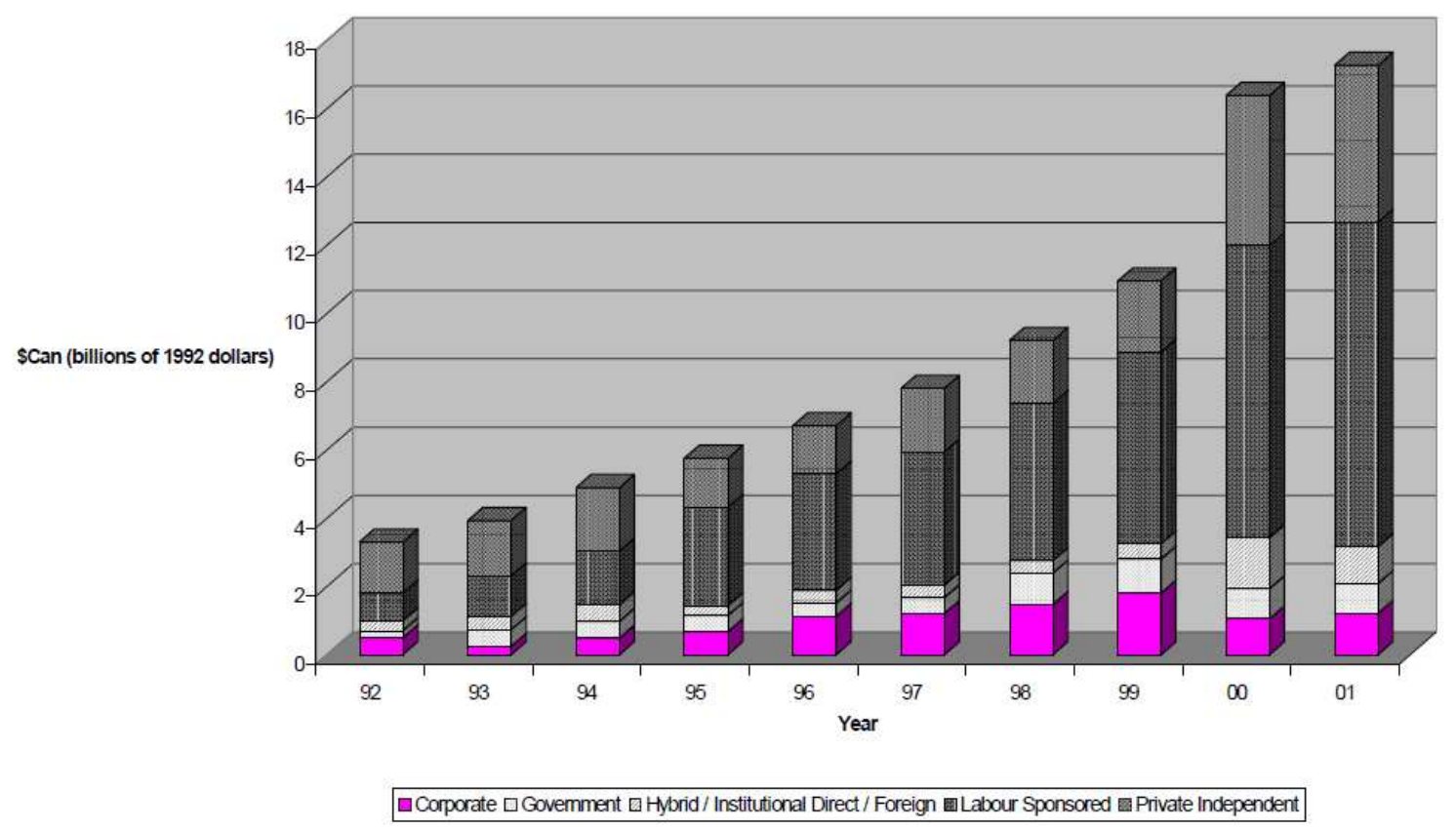

Fig. 10. Venture capital under management by investor type in Canada in 1992 - 2001 (after Cumming, MacIntosh (2003b)).

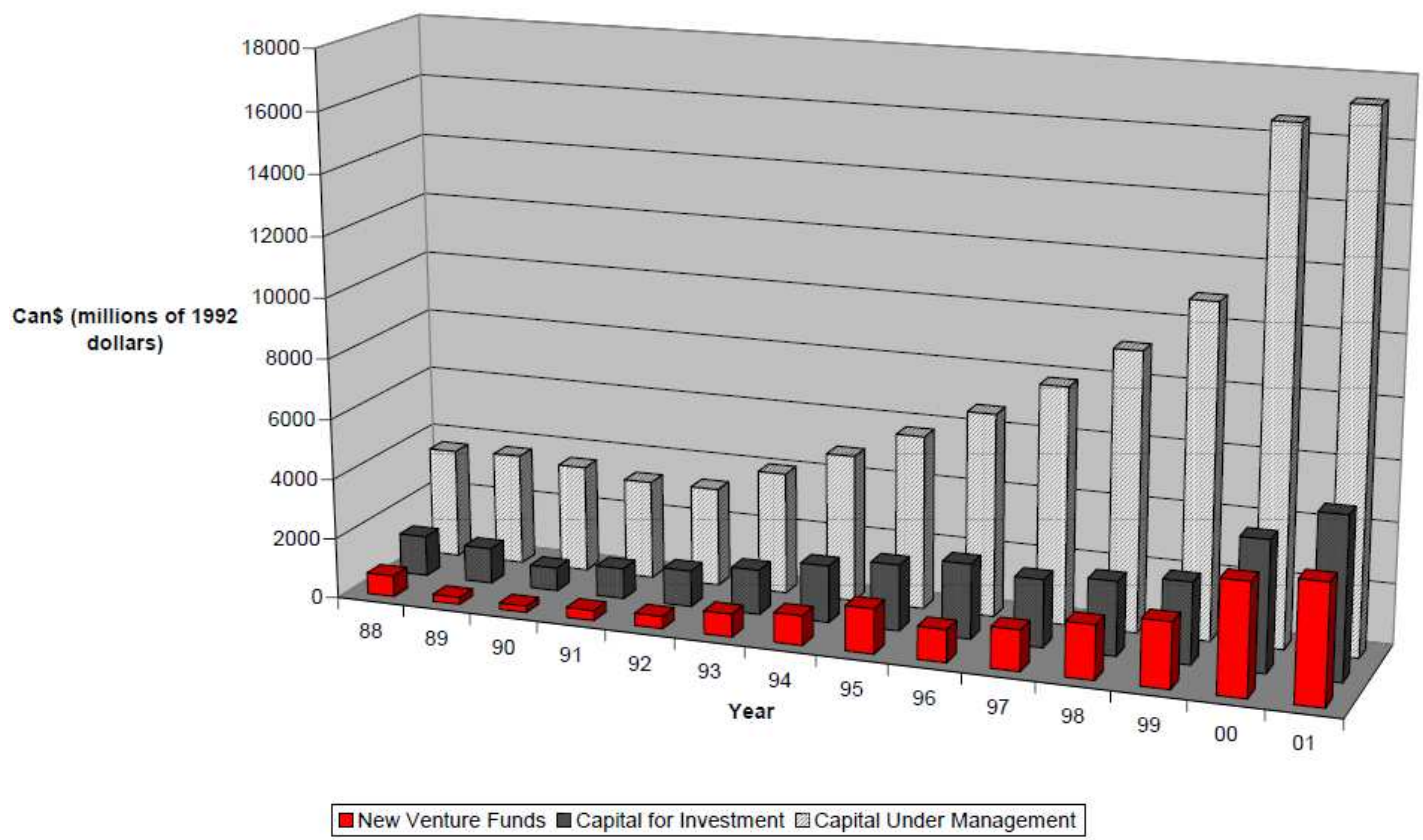

Fig. 11. Venture capital funds in Canada in 1988 - 2001 (after Cumming, MacIntosh (2003b)). 
Fig. 12 shows the stages of venture capital investment in Canada in 1977 - 2001 in Cumming, MacIntosh (2003b), and Fig. 13 provides information on the venture capital exits in Canada in 1991 - 1998 in Cumming, MacIntosh (2003b).

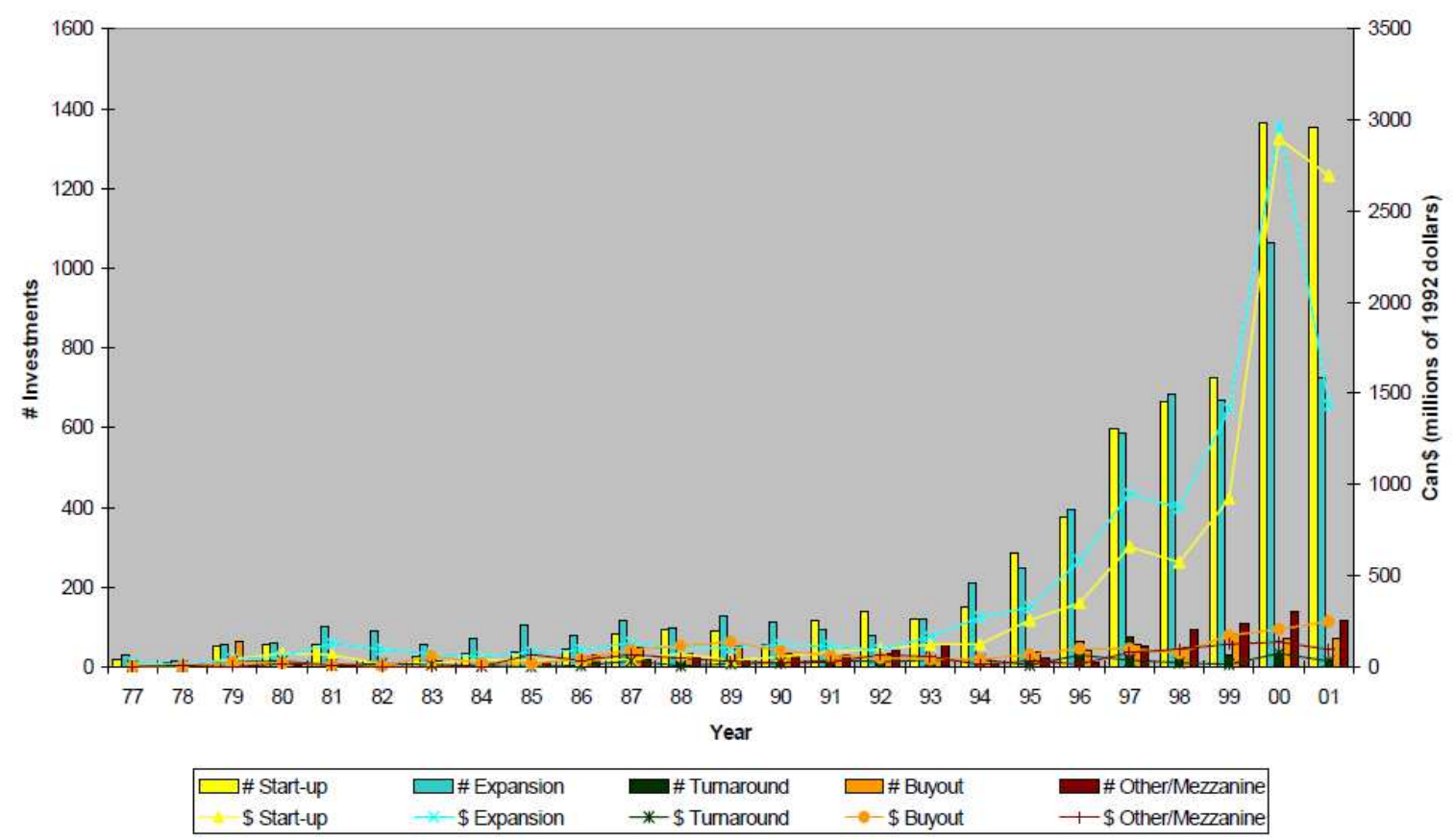

Fig. 12. Stages of venture capital investment in Canada in 1977 - 2001 (after Cumming, MacIntosh (2003b)).

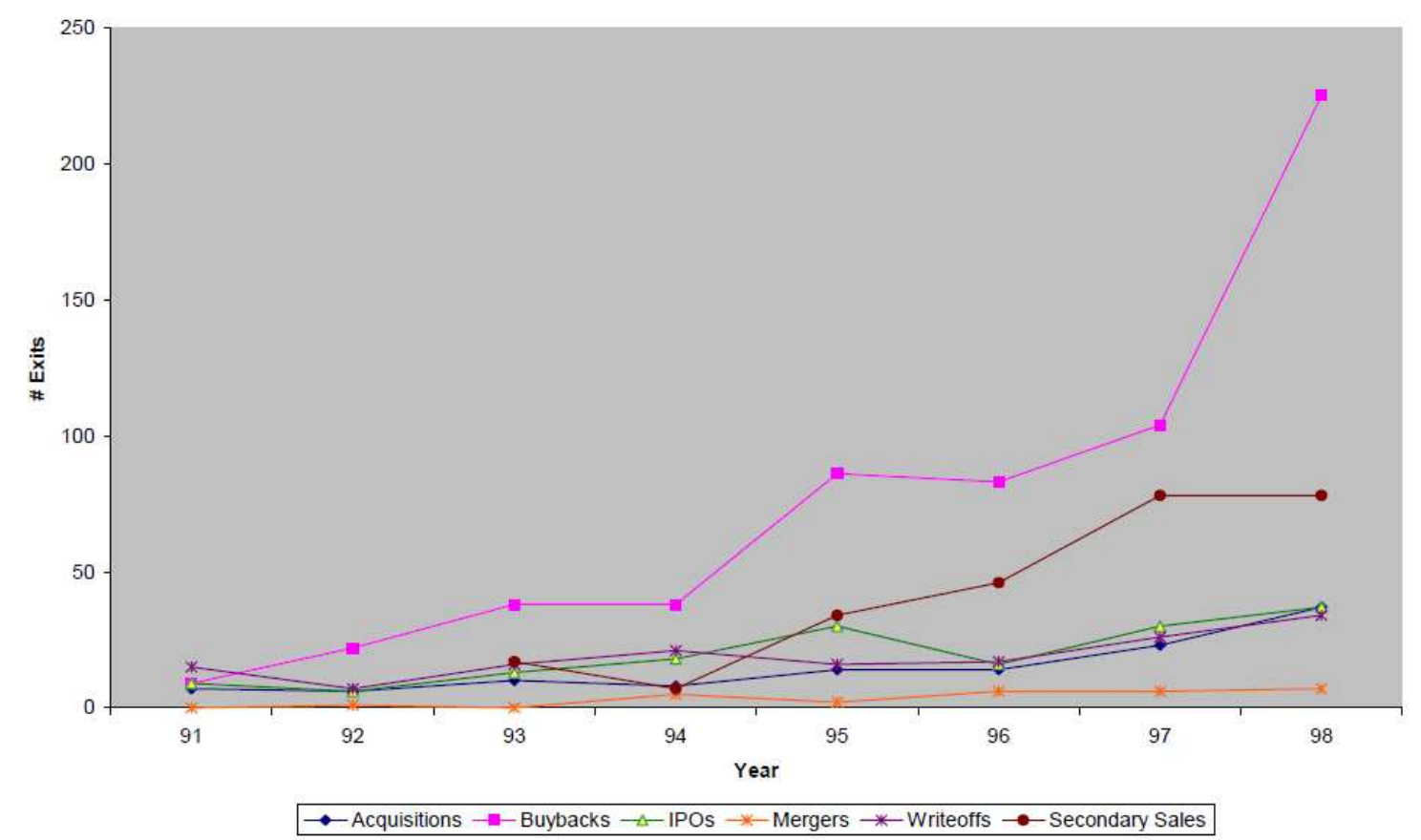

Fig. 13. Venture capital exits in Canada in 1991 - 1998 (after Cumming, MacIntosh (2003b)). 
Let us explain that there is a big number of different $V C$ industry development programs in many countries in Sau (2007): "SBIR (Small Business Innovation Research) and SBIC (Small Business Investment Company) in the USA, the ETF (European Technology Facility), I-TEC (Innovation and Technology Equity Capital) and LIFT (Linking Innovation, Finance and Technology) in the European Union."

Fig. 14 shows the OECD venture capital investment by stages as a share of GDP in 1998 - 2001 in Baygan (2003).

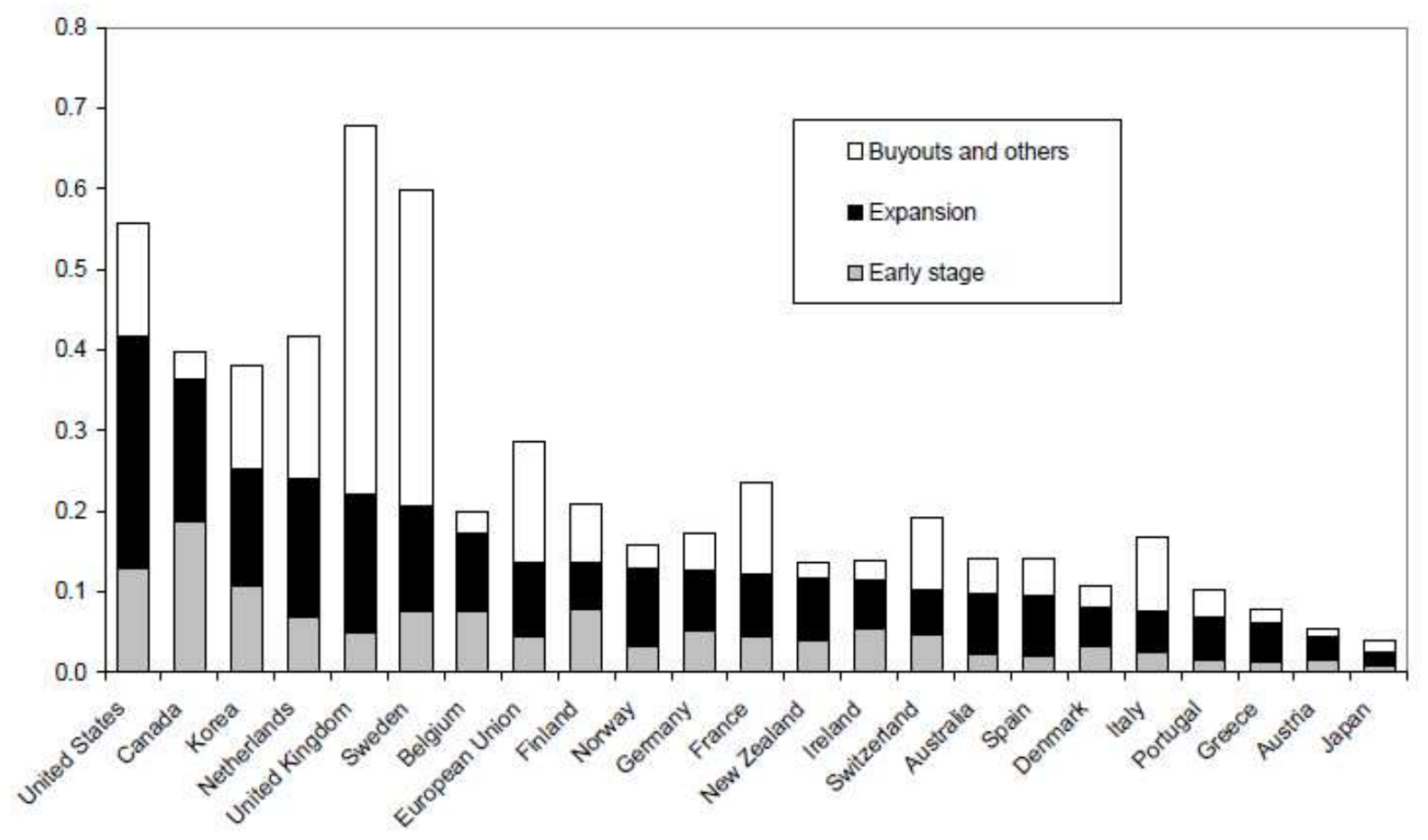

Fig. 14. OECD venture capital investment by stages as a share of GDP, 1998-2001 (after Baygan (2003)).

Da Rin, Nicodano, Sembenelli (2006) point out: "The creation of 'active' venture capital markets, i.e. venture capital markets which provide strong support for early stage and high-tech ventures, has received a high priority by economic policy. As economies become ever more dependent on innovation and entrepreneurship for achieving sustained growth, governments around the world have been trying to replicate the diffusion and success that venture capital has achieved in the United States." Let us add that the creation of the VC market requires the presence of social, scientific, financial and information technology infrastructures. Gvazdaityte (2012) explains: "Literature analysis has shown that the main conditions, needed to create venture capital industry are: appropriate financial market structure, human resources 
availability, source of opportunities, supporting institutions and government policy. As well the collaboration between universities, private companies and governments is essential."

Tab. 1 shows the agents involved in creating venture capital industry in Gvazdaityte (2012).

\begin{tabular}{|c|c|c|}
\hline Agents & Formal functions & Informal functions \\
\hline \multirow[t]{3}{*}{ Universities } & Nurture innovations & Incubate start-ups \\
\hline & Accumulate expertise & Socialize agents \\
\hline & Provide trained workers & \\
\hline \multirow[t]{5}{*}{ Large firms } & Nurture innovations & Incubate start-ups \\
\hline & Develop innovations & Acquire start-ups \\
\hline & Accumulate expertise & Partner with start-ups \\
\hline & & Provide trained workers \\
\hline & & Socialize agents \\
\hline \multirow[t]{2}{*}{ Law firms } & Accumulate legal expertise & Embed start-ups \\
\hline & Handle legal issues & Network the cluster \\
\hline Recruitment agencies & Favor labor market & Network the cluster \\
\hline \multirow{2}{*}{ Media } & Circulate information & Publicize start-ups \\
\hline & & $\begin{array}{l}\text { Sustain an entrepreneurial } \\
\text { culture }\end{array}$ \\
\hline \multirow[t]{2}{*}{ Consulting groups } & $\begin{array}{l}\text { Accumulate business } \\
\text { expertise }\end{array}$ & Provide trained workers \\
\hline & $\begin{array}{l}\text { Supply expertise to start- } \\
\text { ups }\end{array}$ & \\
\hline \multirow[t]{2}{*}{$\begin{array}{l}\text { CPA's (Certified Public } \\
\text { Accountant) }\end{array}$} & $\begin{array}{l}\text { Accumulate accounting } \\
\text { expertise }\end{array}$ & \\
\hline & Handle accounting issues & \\
\hline \multirow[t]{2}{*}{ Investment banks } & Organize IPO of start-ups & Signal start-ups \\
\hline & $\begin{array}{l}\text { Organize acquisitions of } \\
\text { start-ups }\end{array}$ & \\
\hline Commercial banks & $\begin{array}{l}\text { Enable financial } \\
\text { transactions }\end{array}$ & \\
\hline
\end{tabular}

Tab. 1. Agents involved in creating venture capital industry (after Gvazdaityte (2012)).

The modern research projects, aiming to create the extended knowledge base on the venture capital investments, have been conducted by many world renowned scientists: Rind (1981); Tyebjee, Bruno (1981), Bruno, Tyebjee (1983, 1986), Tyebjee, Bruno (1984), Chan (1983), Felda, DeNino, Salter (1983), Wilson (1983); Merkle (1984); Hutt, Thomas (1985), 
MacMillan, Siegel, Narasimha (1985), MacMillan, Zemann, Narasimha (1987); Beatty, Ritter (1986), Nevermann, Falk (1986), Timmons, Bygrave (1986); Block, Ornati (1987), Bygrave (1987), Bygrave, Timmons (1992), Robinson (1987), Ruhnka, Young (1987, 1991), Ruhnka, Felman, Dean (1992), Sandberg, Hofer (1987), Stedler (1987); Brophy, Guthner (1988), Clark (1988), Eisinger (1988, 1993), Florida, Kenney (1988), Florida, Smith (1993), Gladstone (1988), Harris, Raviv (1988), Hofer (1988), MacMillan, Kulow, Khoylian (1988), Sandberg, Schweiger, Schmidt (1988), Siegel R, Siegel E, MacMillan (1988), Tirole (1988); Benveniste, Spindt (1989), Gorman, Sahlman (1989), Holmstrom, Tirole (1989), Poterba (1989a, b); Amit, Glosten, Muller (1990a, b), Amit, Brander, Zott (1998), Barry, Muscarella, Peavy, Vetsuypens (1990), Barry (1994), Chan, Siegel, Thakor (1990), Hisrich, Jankowitz, (1990), Sahlman (1990, 1993), Sykes (1990); Dixon (1991), Megginson, Weiss (1991); Sapienza (1992), Sapienza, Gupta (1994), Sapienza, Manigart, Vermeir (1996); Hall, Hofer (1993), Rosenstein, Bruno, Bygrave, Taylor (1993), Sahlman (1993); Admati, Pfleiderer (1994), Aghion, Tirole (1994), Anton, Yao (1994), Berglöf (1994), Bhidé (1994), Fried, Hisrich (1994), Gompers (1994, 1995, 1996, 1998, 2002, 2007), Gompers, Lerner (1996, 1997, 1998a, b, c, 1999a, b, c, d, 2000a, b, 2001a, b), Brav, Gompers (1997), Baker, Gompers (2003), Brav, Gompers (2003), Gompers, Lerner, Scharfstein (2005), Gompers, Kovner, Lerner, Scharfstein (2006, 2008), Gompers, Kovner, Lerner (2009), Gompers, Lerner, Scharfstein, Kovner (2010), Knight (1994), Kroszner, Rajan (1994), Lerner (1994a, b, 1995a, b, 1998, 1999, 2002, 2008, 2009), Kortum, Lerner (1998, 2000), Lerner, Shane, Tsai (2003), Lerner, Schoar (2004, 2005), Lerner, Moore, Shepherd (2005), Lerner, Schoar, Wongsunwai (2007), Lerner, Sorensen, Strömberg (2009), Chen, Gompers, Kovner, Lerner (2009), Lerner, Tåg (2012), Puri (1994, 1996), Puri, Robinson (2011); Anton, Yao (1995), Elango, Fried, Hisrich, Polonchek (1995), Hart (1995), Jain, Kini (1995), Loughran, Ritter (1995), Willner (1995); Muzyka, Birley, Leleux (1996), Packer (1996), Pettway, Kaneko (1996); Amit, Brander, Zott (1997), Cai, Wei (1997), Chevalier, Ellison (1997), Gilford (1997), Karsai, Wright, Filatotchev (1997), Wright, Robbie, Ennew (1997), Manigart, Wright, Robbie, Desbrieres, De Waele (1997), Manigart, Baeyens, Hyfte (2002), Manigart, De Waele, Wright, Robbie, Desbrieres, Sapienza, Beekman (2000, 2002); Bergemann, Hege (1998), Berger, Udell (1998), Berger, Schaek (2011), Black, Gilson (1998), Cornelius, Isaksson (1998), Fried, Bruton, Hisrich (1998), Gerke (1998), Hellmann (1998, 2000, 2002, 2006, 2007), Hellmann, Puri (2000, 2002), Becker, Hellmann (2005), Hellmann, Lindsey, Puri (2004, 2008), Hyde (1998), Jacobs, Scheffler (1998), Karsai (1998, 2003, 2004), Karsai, Wright, Dudzinski, Morovic (1999), Lin, Smith (1998), Marx (1998), Marx, Strumsky, Fleming (2009), Murray, Marriott (1998), Prowse (1998), Rajan, Zingales (1998), Trester (1998), Wright, Robbie (1998), Zider (1998); Aernoudt 
(1999), Bliss (1999), Bygrave, Hay, Peeters (1999), Gilson (1999), Gilson, Schizer (2002, 2003), Gulati, Gargiulo (1999), Hamao, Packer, Ritter (1999), Leopold (1999), Neher (1999), Shepherd (1999), Shepherd, Zacharakis (1999), Stillman, Sunderland, Heyl, Swart (1999); Baygan, Freudenberg (2000), Baygan (2003), Bharat, Galetovic (2000), Cumming (2000, 2001, 2008), Cumming, MacIntosh (2000, 2001, 2002a, 2002b, 2002c, 2002d, 2003a, b, 2006), Cumming, Fleming (2002), Cumming, Fleming, Schwienbacher (2005, 2006, 2009), Cumming, Fleming, Suchard (2005), Cumming, Johan (2008), Cumming, Walz (2010), Gans, Stern (2000, 2003), Gans, Hsu, Stern (2002), Jain, Kini (2000), Jeng, Wells (2000), Kaplan, Strömberg (2000, 2001, 2002, 2003, 2004, 2009), Kaplan, Schoar (2005), Kaplan, Martel, Strömberg (2007), Kaplan, Sensoy, Strömberg (2009), Kaplan, Lerner (2010), Karä̈merlioğlu, Jacobsson (2000), Koski (2000), Lee (2000), Lehtonen (2000), Quindlen (2000), Schefczyk (2000), Schertler (2000); Bascha, Walz (2001), Engel (2001a, b, 2002); Francis, Hasan (2001), Fredriksen, Klofsten (2001), Hyytinen, Pajarinen (2001), Keuschnigg, Nielsen (2001, 2003a, b, 2004a, b), Keuschnigg (2003, 2004a, b), Kanniainen, Keuschnigg (2004), Kirilenko (2001), Lockett, Wright (2001), Maula, Murray (2001), Peng (2001), Seppä, Laamanen (2001), Seppä (2003), Shachmurove Y (2001, 2007a, b), Shachmurove A, Shachmurove Y (2004), Shachmurove E, Shachmurove Y (2004), Sorenson, Stuart (2001); Allen, Song (2002), Audretsch, Lehmann (2002), Bottazzi, Da Rin (2002a, b, 2004), Bottazzi, Da Rin, Giavazzi (2003), Bottazzi, Da Rin, Hellmann (2004a, b, 2008, 2009), Brander, Amit, Antweiler (2002), Brander, De Bettignies (2009), Brander, Egan, Hellmann (2008), Brander, Du, Hellmann (2010), Chesbrough (2002), Cestone (2002), Davis, Schachermayer, Tompkins (2002), Dossani, Kenney (2002), Kenney, Han, Tanaka (2002), Eisele, Habermann, Oesterle (2002), Everts (2002), Koh F C C, Koh W T H (2002), McGlue (2002), Moskowitz, Vissing-Jørgensen (2002), Shane, Cable (2002), Shane, Stuart (2002), Zook (2002); Becker, Hellman (2003), Bergemann, Hege (2003), Hege, Palomino, Schwienbacher (2009), Casamatta (2003), Casamatta, Haritchabalet (2007), Cornelli, Yosha (2003), Davila, Foster, Gupta (2003), Franzke, Grohs, Laux (2003), Gawlik, Teczke (2003), Gilson, Schizer (2003), Hirukawa, Ueda (2003), Inderst, Muller (2003), Keilbach, Engel (2003), Leleux, Surlemont (2003), Rindermann (2003), Schertler (2003), Schmidt (2003), Schmidt, Wahrenburg (2003), Stuart, Sorenson (2003), Wang C K, Wang K, Lu (2003), Wasserman (2003, 2006), Woodward, Hall (2003); Aghion, Bolton, Tirole (2004), Avnimelech, Kenney, Teubal (2004), Avnimelech, Teubal (2004), Baum, Silverman (2004), Berk, Green, Naik (2004), Da Rin, Nicodano, Dittmann, Maug, Kemper (2004), Hsu (2004), Inderst, Müller (2004, 2009), Inderst, Müller, Muennich (2007), Jones, Rhodes-Kropf (2004), Lee, Wahal (2004), Megginson (2004), Michelacci, Suarez (2004), Mishra (2004), Peggy, Wahal (2004), Repullo, Suarez (2004), 
Roman, van Pottelsberghe de la Potterie (2004), Sembenelli (2004), Sternberg (2004), Ueda (2004); Bergemann, Hege (2005), Cochrane (2005), Da Rin, Hege, Llobet, Walz (2005), Da Rin, Nicodano, Sembenelli (2005, 2006), Da Rin, Hellmann, Puri (2011), De Carvalho, Calomiris, De Matos (2005), Dessein (2005), Dessí (2005), Dimov, Shepherd (2005), Dushnitsky, Lenox (2005, 2006), Dushnitsky, Lavie (2008), Ernst, Witt, Brachtendorf (2005), Ge, Mahoney J M, Mahoney J T (2005), Hsu, Kenney (2005), Hsu (2006, 2007), Klepper, Sleeper (2005), Klepper, Thompson (2010), Kõomägi (2005a, b, c), Kõomägi, Sander (2006), Lai (2005, 2007), Mäkelä, Maula (2005), Mayer, Schoors, Yafeh (2005), Mayer, Schoors, Yafeh (2005), Neus, Walz (2005), Wong (2005), Zook (2005); Antonelli, Teubal (2006), Cassiman, Ueda (2006), Colombo, Dimov, De Clercq (2006), Eckhardt, Shane, Delmar (2006), Ellul, Pagano (2006), Gebhardt, Schmidt (2006), Grilli, Piva (2006), Fallick, Fleischman, Rebitzer (2006), Franco, Filson (2006), Franco, Mitchell (2008), Isaksson (2006), Mathews (2006), Motohashi (2006, 2010), Nielsen, Keuschnigg (2006), Proimos, Murray (2006), Riyanto, Schwienbacher (2006), Wadhwa, Kotha (2006), Zhang (2006, 2007a, b); Bernile, Cumming, Lyandres (2007), Campbell, Kraeussl (2007), Colombo, Dawid, Kabus (2007), de Bettignies, Brander (2007), de Bettignies, Chemla (2008), de Bettignies (2008), Engel, Keilbach (2007), Hochberg, Ljungqvist, Lu (2007, 2010), Hsu (2007), Jovanovic, Szentes (2007), Lai (2007), Li, Prabhala (2007), Luukkonen (2007, 2008), Mann, Sager (2007), Pintado, De Lema, Van Auken (2007), Robinson, Stuart (2007), Sau (2007), Schwienbacher (2007, 2008), Sørensen (2007), Tykvová (2007); Aizenman, Kendall (2008), Broughman (2008), Broughman, Fried (2010), Davidsson, Steffens, Gordon, Senyard (2008), Geronikolaou, Papachristou (2008), Hand (2008), Hirukawa, Ueda (2008a, b), Katila, Rosenberger, Eisenhardt (2008), Lindsey (2008), McMillan, Roberts, Livada, Wang (2008), Orman (2008), Rossetto (2008), Schwienbacher (2008, 2009), Sorenson, Stuart (2008), Winton, Yerramilli (2008), Nahata (2008), Phalippou (2008), Phalippou, Gottschalg (2009), Puri, Zarutskie (2008), Van Deventer, Mlambo (2008, 2009); Aberman (2009), Bengtsson, Ravid (2009), Bengtsson, Hand (2011), Bengtsson, Sensoy (2011), Block, Sandner (2009), Clarysse, Knockaert, Wright (2009), Cockburn, MacGarvie (2009), Duffner, Schmid, Zimmermann (2009), Fitza, Matusik, Mosakowski (2009), Fulghieri, Sevilir (2009a, b), Jones, Mlambo (2009), Krohmer, Lauterbach, Calanog (2009), Lingelbach, Murray, Gilbert (2009), Litvak (2009a, b), Masulis, Nahata (2009, 2011), Norbäck, Persson (2009), Samuelsson, Davidsson (2009), Van de Vrande, Vanhaverbeke, Duysters (2009); Arikawa, Imad'eddine (2010), Benson, Ziedonis (2010), Bienz, Walz (2010), Cantner, Stützer (2010), Cowling, Murray, Liu (2010), Dushnitsky, Shapira (2010), Elston, Yang (2010), Groh, Liechtenstein (2010), Hall, Woodward (2010), Inci, Barlo (2010), Ivanov, Xie (2010), Jegadeesh, Kräussl, Pollet (2010), Korteweg, Sørensen (2010), 
Metrick, Yasuda (2010, 2011), Obschonka, Silbereisen, Schmitt-Rodermund, StuetzerNascent (2010), Samila, Sorenson (2010, 2011), Sevilir (2010), Zarutskie (2010), Zacharakis, Erikson, George (2010); Ball, Chiu, Smith (2011), Cherif, Gazdar (2011), Das, Jo, Kim (2011), Ferretti, Meles (2011), Kandel, Leshchinskii, Kraeussl, Krause (2011), Kerr, Nanda (2011), Li, Abrahamsson (2011), Samila, Sorenson (2011), Tian (2011), Yuklea (2011); Diaconu (2012), Gvazdaityte (2012), Lazarevski, Mrsik, Smokvarski (2012), Lim, Cu (2012), Pommet (2012), Rosenbusch, Brinckmann, Müller (2012), Yitshaki (2012); Alqatawni (2013), Brettel, Mauer, Appelhoff (2013), Pennacchio (2013), Stuetzer, Obschonka, Davidsson, Schmitt-Rodermund (2013), Stuetzer, Obschonka, Schmitt-Rodermund (2013).

\section{Venture capital optimal investment portfolio strategies in highly volatile global capital markets with nonlinearities}

Let us begin with the formulation of the innovative start-ups financing problem in the frames of the theory of corporate finance in Tirole (2006). The main three problems in the startups funding are outlined in Orman (2008):

1. "First, specialized research ventures require substantial upfront resources but do not generate cash flows for a long time.

2. Second, research ventures are typically surrounded by substantial uncertainty concerning their potential outcomes.

3. Finally, most of the assets of a research venture is intangible and hence cannot be used as collateral.

All of these issues potentially reduce the willingness of suppliers of capital to provide financing to such ventures. In extreme situations, these difficulties may even cause creditrationing in Stiglitz and Weiss (1981)."

The $V C$ financing represents a possible solution for the above mentioned financial problems in the cases of innovative start-up companies. There are a number of different investment stages in the venture capital financing. Therefore, let us provide some information on the different VC financing stages in the process of the innovative startup company development in Geronikolaou, Papachristou (2008): “European Venture Capital Association's (EVCA) terminology split $V C$ into three stages namely,

1. Seed finance (intended for new firms in order to evaluate their initial concept),

2. Start-up finance (aiming at the development of the firm's product before the firm has sold any products), and 
3. Expansion finance (aiming to assist the growth and expansion of the firm)."

Sau (2007) proposes a general scheme of the most innovative start-ups financing:

1. Insider capital, informal private equity and easy-term public financing (Seed);

2. Venture capital financing (Start-up);

3. Self-financing, bank and/or business credit (Early Growth);

4. $\quad$ Direct issue of bonds and public equity (Sustained Growth).

Gompers (2002) distinguishes a few investment stages in the innovative startup company:

1. Start-up: Company with a skeletal business plan, product, or service development in preliminary stages.

2. Development: Stage at which product or service development is under way but the company is not generating revenues from sales.

3. Beta: For companies specializing in information technology, the phase at which the product is being tested by a limited number of customers but not available for broad sale. For life sciences companies, beta is synonymous with a drug in human clinical trials or a device being tested.

4. Shipping: The stage at which the product or service is being sold to customers and the company is deriving revenues from those sales but expenses still exceed revenues.

5. Profitable: The stage at which the company is selling products or services and the sales revenue yields a positive net income.

6. Restart: The stage at which the firm is recapitalized at a reduced valuation, accompanied by a substantial shift in the product or marketing focus.

Van Deventer, Mlambo (2008, 2009) write: "There have been several studies done trying to identify the different stages and criteria of the decision-making process. Studies on the processes and criteria used by venture capitalists have been done by Tyebjee and Bruno (1984), MacMillan et al. (1985; 1987), Fried and Hisrich (1994), Shepherd (1999), Kaplan and Strömberg (2003), Kakati (2003), Ge et al. (2005) and Pintado, De Lema and Van Auken (2007). According to Larsson and Roosvall (2000:4), the process is generally conducted in such a way that new ventures must first pass an initial screening, which is typically a review of the business plan. "This is then followed by meetings, a due diligence phase and negotiations around the more detailed issues regarding the investment."'"

Fig. 15 shows the general VC financing scheme in Eisele, Habermann, Oesterle (2002). 


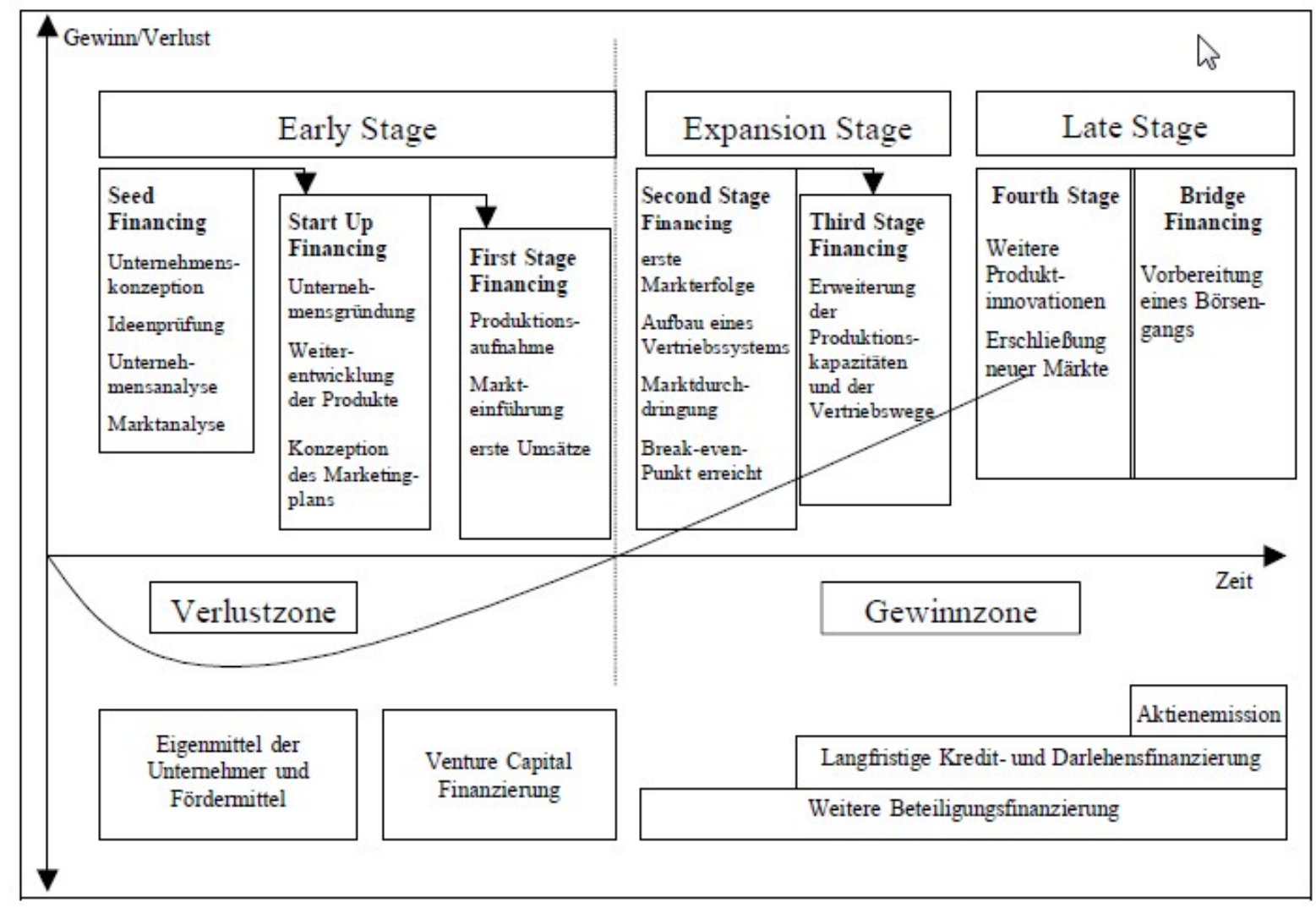

Fig. 15. Venture capital financing scheme (after Eisele, Habermann, Oesterle (2002)).

In the process of the optimal $V C$ investment portfolio selection, the $V C$ firms complete a number of important tasks in Keilbach, Engel (2003): “...Venture capital firms screen potential portfolio firms to select out those with the best growth perspectives. The innovative potential (as signalled by patent applications and by the founders' education levels) play an important role in that respect. This screening process is very selective though successful since venture capital funded firms display indeed higher (twice as large) growth rate as compared to firms of a control group. This stronger growth rate seems to be a result of a commercialization of previous innovations since innovation outputs of venture funded firms do not differ from non venture funded but otherwise strongly similar group of firms of a control group. A plausible explanation for this finding could be that venture capital investors assist their portfolio firms in this commercialization effort, rather than in further innovation effort, in an attempt to maximize sales, hence value, of their portfolio firms. Commercialization is probably done by financial means but also by means of management assistance."

There are several criteria, which can be classified into the two groups such as the important criteria and the unimportant criteria in the process of the decision making on the $V C$ financing. Tab. 2 presents the criteria rated as important by participating VCs, and Tab. 3 shows the criteria rated as not important by participating VCs in Van Deventer, Mlambo (2008, 2009). 


\begin{tabular}{l|c|l|l}
\hline Criterion & Mean & Std. Der. & \multicolumn{1}{|c}{ Category } \\
\hline The entrepreneur is honest and has integrity & 4,9091 & 0,3015 & Management \\
\hline A good market acceptance for the product or service is expected & 4,9091 & 0,3015 & Product \\
\hline The venture will provide a high internal rate of return (IRR) & 4,9091 & 0,3015 & Financial \\
\hline There is a market need for the product or service & 4,8182 & 0,4045 & Market \\
\hline The entrepreneur has a great desire for success & 4,7273 & 0,4671 & Management \\
\hline The product/service has a competitive advantage over competing products & 4,7273 & 0,4671 & Product \\
\hline The venture has high valuation projections & 4,7273 & 0,4671 & Financial \\
\hline There is potential for market growth & 4,7273 & 0,4671 & Market \\
\hline The venture has significant potential for earnings growth & 4,6364 & 0,5045 & Financial \\
\hline The entrepreneur has excellent management skills/experience & 4,5455 & 0,5222 & Management \\
\hline The entrepreneur is hardworking and flexible & 4,5455 & 0,5222 & Management \\
\hline The entrepreneur has good leadership ability & 4,4545 & 0,5222 & Management \\
\hline The market is big & 4,4545 & 0,6876 & Market \\
\hline The entrepreneur has good risk management qualities & 4,3636 & 0,6742 & Management \\
\hline The venture has high profit margin projections & 4,2727 & 0,7862 & Financial \\
\hline The entrepreneur has a good track record & 4,2727 & 0,6467 & Management \\
\hline The entrepreneur has good knowledge of the sector & 4,1818 & 1,4709 & Management \\
\hline The entrepreneur is capable of intense, sustained effort & 4,1818 & 0,6030 & Management \\
\hline The venture will provide a high absolute return & 4,1818 & 0,6030 & Financial \\
\hline The product/service has open access to the market & 4,1818 & 0,7508 & Market \\
\hline The references of the entrepreneur are reputable & 4,0909 & 0,9439 & Management \\
\hline
\end{tabular}

Tab. 2. Criteria rated as important by participating VCs

(after Van Deventer, Mlambo (2008, 2009)).

\begin{tabular}{|c|c|c|c|}
\hline Criterion & Mean & Std. Dev. & Category \\
\hline There will be a tax benefit in financing the venture & 1,9091 & 0,7006 & Financial \\
\hline There will be no follow up investment required & 2,0909 & 1,3004 & Financial \\
\hline The venture will require low monitoring and administration costs & 2,0909 & 1,3004 & Financial \\
\hline The venture has BEE status & 2,3636 & 1,2863 & Other \\
\hline The venture will operate in a non-competitive industry & 2,4545 & 1,0357 & Market \\
\hline The venture will require low marketing and production costs & 2,6364 & 1,1201 & Financial \\
\hline The venture will create a new market & 2,6364 & 0,9244 & Market \\
\hline Product/service is in an early stage of life cycle & 2,7273 & 1,7373 & Product \\
\hline The venture has low overall capital requirements & 2,7273 & 1,1037 & Financial \\
\hline The venture has production capabilities in place & 2,8182 & 1,3280 & Product \\
\hline
\end{tabular}

Tab. 3. Criteria rated as not important by participating VCs

(after Van Deventer, Mlambo (2008, 2009)). 
Fig. 16 shows the venture capital decision-making process in Kõomägi, Sander (2006), and Fig. 17 depicts the quantitative decision-making process among venture capitalists in Estonia in Kõomägi, Sander (2006).

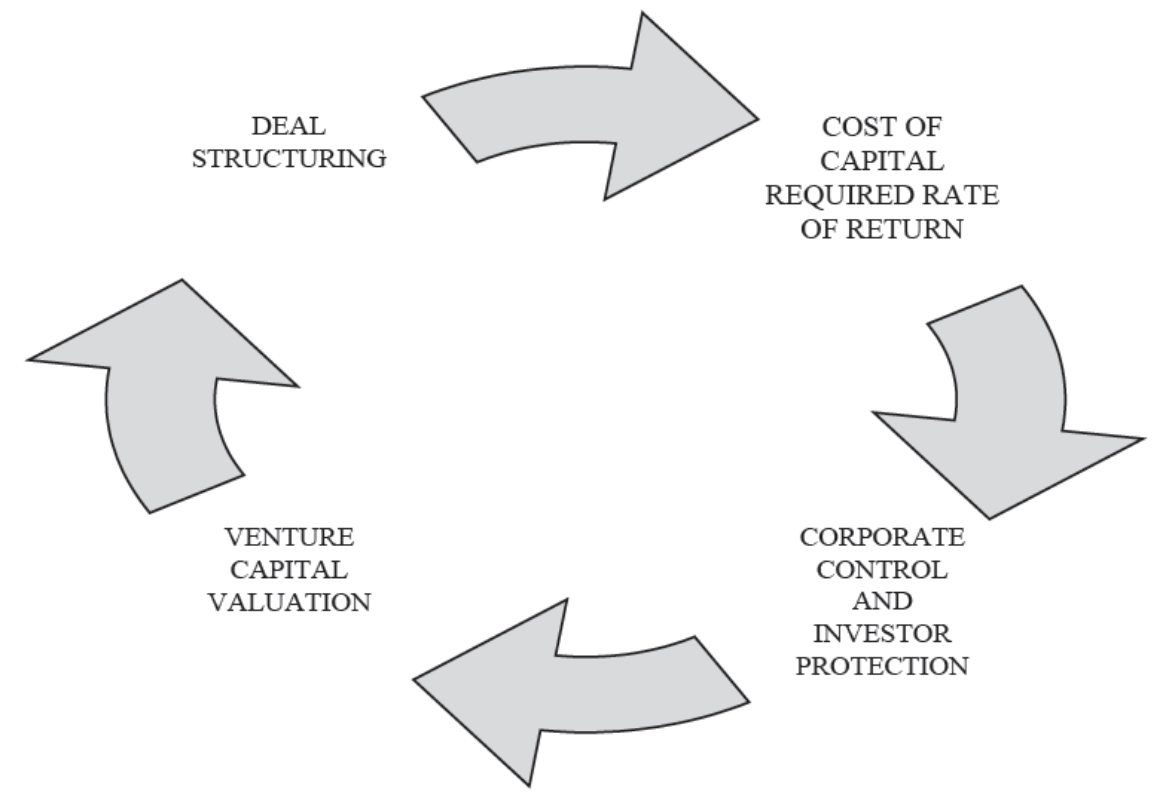

Fig. 16. Venture capital decision-making process (after Kõomägi, Sander (2006)).

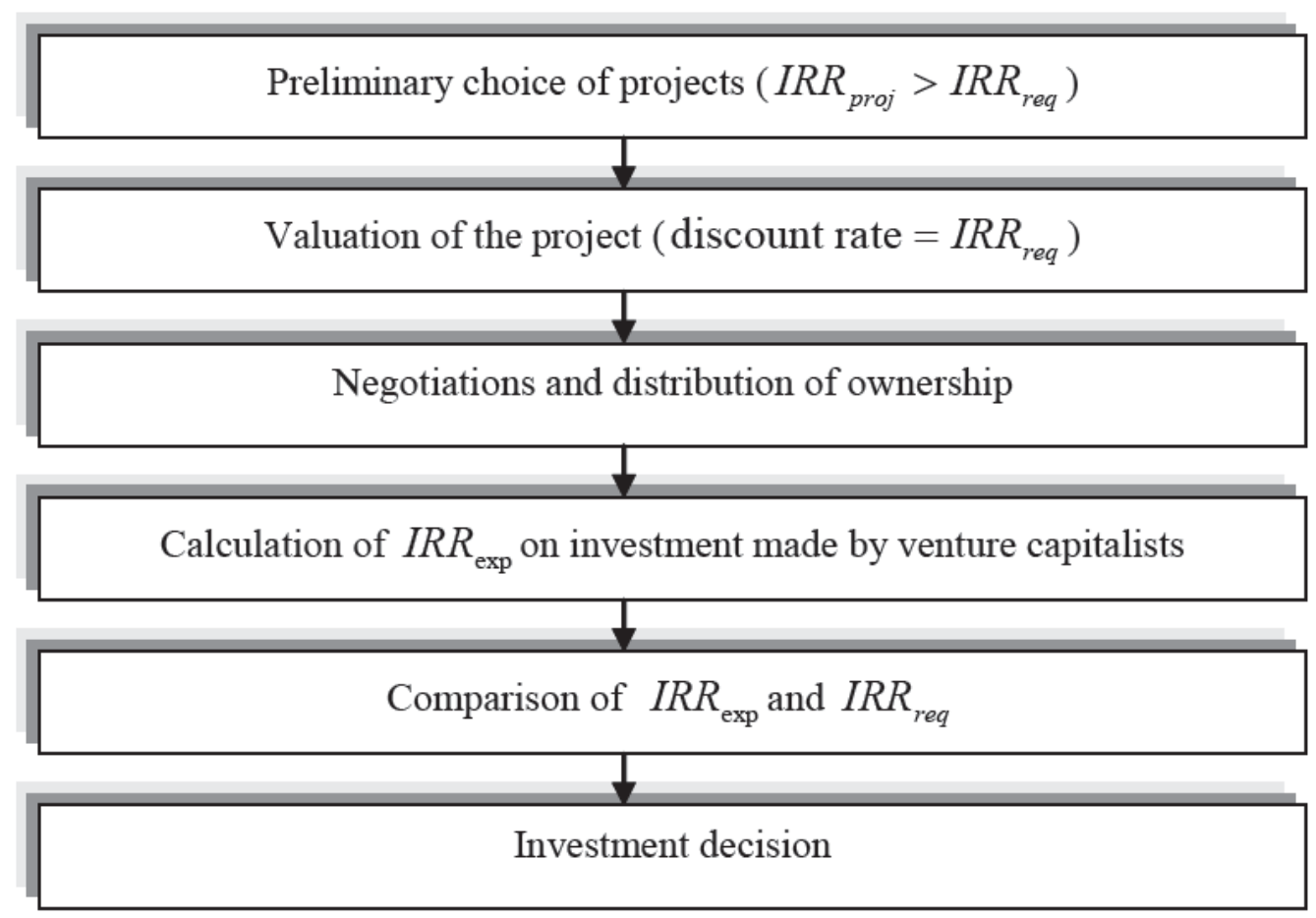

Fig. 17. The quantitative decision-making process among venture capitalists in Estonia (after Kõomägi, Sander (2006)). 
The necessary and sufficient condition for the startup firm to obtain the financing from the uninformed investors is in Da Rin, Nicodano, Sembenelli (2005)

$$
\gamma(\boldsymbol{I}-\boldsymbol{A}) \leq \boldsymbol{p}_{H} \boldsymbol{R}_{u}=\boldsymbol{p}_{H}\left[\boldsymbol{R}-\left(\frac{\boldsymbol{B}}{\boldsymbol{p}_{H}-\boldsymbol{p}_{L}}\right)\right],
$$

where $\boldsymbol{I}$ is the cost of the investment, $\boldsymbol{A}$ is the firm's own equity capital which is pledged as collateral, $\boldsymbol{I}-\boldsymbol{A}>\boldsymbol{O}$ is the amount of capital, which is necessary to borrow for the firm, $\boldsymbol{p}_{\boldsymbol{H}}$ is the probability to deliver the return $\boldsymbol{R}, \boldsymbol{B}$ denotes the private benefits for the entrepreneurs, $\boldsymbol{R}_{\boldsymbol{u}}=\boldsymbol{R}-\boldsymbol{R}_{\boldsymbol{f}}$ is the share of return to uninformed investors, $\boldsymbol{R}_{f}$ is the share of return, retained by the firm.

Therefore, the market value of the loan (the left hand side) cannot exceed the firm's expected income (the right-hand side). Firms are then able to raise finance from uninformed investors if and only if in Da Rin, Nicodano, Sembenelli (2005)

$$
\boldsymbol{A} \geq \overline{\boldsymbol{A}}(\gamma)=\boldsymbol{I}-\left(\frac{\boldsymbol{p}_{\boldsymbol{H}}}{\gamma}\right)\left[\boldsymbol{R}-\left(\frac{B}{\boldsymbol{p}_{H}-\boldsymbol{p}_{L}}\right)\right],
$$

where $\boldsymbol{A}$ is increasing in $\gamma$.

The amount of funds borrowed by monitored firms $I_{v c}$ adjusts to satisfy the incentive compatibility constraint of the venture capitalist in Da Rin, Nicodano, Sembenelli (2005)

$$
I_{v c}(\beta) \geq \frac{c p_{H}}{\beta\left(p_{H}-p_{L}\right)}
$$

where $\beta$ is the rate of return to venture capital, $\beta=\boldsymbol{p}_{\boldsymbol{H}} \boldsymbol{R}_{v c} / \boldsymbol{I}_{v c}$.

The necessary and sufficient condition for a firm to be financed by both uninformed investors and venture capitalists is then in Da Rin, Nicodano, Sembenelli (2005)

$$
\boldsymbol{A} \geq \underline{\boldsymbol{A}}(\gamma, \beta)=\boldsymbol{I}-\boldsymbol{I}_{v c}(\beta)-\left(\frac{\boldsymbol{p}_{\boldsymbol{H}}}{\gamma}\right)\left[\boldsymbol{R}-\left(\frac{\boldsymbol{b}+\boldsymbol{c}}{\boldsymbol{p}_{\boldsymbol{H}}-\boldsymbol{p}_{L}}\right)\right]
$$

where $c$ is the monitoring cost.

Fig. 18 shows the firm's financing choices, depending on their own equity capital in $\mathrm{Da}$ Rin, Nicodano, Sembenelli (2005).

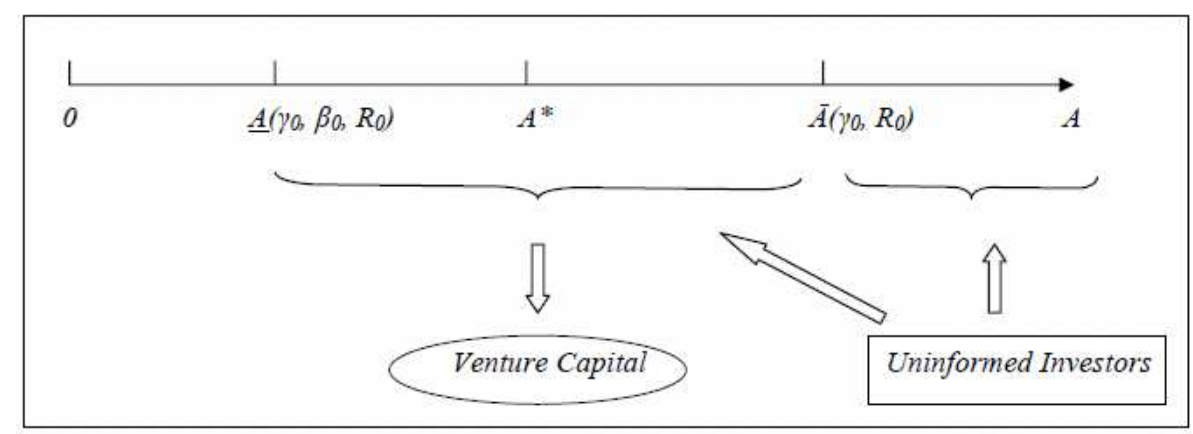

Fig. 18. Firm's financing choice as a function of their equity capital, A (after in Da Rin, Nicodano, Sembenelli (2005)). 
Fig. 19 shows the factors, impacting the early-stage venture capital in South Africa in Jones, Mlambo (2009), and Fig. 20 represents some information on the activity areas, where the venture capitalist is responsible for implementation in Luukkonen (2008).

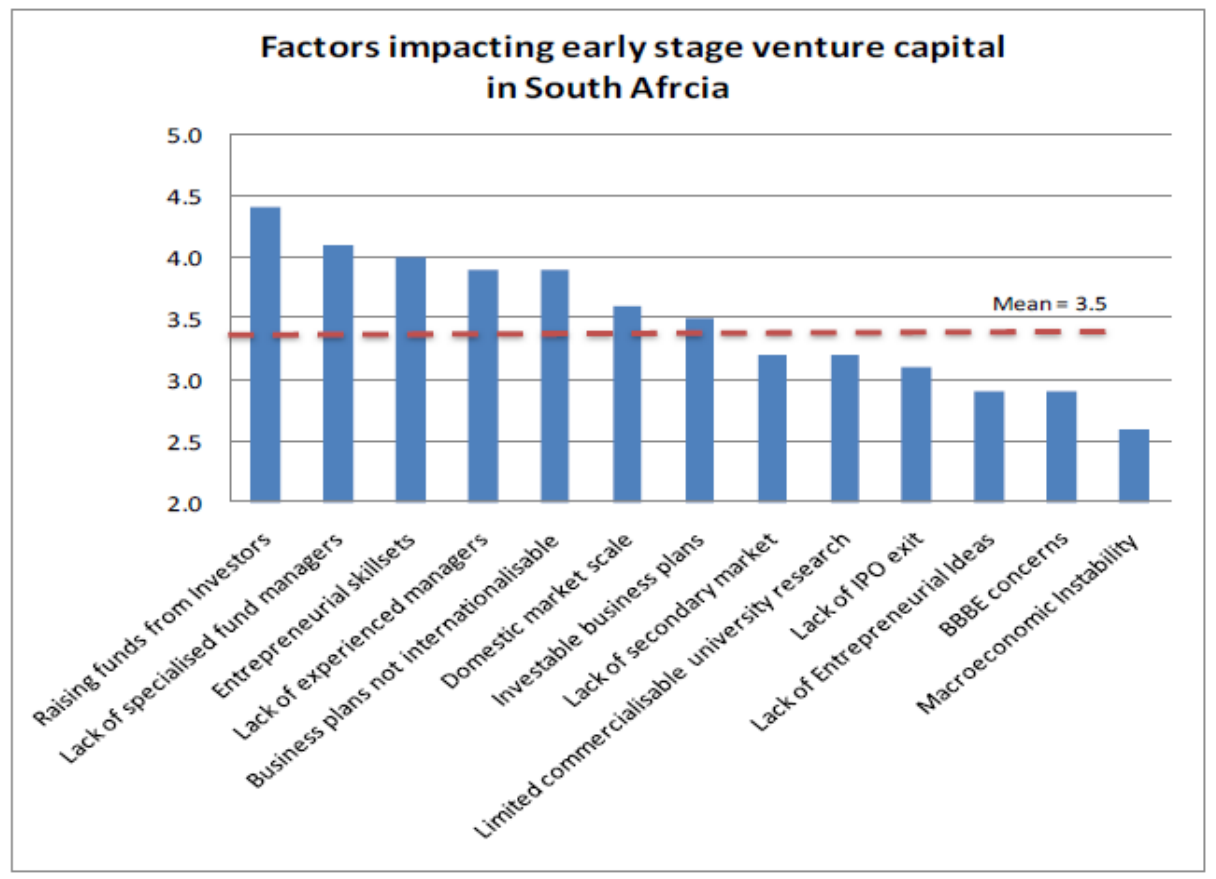

Fig. 19. Factors impacting early-stage venture capital in South Africa in Jones, Mlambo (2009).

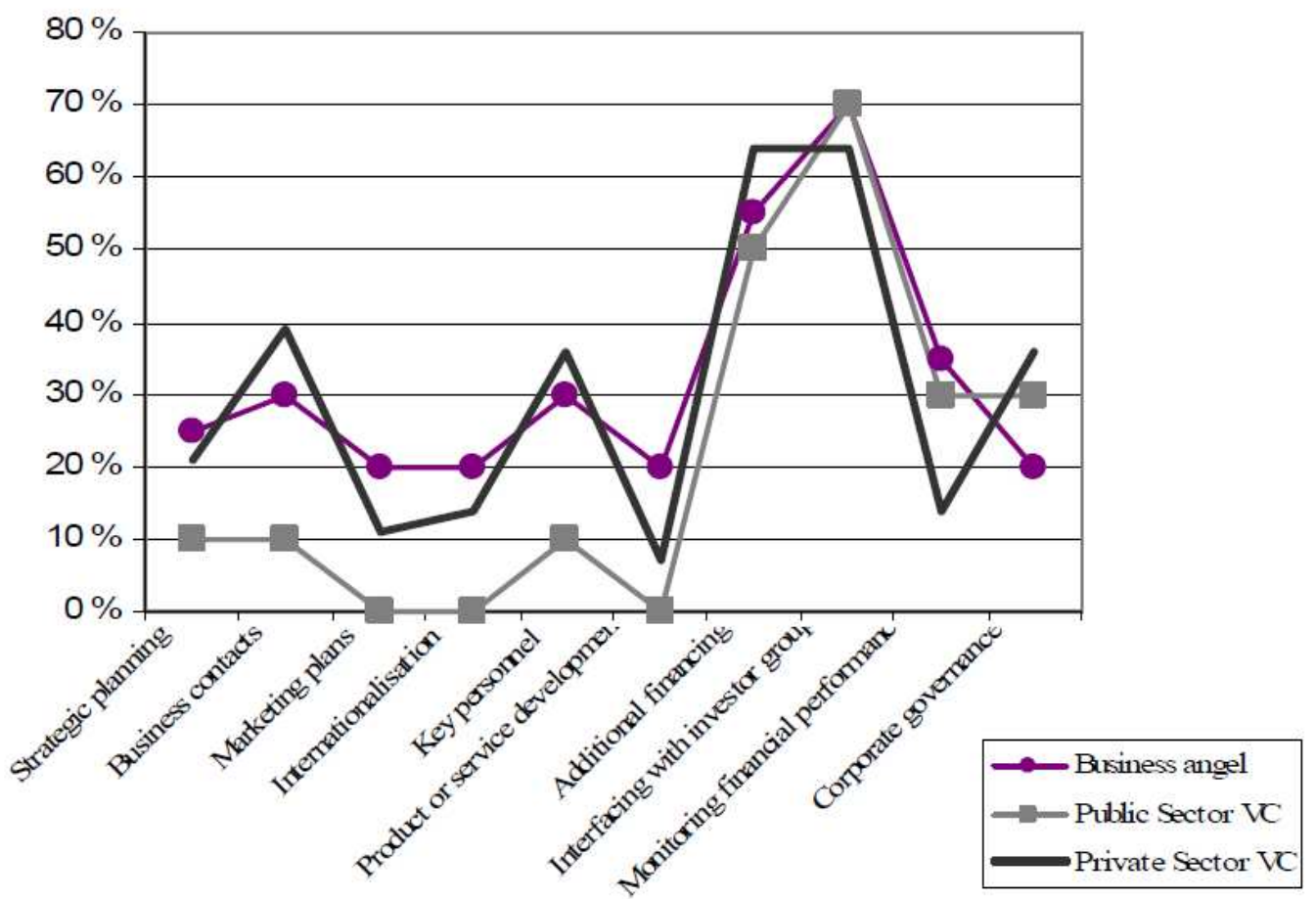

Fig. 20. Activity areas where the venture capitalist is responsible for implementation (after Luukkonen (2008)). 
Da Rin, Hege, Llobet, Walz (2005) write: "The theoretical and empirical literature has focused on a relative small number of factors as the leading performance drivers in venture capital success. First, venture capitalists are typically active investors: they provide monitoring and advising besides capital. Second, the venture capital industry has long resorted to a wide array of specific contractual mechanisms to mitigate agency conflicts, in particular instruments of contingent control and stage financing."

Aiming to increase the venture capital success, the venture capitalists tend to conduct the $V C$ networking and form the syndicates.

Da Rin, Hellmann, Puri (2011) explain: "Bubna et al. (2011) examine the clustering in $V C$ partner choices. They find that $V C s$ tend to syndicate with preferred partners drawn from clusters that they call $V C$ "communities." Using flexible community detection algorithms originating in the physical sciences, they examine the number of communities, their composition, and their effect on performance. They find that $V C s$ communities are structurally complex, with heterogeneity in some characteristics such as size and influence but homogeneity in characteristics in other dimensions such as stage focus. Firms funded by community VCs are more likely to experience a successful exit."

Lai (2005) writes: "Venture capital firms (VCs) form syndicates that compete to invest in deals." Fig. 21 shows the VCs networking scheme in Lai (2005).

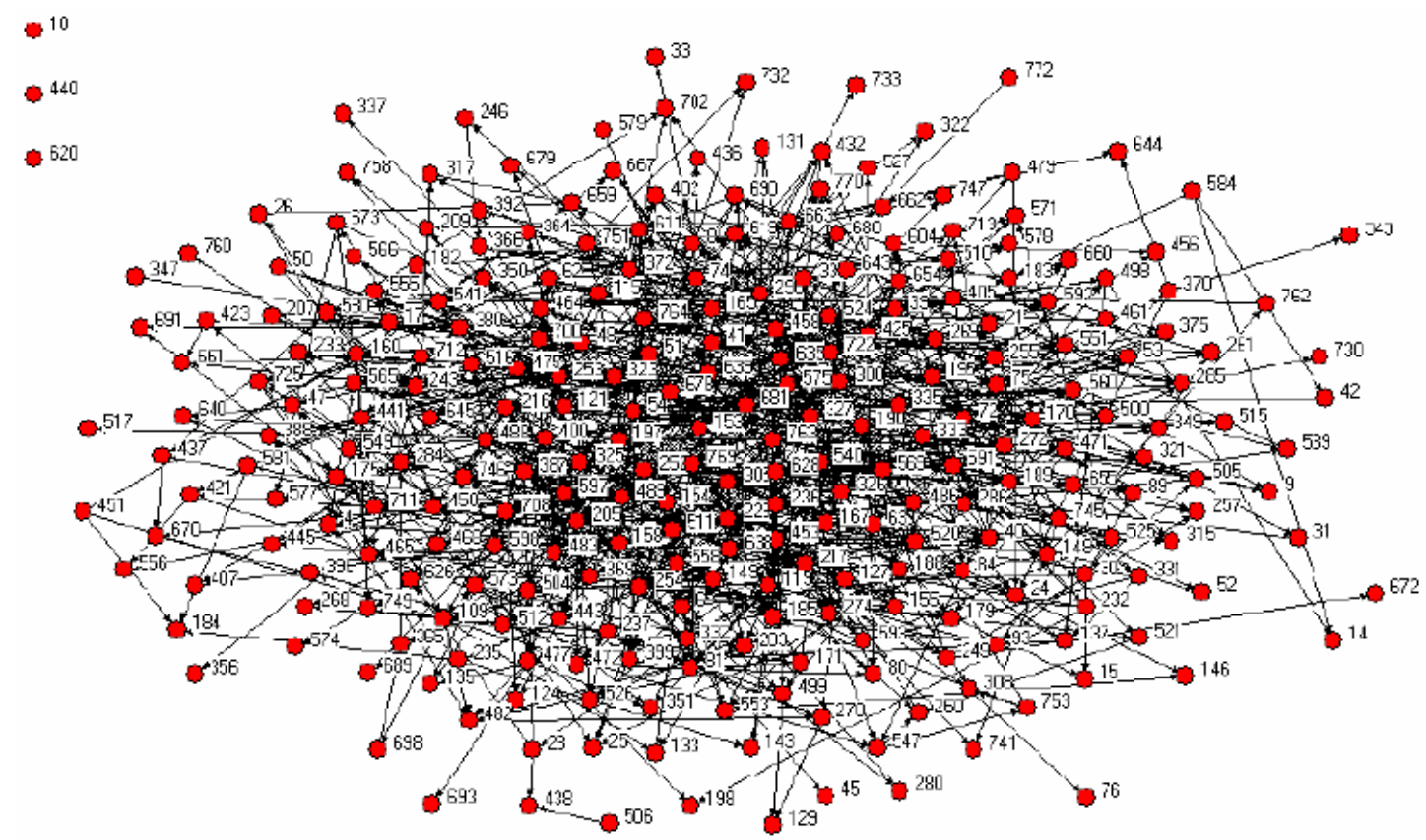

Fig. 21. VCs networking scheme: VCs are depicted as nodes. An arrow from one VC to another means that the former has selected the latter in a previous syndicate. Isolated nodes on left are VCs who select no VCs before. All lead VCs are shown, but only candidate VCs who have been selected by some lead VC are shown (after Lai (2005)). 
Let us discuss the asymmetric information problem between the various market agents. The impact by the investments on the economy performance has been studied in Akerlof, Stiglitz (1966). The theory of innovation has been researched in Stiglitz (1969). The fact that the competition and entrepreneurship are important factors for the economy growth has been outlined in Kirzner (1973). The theory of firm has been well formulated in Jensen, Meckling (1976), Lucas (1978). The problems of the imperfect information, uncertainty and credit rationing between the market agents in the conditions of market economy have been considered in Jaffee, Russell (1976). The existence of the credit rationing problem in the markets with the incomplete information has been also confirmed in Stiglitz, Weiss (1981), Stiglitz (1988). The new theory of the firm, taking to the account the asymmetric information flows, has been proposed in Greenwald, Stiglitz (1990). It has been discovered that in Greenwald, Stiglitz (1990): "Imperfect information affects both the internal organization of firms and its external relations with labor, capital and product markets." The asymmetric effect of diffusion processes has been explained in Richiardi, Gallegati, Greenwald, Stiglitz (2007).

Zhang (2007b) explains: "VC investment is characterized by an asymmetric information problem between equity investors and the entrepreneur Leland and Pyle (1977); Amit et al. (1990); Fried and Hisrich (1994); Gompers (1995). VC investors often bet millions of dollars on a start-up, whose future success will in large part be determined by the quality of the founder. Usually investors possess less information about the entrepreneur's ability and the viability of his business plan than the entrepreneur himself does. This information asymmetry prevents venture capitalists from investing a large amount of money in start-ups." Zhang (2007b) notes: "There are many ways to overcome this asymmetric information problem Gompers and Lerner (1999). In a sense, the general practice of staged investment in the $V C$ industry is meant to provide a partial solution to this problem Gompers (1995). Venture capitalists almost always make investment decisions stage by stage: they only provide a small amount of money to a start-up initially, and base later investment decisions on the start-up's performance. In this way, venture capitalists can evaluate the entrepreneur's ability and the viability of his plan over time. Furthermore, as another solution to the asymmetric information problem, venture capitalists rely heavily on the referrals of social contacts to identify and evaluate an entrepreneur Tyebjee and Bruno (1984)."

Pennacchio (2013) writes: "A measure that is widely used in the economic literature to examine the role of venture capitalists in IPOs is the underpricing: the difference between the price of the shares in the first day of trading and the price of the shares offered to investors. The analysis of the venture capital backing's effect on the IPO underpricing is a suitable way to 
investigate whether venture capitalists are able to reduce the asymmetric information that arises in the IPO process and the cost of flotation for the issuers. Many theories explain the underpricing in a context of asymmetric information between the actors involved in the IPO, typically issuing firms, underwriters and investors Baron (1982); Rock (1986); Benveniste and Spindt (1989); Beatty and Ritter (1986). According to such theories, the underpricing represents a proxy of the ex-ante uncertainty regarding the issue that increases with the increasing of the degree of information asymmetries Eckbo (2008)."

We propose that the information signals can be mixed and self-modulated during the asymmetric information flows in the information transmission channels between the various market agents, resulting in an origination of the different types of the nonlinearities such as the high order harmonics, which may have a considerable impact on the VC's decision making process on the venture capital investments in the diffusion-type financial system. In our opinion, these nonlinearities have to be taken to an account during the venture capital optimal investment portfolio strategies selection process, which is all about making the right investment choices, using the econophysical econometrical analysis in Greene (2008) with the application of the inductive, deductive and abductive logics in Martin (1998-1999, 2005-2006). Thus, let us provide the definitions for the different types of logics, which can be used in the venture capital optimal investment portfolio strategies selection process in Martin (1998-1999, 2005-2006):

Inductive logic - the logic of what is operative - reasons from the specific to the general. Induction allows inferring $\boldsymbol{a}$ entails $\boldsymbol{b}$ from multiple instantiations of $\boldsymbol{a}$ and $\boldsymbol{b}$ at the same time.

Deductive logic — the logic of what must be - reasons from the general to the specific. Deduction allows deriving $\boldsymbol{b}$ as a consequence of $\boldsymbol{a}$. In other words, deduction is the process of deriving the consequences of what is assumed.

Abductive logic -the logic of what could possibly be true -reasons through successive approximation. Abduction allows inferring $\boldsymbol{a}$ as an explanation of $\boldsymbol{b}$, because of this, abduction allows the precondition $\boldsymbol{a}$ to be inferred from the consequence $\boldsymbol{b}$.

\section{Conclusion}

This research article presents some innovative research results on the venture capital optimal investment portfolio strategies selection in the diffusion-type financial systems in the imperfect highly volatile global capital markets with the incomplete information, which are characterized by the asymmetric information flows and impacted by the various types of the 
nonlinearities. We discussed the venture capital firms with the different organizational structures: the corporation funded venture capital firm, investment bank funded venture capital firm, private equity funded venture capital firm, state funded venture capital firm. We provided a comprehensive review on the venture capital investments academic literature. We considered the complicated issues on the venture capital optimal investment portfolio strategies selection, evaluation of the possible returns on the investments, and implementation of the exit strategies for the venture capital investment schemes. We proposed that the information signals can be mixed and self-modulated during the asymmetric information flows in the information transmission channels between the various market agents, resulting in an origination of the various types of the nonlinearities, which may have a considerable impact on the venture capital investments in the diffusion-type financial system. These nonlinearities have to be taken to an account during the venture capital optimal investment portfolio strategies selection process, which is all about making the right investment choices during the econophysical econometrical analysis with the application of the inductive, deductive and abductive logics. In our opinion, the development of venture capital industry, including the venture capital firms and the venture capital funded high-tech startups, can greatly improve the macroeconomic indicators of national economies by creating the new hi-tech startups, generating the new wealth, and increasing the Gross Domestic Product. We focus on the fact that the business reputation of a venture capital firm is a valuable firm's asset in the conditions of strong business competition. Of course, there are some differences between the $V C$ financing approaches in various countries, for instance, Motohashi (2010) writes: "Japanese VCs are less likely to invest in early stage startups, while US ones are involved in "screening" and "monitoring" activities of venture businesses. This may be related to under-developed private equity markets in Japan and substantial VC investments in Japan are organized by bank affiliated VCs." We think that, in the present time, the VC industry in the State of Queensland is in a rapid development phase, because the State of Queensland has adopted all the necessary policies to become a very attractive place for the venture capital investments in the hi-tech startups in Australia, comparing to other regions in the World. We think that the globalization will have a considerable influence on the $V C$ industry, creating the new high potential growth financial and hi-tech clusters with a big number of the VC firms in Australia and in Asia. At the same time, we have to remember that as it is explained in Lerner (2012): "My analysis suggests that the market for venture capital may be subject to substantial imperfections and that these imperfections may substantially lower the total social gain achieved by venture finance." We would like to conclude with the optimistic statement in Kraeussl, 
Krause (2011): "Entrepreneurship, innovation, and venture capital (VC) are pivotal to success in economic development, as they provide for wealth creation and a rising standard of living."

\section{Acknowledgement}

The initial idea to make an innovative research on the venture capital optimal investment portfolio strategies selection in the diffusion-type financial systems in the imperfect highly volatile global capital markets with the incomplete information, which are characterized by the asymmetric information flows and impacted by the various types of the nonlinearities, came up to the first co-author's mind during both:

1) the innovative research on the nonlinearities in the microwave superconductivity at James Cook University in Townsville, Queensland, Australia, and

2) the $R \& D$ practices in the venture capital funded hi-tech startups in Brisbane, Queensland in Australia in recent years.

In this research, we proposed that the information signals can be mixed and selfmodulated during the asymmetric information flows in the information transmission channels between the market agents, resulting in the origination of the various types of the nonlinearities such as the high order harmonics, which may have a considerable impact on the venture capital investments in the diffusion-type financial system. In our opinion, these nonlinearities have to be taken to an account during the venture capital optimal investment portfolio strategies selection process, which is all about making the right investment choices during the econophysical econometrical analysis process with the application of the inductive, deductive and abductive logics. We firmly believe that the venture capitalists must think wisely on the venture capital optimal investment portfolio strategies selection in the diffusion-type financial systems in the imperfect highly volatile global capital markets with the incomplete information, which are characterized by the asymmetric information flows and impacted by the various types of nonlinearities. In our opinion, there are the numerous growing risk factors, which have to be considered by the venture capitalists during the venture capital investment decision making process in the diffusion type financial systems.

We would like to say that, in our research, the main direction of thinking on the venture capital optimal investment portfolio strategies selection in the diffusion-type financial systems in the imperfect highly volatile global capital markets with the incomplete information, which are characterized by the asymmetric information flows and impacted by the various types of nonlinearities, is mainly defined by some very innovative initial research results on the imperfect 
information, asymmetric information, and theory of firm, which were obtained by Prof. Joseph E. Stiglitz, Columbia University, and The Sveriges Riksbank Prize in Economic Sciences in Memory of Alfred Nobel 2001 laureate, who was graduated with the Ph. D degree from Massachusetts Institute of Technology (MIT) in Stiglitz (2001, 2002): "It was the hey-day of MIT with first-rate professors (I had at least four Nobel Prize winners as professor: Samuelson (Nobel Laureate in 1970), Solow (Nobel Laureate in 1987), Modigliani (Nobel Laureate in 1985), and Arrow (Nobel Laureate in 1972)) teaching first-rate students." Analyzing the recent developments in the US economy, Prof. Joseph E. Stiglitz, Columbia University provided the following accurate characteristics to the present state of the US financial system in Stiglitz (2013): "The financial system has become even more concentrated, exacerbating the problem of banks that are not only too big, too interconnected, and too correlated to fail, but that are also too big to manage and be held accountable." In our opinion, Prof. Joseph E. Stiglitz was one of the first scientists, who mentioned a great possible influence by the asymmetric information flows between the various market agents on the venture capital investments in the diffusion-type financial system. We think that these risk factors can be directly connected with 1) the financial and monetary stabilities of financial systems; 2) the increasing degree of volatility in the global capital markets in the time of uncertainty; 3) the presence of necessary knowledge base and practical skills to precisely evaluate the new innovative technology, necessary venture capital investments and possible returns-on-investments.

We would like to express our kind sincere gratitude to Prof. Dr. Ben Shalom Bernanke, Chairman of the Board of Governors of the Federal Reserve System for the insightful thoughtful scientific discussions in the finances and economics and considerable research interest by encouraging us to think wisely in the course of our advanced research and to make everything possible to complete the research program timely by giving us access to the electronic copies of his most recent research articles, analytic research reports, informative slide presentations, minutes of research discussions on the various financial topics and strategic economic issues within the scope of our research interest as well as an electronic copy of his very innovative Ph. D. Thesis: "Long-term commitments, dynamic optimization, and the business cycle," supervised by Stanley Fischer, Professor of Economics, Massachusetts Institute of Technology, USA. Bernanke (2013b) stated recently: "When I was in graduate school, my teacher, Stanley Fischer, introduced me to the work of Milton Friedman and Anna Schwartz, which demonstrated that monetary policy can have enormous effects on how the economy performs, for good or for ill. That realization helped motivate me to specialize, in graduate school and after, in monetary economics and related fields." Bernanke (2013c) continued to explain: "Stan was my teacher in 
graduate school, and he has been both a role model and a frequent adviser ever since. An expert on financial crises, Stan has written prolifically on the subject and has also served on the front lines, so to speak--notably, in his role as the first deputy managing director of the International Monetary Fund during the emerging market crises of the 1990s. Stan also helped to fight hyperinflation in Israel in the 1980s and, as the governor of that nation's central bank, deftly managed monetary policy to mitigate the effects of the recent crisis on the Israeli economy. Subsequently, as Israeli housing prices ran upward, Stan became an advocate and early adopter of macroprudential policies to preserve financial stability. Stan frequently counseled his students to take a historical perspective, which is good advice in general, but particularly helpful for understanding financial crises, which have been around a very long time." Describing the current economic crisis Bernanke (2013c) makes the following comments: "The recent crisis echoed many aspects of the 1907 panic. Like most crises, the recent episode had an identifiable trigger-in this case, the growing realization by market participants that subprime mortgages and certain other credits were seriously deficient in their underwriting and disclosures. As the economy slowed and housing prices declined, diverse financial institutions, including many of the largest and most internationally active firms, suffered credit losses that were clearly large but also hard for outsiders to assess. Pervasive uncertainty about the size and incidence of losses in turn led to sharp withdrawals of short-term funding from a wide range of institutions; these funding pressures precipitated fire sales, which contributed to sharp declines in asset prices and further losses."

Let us note that the financial crisis in the USA has a strong impact on the venture capital investments in the conditions of the diffusion-type financial system in Block, Sandner (2009): "a financial crisis can have a strong, exogenous impact on $V C$ activity, which can then lead to a severe "funding gap" in the financing of technological development and innovation. Unlike the last slowdown of $V C$ activities after the collapse of the New Economy bubble in the year 2000, the current slowdown came more as an exogenous shock. In the current crisis, it was clearly not unrealistic expectations regarding the Internet and the New Economy but instead a malfunctioning financial sector that initiated the downturn that caused the slowdown." Let us also highlight the fact that, in the conditions of the economic crisis, many serious questions have to be answered in Block, Sandner (2009): "Many questions are left unanswered and provide good opportunities for future research.

1. Does the impact of financial crises on $V C$ activity differ among industries or regions? For example, is there a similar effect of the financial crisis in biotechnology or semiconductor fields? 
2. How do start-ups receiving funding in this financial crisis differ from start-ups that had received funding before the financial crisis?

3. Is there a kind of selection effect, where only the more promising ventures receive funding?

4. How do the start-ups respond to the challenges posed by the financial crisis and the difficulties encountered in the search for $V C$ funding?

5. Does a lower success rate of $V C$-backed companies lead to a decline in the performance of $V C$ funds? And ultimately, over a long time period, does $V C$ as a financing instrument for innovative start-ups become severely harmed as an effect of the crisis?"

Most importantly, we would like to highlight the fact that there are not enough words to express the first author's sincere thanks to Prof. Janina E. Mazierska, Personal Chair, Electrical and Computer Engineering Department, James Cook University, Townsville, Australia and former IEEE Director and IEEE Fellow, who helped the first author to develop both the logical mathematical analysis skills and the abstract scientific thinking ability to tackle the complex scientific problems on the nonlinearities in the microwave superconductivity as well as on the nonlinearities in the finances, applying the interdisciplinary scientific knowledge together with the advanced computer modeling skills during his innovative research projects at James Cook University in Townsville, Australia in 2000-2013 after the graduation from V. N. Karazyn Kharkov National University in Kharkov, Ukraine in 1994 - 1999.

We also thank Prof. Oleg P. Ledenyov for a number of interesting encouraging thoughtful scientific discussions and his helpful research comments on the special criteria for the virtuous optimal venture capital investment strategies selection in the process of the venture capital optimal investment portfolio allocation in the diffusion-type financial systems in the imperfect highly volatile global capital markets with the incomplete information, which are usually characterized by the asymmetric information flows and affected by the various types of nonlinearities.

Dr. Jack Welch, former Chairman and CEO of General Electric (GE) corporation once stated in Welch (2005): "My obsession with golf lasted for almost sixty years, from my first days playing and caddying at age ten. ... Golf was wonderful. It gave me great friends that I've enjoyed for decades and always will, and all the fun of competing." The matter of fact is that, at present time, the most successful venture capitalists have a lifelong passion for the innovation, intensively relying on the mobile offices with the Apple's MacBookPro laptop computers, iPAD Air tablets and iPhone5S mobile phones to connect, discuss, analyze and make the most profitable venture capital investment deals, when playing the golf in Europe, North America, 
Asia and Australia in the various time zones. At the same time, the authors as well as some other venture capitalists keep an old tradition to determine the time for business meetings and to make the business decisions in various time zones, using the high complication Swiss mechanical watches by Vacheron Constantin. Finally, it worth to say that, playing the golf around the World, we frequently apply the integrative creative thinking techniques to select the VC virtuous investment strategies and make the VC investment deals, hence we deeply grateful to Profs. Roger L. Martin and John C. Hull from the Rotman School of Management, University of Toronto, Canada for the numerous thoughtful long-hours scientific discussions on the nonlinearities in the finances.

*E-mail: dimitri.ledenyov@my.jcu.edu.au

\section{References:}

1. Rind K W 1981 The role of venture capital in corporate development Strategic Management Journal 2 pp 169 - 180.

2. Tyebjee T T, Bruno A V 1981 Venture capital decision making: Preliminary results from three empirical studies Frontiers of Entrepreneurship Research pp 316 - 334.

3. Bruno A V, Tyebjee $\mathrm{T} \mathrm{T} 1983$ The one that got away: A study of ventures rejected by venture capitalists in Hornaday J A, Timmons J A, Vesper K H (editors) Frontiers of entrepreneurship research Babson College Wellesley MA pp 289 - 306.

4. Tyebjee T, Bruno A 1984 A model of venture capitalist investment activity Management Science 30 pp 1051 - 1066.

5. Bruno A V, Tyebjee $\mathrm{T} T 1986$ The destinies of rejected venture capital deals MIT Sloan Management Review 27 pp 43 - 53.

6. Chan Y S 1983 On the positive role of financial intermediation in allocation of venture capital in a market with imperfect information Journal of Finance 38 pp 1543 - 1568.

7. Felda H G, DeNino M J, Salter M S 1983 When corporate venture capital doesn't work Harvard Business Review 61 May - June pp 114 - 120.

8. Wilson J W 1983 The new ventures - inside the high stakes world of venture capital Addison Wesley Publishing Company Boston MA USA.

9. Merkle E 1984 Venture capital als instrument des technologiemanagements Betriebs-Berater 39 pp 1060 - 1064.

10. Hutt R W, Thomas B 1985 Venture capital in Arizona Frontiers of Entrepreneurship Research pp 155 - 169. 
11. MacMillan I, Siegel R, Narasimha P 1985 Criteria used by venture capitalists to evaluate new venture proposals Journal of Business Venturing 1 pp 119 - 128.

12. MacMillan I C, Zemann L, Narasimha P N 1987 Criteria distinguishing successful from unsuccessful ventures in the venture screening process Journal of Business Venturing 2 (2) pp 123 - 137.

13. Beatty R P, Ritter J 1986 Investment banking, reputation, and the underpricing of initial public offerings Journal of Financial Economics 15 pp 213 - 232.

14. Nevermann H, Falk D 1986 Venture capital - Ein betriebswirtschaftlicher und steuerlicher vergleich zwischen den USA und der Bundesrepublik Deutschland NOMOS Verlagsgesellschaft Baden-Baden Germany.

15. Timmons J A, Bygrave W D 1986 Venture capital's role in financing innovation for economic growth Journal of Business Venturing 1 pp 161 - 176.

16. Block Z, Ornati O A 1987 Compensating corporate venture managers Journal of Business Venturing 2 pp 41 - 52.

17. Bygrave W D 1987 Syndicated investments by venture capital firms: A networking perspective Journal of Business Venturing 2 (2) pp 139 - 154.

18. Bygrave W D, Timmons J A 1992 Venture capital at the crossroads Harvard Business School Press Boston MA pp 1 - 79.

19. Robinson R B 1987 Emerging strategies in venture capital industry Journal of Business Venturing vol 2 pp 53 - 77.

20. Ruhnka J C, Young J E 1987 A venture capital model of the development process for new ventures Journal of Business Venturing vol 2 pp 167 - 184.

21. Ruhnka J C, Young J E 1991 Some hypotheses about risk in venture capital investing Journal of Business Venturing vol 6 pp 115 - 133.

22. Ruhnka J C, Felman H D, Dean T J, 1992 The "living dead" phenomenon in venture capital investments Journal of Business Venturing vol 7 issue 2 pp 137 - 155.

23. Sandberg W R, Hofer C W 1987 Improving new venture performance: The role of strategy, industry structure, and the entrepreneur Journal of Business Venturing 2 (1) pp 5 - 28.

24. Stedler H 1987 Venture capital und geregelter freiverkehr: Eine empirische studie Frankfurt am Main Germany.

25. Brophy D J, Guthner M W 1988 Publicly traded venture capital funds: Implications for institutional 'Fund of Funds' investors Journal of Business Venturing 3 (3) pp 187 - 206.

26. Clark R 1988 Venture capital in Britain, America, and Japan Croom Helm London UK. 
27. Eisinger P 1988 The rise of the entrepreneurial state: State and local economic development policy in the United States University of Wisconsin Press Madison USA.

28. Eisinger P 1993 State venture capitalism, state politics, and world of high risk investment Economic Development Quarterly 7 (2) pp 131 - 140.

29. Florida R L, Kenney M 1988 Venture capital-financed innovation and technological change in the USA Research Policy 17 (3) pp 119 - 137.

30. Florida R, Smith D F 1993 Keep the government out of Venture Capital Issues in Science and Technology 9 pp $61-68$.

31. Gladstone D 1988 Venture capital handbook. New and revised. An entrepreneur's guide to obtaining capital to start a business, buy a business, or existing business Prentice Hall USA pp 1 - 350.

32. Harris M, Raviv A 1988 Corporate governance: Voting rights and majority rules Journal of Financial Economics 20 pp 203 - 235.

33. Sandberg W R, Schweiger D M, Hofer Ch W 1988 Use of verbal protocols in determining venture capitalists' decision process Entrepreneurship Theory and Practice 13 pp 182 - 196.

34. Schmidt R H 1988 Venture capital in Deutschland: Ein problem der qualität Die Bank 4 pp $184-187$.

35. Siegel R, Siegel E, and MacMillan I 1988 Corporate venture capitalists: Autonomy, obstacles and performance Journal of Business Venturing 3 pp 233 - 247.

36. Tirole J 1988 The theory of industrial organization Cambridge MIT Press Cambridge Massachusetts USA.

37. Benveniste L M, Spindt P A 1989 How investment bankers determine the offer price and allocation of new issues Journal of Financial Economics 24 pp 343 - 361.

38. Gorman M, Sahlman W 1989 What do venture capitalists do? Journal of Business Venturing 4 pp 231 - 248.

39. Holmstrom B, Tirole J 1989 The theory of the firm in Schmalensee R, Willig R (editors) Handbook of industrial economics Chapter 2 Part 1 Elsevier Publishing BV Amsterdam The Netherlands.

40. Poterba J 1989a Venture capital and capital gains taxation Tax Policy and the Economy 3 p 47.

41. Poterba J 1989b Capital gains tax policy toward entrepreneurship National Tax Journal 42 pp 375 - 390.

42. Amit R, Glosten L, Muller E 1990a Entrepreneurial ability, venture investments, and risk sharing Management Science 36 pp 1232 - 1245. 
43. Amit R, Glosten L, Muller E 1990b Does venture capital foster the most promising entrepreneurial firms? California Management Review pp 102 - 111.

44. Amit R, Brander J, Zott C 1998 Why do venture capital firms exist? Theory and Canadian evidence Journal of Business Venturing 13 pp 441 - 466.

45. Barry C, Muscarella C, Peavy J, Vetsuypens M 1990 The role of venture capital in the creation of public companies: evidence from the going public process Journal of Financial Economics 27 pp 447 - 471.

46. Barry C 1994 New directions in research on venture capital finance Financial Management 23 (3) pp 3 - 15.

47. Chan Y-S, Siegel D, Thakor A 1990 Learning, corporate control and performance requirements in venture capital contracts International Economic Review 31 pp 365 - 381.

48. Hisrich R D, Jankowitz A D 1990 Intuition in venture capital decisions: An exploratory study using a new technique Journal of Business Venturing 5 pp 49 - 62.

49. Sahlman W 1990 The structure and governance of venture-capital organizations Journal of Financial Economics 27 pp 473 - 521.

50. Sykes H B 1990 Corporate venture capital: Strategies for success Journal of Business Venturing 5 pp 37 - 47.

51. Dixon R 1991 Venture capitalists and the appraisal of investments OMEGA The International Journal of Management Science 19 (5) pp 333 - 344.

52. Megginson W, Weiss K 1991 Venture capitalist certification in initial public offerings Journal of Finance 46 pp 879 - 903.

53. Megginson W 2004 Towards a global model of venture capital? Journal of Applied Corporate Finance 16 (1) pp 8 - 26.

54. Sapienza H 1992 When do venture capitalists add value? Journal of Business Venturing 7 pp 9 - 27.

55. Sapienza H, Gupta A 1994 Impact of agency risks and task uncertainty on venture capitalistCEO interaction Academy of Management Journal 37 pp 1618 - 1632.

56. Hall J, Hofer C 1993 Venture capitalists' decision criteria in new venture evaluation Journal of Business Venturing 8 pp 25 - 42.

57. Rosenstein J A, Bruno V, Bygrave W D, Taylor N T 1993 The CEO, venture capitalists, and the board Journal of Business Venturing 8 (2) pp 99 - 113.

58. Sahlman W A 1993 Aspects of financial contracting in venture capital in Chew D H (editor) The new corporate finance. Where theory meets practice McGraw-Hill pp 229 - 242. 
59. Admati A, Pfleiderer P 1994 Robust financial contracting and the role of venture capitalists Journal of Finance 49 pp 371 - 402.

60. Aghion P, Tirole J 1994 The management of innovation Quarterly Journal of Economics pp $1091185-1209$.

61. Anton J, Yao D 1994 Expropriation and inventions American Economic Review 84 pp 190 - 209.

62. Berglöf E 1994 A control theory of venture capital finance Journal of Law, Economics and Organization 10 pp $247-267$.

63. Bhidé A 1994 The origin and evolution of new businesses Oxford University Press Oxford UK.

64. Fried V, Hisrich R 1994 Toward a model of venture capital investment decision making Financial Management 23 (3) pp 28 - 37.

65. Gompers P 1994 The rise and fall of venture capital Business and Economic History 23 pp $1-26$.

66. Gompers P 1995 Optimal investment, monitoring, and the staging of venture capital Journal of Finance $\mathbf{5 0}$ pp 1461 - 1489.

67. Gompers P 1996 Grandstanding in the venture capital industry Journal of Financial Economics 42 pp 133 - 156.

68. Gompers P A 1998 Venture capital growing pains: Should the market diet? Journal of Banking and Finance 22 (6-8) pp 1089 - 1104.

69. Gompers P A 2002 Gompers P A 2002 Corporations and the financing of innovation: The corporate venturing experience Federal Reserve Bank of Atlanta Economic Review Fourth Quarter pp 1 - 18.

70. Gompers P, Lerner J 1996 The use of covenants: An empirical analysis of venture partnership agreements Journal of Law and Economics 39 pp 463 - 498.

71. Gompers P, Lerner J 1997 Risk and reward in private equity investments: The challenge of performance assessment Journal of Private Equity 1 pp 5 - 12.

72. Gompers P, Lerner J 1998a Venture capital distributions: Short-run and long-run reactions Journal of Finance $\mathbf{5 3}$ pp 2161 - 2183.

73. Gompers P, Lerner J 1998b What drives venture capital fundraising? Brookings Papers on Economic Activity Microeconomics pp 149 - 192.

74. Gompers P, Lerner J 1998c The determinants of corporate venture capital success: organizational structure, incentives, and complementarities National Bureau of Economic 
Research Conference volume on Concentrated Ownership NBER Cambridge Massachusetts USA.

75. Gompers P, Lerner J 1999a Conflict of interest in the issuance of public securities: Evidence from venture capital Journal of Law and Economics 42 pp 1 - 28.

76. Gompers P, Lerner J 1999b An analysis of compensation in the U.S. venture capital partnership Journal of Financial Economics 51 pp 3 - 44.

77. Gompers P, Lerner J 1999c Capital market imperfections in venture markets: A report to the advanced technology program US Department of Commerce US Government Washington USA.

78. Gompers P, Lerner J 1999d The venture capital cycle MIT Press Cambridge Massachusetts USA.

79. Gompers P, Lerner J 2000a The determinants of corporate venture capital success in Morck R (editor) Concentrated corporate ownership University of Chicago Press Chicago USA

80. Gompers P, Lerner J 2000b Money chasing deals? The impact of fund inflows on private equity valuation Journal of Financial Economics 55 pp 281 - 325.

81. Gompers P, Lerner J 2001a The venture capital revolution Journal of Economic Perspectives 15 pp $145-168$.

82. Gompers P, Lerner J 2001b The money of invention Harvard Business School Press Boston USA.

83. Baker M, Gompers P 2003 The determinants of board structure at the initial public offering Journal of Law and Economics 46 pp 569 - 598.

84. Gompers P, Lerner J, Scharfstein D 2005 Entrepreneurial spawning: Public corporations and the genesis of new ventures, 1986 to 1999 Journal of Finance $\mathbf{6 0}$ pp 577 - 614.

85. Gompers P A, Kovner A, Lerner J, Scharfstein D 2006 Skill vs luck in entrepreneurship and venture capital: Evidence from serial entrepreneurs NBER Working Paper no 12592.

86. Gompers P 2007 Venture capital in Eckbo E (editor) Handbook of corporate finance vol 1 North- Holland Amsterdam The Netherlands.

87. Gompers P, Kovner A, Lerner J, Scharfstein D 2008 Venture capital investment cycles: The impact of public markets Journal of Financial Economics 87 pp 1 - 23.

88. Gompers P, Kovner A, Lerner J 2009 Specialization and success: evidence from venture capital Journal of Economics and Management Strategy 18 pp 817 - 844.

89. Gompers P, Lerner J, Scharfstein D, Kovner A 2010 Performance persistence in entrepreneurship Journal of Financial Economics 96 pp 18 - 32. 
90. Knight R 1994 Criteria used by venture capitalists: A cross cultural analysis International Small Business Journal vol 13 no 1 pp 26 - 37.

91. Kroszner R, Rajan R 1994 Is the Glass-Steagall act justified? A study of the US experience with universal banking before 1933 American Economic Review 84 pp 810 - 832.

92. Lerner J 1994a Venture capitalists and the decision to go public Journal of Financial Economics 35 pp 293 - 316.

93. Lerner J 1994b The syndication of venture capital investments Financial Management 23 pp $16-27$.

94. Lerner J 1995a Venture capitalists and the oversight of private firms Journal of Finance $\mathbf{5 0}$ pp $301-318$.

95. Lerner J 1995b Patenting in the shadow of competitors Journal of Law and Economics vol 38 pp 463 - 488.

96. Lerner J 1998 Angel financing and public policy: An overview Journal of Banking and Finance 22 pp 773 - 783.

97. Lerner J 1999 The government as venture capitalist: The long-run impact of the SBIR program Journal of Business 72 pp 285 - 318.

98. Lerner J 2002 Boom and bust in the venture capital industry and the impact on innovation Federal Reserve Bank of Atlanta Economic Review Fourth Quarter USA pp 1 - 15.

99. Kortum S, Lerner J 1998 Does venture capital spur innovation? NBER Working Paper no W6846.

100. Kortum S, Lerner J 2000 Assessing the contribution of venture capital to innovation RAND Journal of Economics 31 (4) pp 674 - 692.

101. Lerner J, Shane H, Tsai A 2003 Do equity financing cycles matter? Evidence from biotechnology alliances Journal of Financial Economics 67 pp 411 - 446.

102. Lerner J, Schoar A 2004 The illiquidity puzzle: theory and evidence from private equity Journal of Financial Economics 72 pp 3 - 40.

103. Lerner J, Schoar A 2005 Does legal enforcement affect financial transactions? The contractual channel in private equity Quarterly Journal of Economics 120 pp 223 - 246.

104. Lerner J, Moore D, Shepherd S 2005 A study of New Zealand's venture capital market and implications for public policy A report to the Ministry of Research, Science and Technology New Zealand http://papers.ssrn.com/sol3/papers.cfm?abstract_id=1459175 .

105. Lerner J, Schoar A, Wongsunwai W 2007 Smart institutions, foolish choices? The limited partner performance puzzle Journal of Finance 62 pp 731 - 764. 
106. Lerner J 2008, 2009 Boulevard of broken dreams: Why public efforts to boost entrepreneurship and venture capital have failed Princeton University Press Princeton USA.

107. Lerner J, Sorensen M, Strömberg P 2009 What drives private equity activity and success globally in Gurung A, Lerner J (editors) Globalization of alternative investments Working Papers vol 2 The global economic impact of private equity report 2009 World Economic Forum Geneva Switzerland pp 63 - 98.

108. Chen H, Gompers P, Kovner A, Lerner J 2009 Buy local? The geography of successful and unsuccessful venture capital expansion Working Paper 15102 National Bureau of Economic Research Cambridge MA USA http://www.nber.org/papers/w15102 .

109. Lerner J, Tåg J 2012 Institutions and venture capital Working Paper 2012 : 17 Swedish Entrepreneurship Forum pp 1 - 31.

110. Puri M 1994 The long-term default performance of bank underwritten security issues Journal of Banking and Finance 18 pp 397 - 418.

111. Puri M 1996 Commercial banks in investment banking: Conflict of interest or certification role? Journal of Financial Economics 40 pp 373 - 401.

112. Puri M, Robinson D 2011 Optimism and economic choice Journal of Financial Economics 86 pp 71 - 99.

113. Anton J, Yao D 1995 Start-ups, spin-offs, and internal projects Journal of Law, Economics and Organization 11 pp 362 - 378.

114. Elango B, Fried V H, Hisrich R D, Polonchek A 1995 How venture capital firms differ Journal of Business Venturing vol 10 no 2 pp 157 - 179.

115. Hart O 1995 Firms, contracts, and financial structure Oxford University Press UK.

116. Jain B, Kini O 1995 Venture capitalist participation and the post-issue operating performance of IPO firms Managerial and Decision Economics 5 pp 593 - 606.

117. Loughran T, Ritter J 1995 The new issues puzzle Journal of Finance $\mathbf{5 0}$ pp 23 - 51.

118. Willner R 1995 Valuing start-up venture growth options Real options in capital investment Trigeorgies L (editor) Praeger pp 221 - 239.

119. Sapienza H, Manigart S, Vermeir 1996 Venture capital governance and value-added in four countries Journal of Business Venturing 11 pp 439 - 469.

120. Manigart S, Wright M, Robbie K, Desbrieres P, De Waele K 1997 Venture capitalists appraisal of investment projects: An empirical European study Entrepreneurship Theory and Practice vol 21 pp 29 - 43.

121. Manigart S, De Waele K, Wright M, Robbie K, Desbrieres P, Sapienza H, Beekman A 2000 Venture capitalists, investment appraisal and accounting information: A comparative 
study of the USA, UK, France, Belgium and Holland European Financial Management 6 (3) pp 389 - 403.

122. Manigart S, De Waele K, Wright M, Robbie K, Desbrieres P, Sapienza H J, Beekman A 2002 The determinants of the required returns in venture capital investments: a five-country study Journal of Business Venturing 17 pp 291 - 312.

123. Manigart S, Baeyens K, Hyfte W V 2002 The survival of venture capital backed companies Venture Capital vol 4 no 2 pp 103 - 124.

124. Muzyka D, Birley S, Leleux B 1996 Trade-offs in the investment decisions of European VCs Journal of Business Venturing 11 pp 273 - 288.

125. Packer F 1996 Venture capital, bank shareholding, and IPO underpricing in Japan in Levis M (editor) Empirical issues in raising equity capital North-Holland Amsterdam The Netherlands.

126. Pettway R, Kaneko $\mathrm{T} 1996$ The effects of removing price limits and introducing auctions upon short-term IPO returns: The case of Japanese IPOs Pacific-Basin Finance Journal 4 pp $241-158$.

127. Amit A R, Brander J, Zott C 1997 Venture capital financing of entrepreneurship in Canada in Halpern $\mathrm{P}$ (editor) Financing innovative enterprise in Canada University of Calgary Press Calgary Alberta Canada pp 237 - 277.

128. Brav A, Gompers P 1997 Myth or reality? The long-run underperformance of initial public offerings: Evidence from venture- and non venture-capital-backed companies Journal of Finance $\mathbf{5 2}$ pp 1791 - 1821.

129. Cai J, Wei K C J 1997 The investment and operating performance of Japanese Initial Public Offerings Pacific - Basin Finance Journal 5 pp 389 - 417.

130. Chevalier J, Ellison G 1997 Risk taking by mutual funds as a response to incentives Journal of Political Economy 105 pp 1167 - 1200.

131. Gilford S 1997 Limited attention and the role of the venture capitalist Journal of Business Venturing vol 12 pp 459 - 482.

132. Karsai J, Wright M, Filatotchev I 1997 Venture capital in transition economies: The case of Hungary Entrepreneurship Theory and Practice 21 (4) pp 93 - 110.

133. Wright M, Robbie K, Ennew Ch 1997 Venture capitalists and serial entrepreneurs Journal of Business Venturing 12 pp 227 - 249.

134. Bergemann D, Hege U 1998 Venture capital financing, moral hazard, and learning Journal of Banking and Finance 22 pp 703 - 735. 
135. Berger A, Udell G 1998 The economics of small business finance: the roles of private equity and debt markets in the financial growth cycle Journal of Banking and Finance 22 pp 613 - 673.

136. Berger A, Schaek K 2011 Small and medium-sized enterprises, bank relationship strength, and the use of venture capital Journal of Money, Credit and Banking $\mathbf{4 3}$ pp $461-490$.

137. Black B, Gilson R 1998 Venture capital and the structure of capital markets: Banks versus stock markets Journal of Financial Economics 47 pp 243 - 277.

138. Cornelius B, Isaksson A 1998 Venture capital incentives: A two country comparison 10th Nordic Conference on Small Business Research Växjö University Växjö.

139. Fried V H, Bruton G D, Hisrich R D 1998 Strategy and the board of directors in venture capital - backed firms Journal of Business Venturing vol 13 pp 493 - 503.

140. Gerke W 1998 Market failure in venture capital markets for new medium and small enterprises in Hopt $\mathrm{K} \mathrm{J}$ et al (editors) Comparative corporate governance - The state of the art and emerging research Clarendon Press Oxford UK pp 607 - 635.

141. Hellmann $\mathrm{T} 1998$ The allocation of control rights in venture capital contracts RAND Journal of Economics 29 pp 57 - 76.

142. Hellmann Th F 2000 Venture capitalists: The coaches of Silicon Valley in Lee Ch-M, Miller W F Hancock M G, Rowen H S (editors) The Silicon Valley edge: A habitat for innovation and entrepreneurship Stanford University Press Stanford USA pp 276 - 294.

143. Hellmann T, Puri M 2000 The interaction between product market and financing strategy: The role of venture capital Review of Financial Studies 13 pp 959 - 984.

144. Hellmann T 2002 A theory of strategic venture investing Journal of Financial Economics 64 pp 285 - 314.

145. Hellmann T, Puri M 2002 Venture capital and the professionalization of start-up firms: Empirical evidence Journal of Finance 57 pp 169 - 197.

146. Hellmann Th, Lindsey L, Puri M 2004 Building relationships early: Banks in venture capital Working Paper 10535 National Bureau of Economic Research USA http://www.nber.org/papers/w10535 .

147. Hellmann T 2006 IPOs, acquisitions, and the use of convertible securities in venture capital Journal of Financial Economics 81 pp 649 - 679.

148. Hellmann T 2007 Entrepreneurs and the process of obtaining resources Journal of Economics and Management Strategy 16 pp 81 - 109. 
149. Hellmann T, Lindsey L, Puri M 2008 Building relationships early: Banks in venture capital Review of Financial Studies 21 pp 513 - 541.

150. Hyde A 1998 Silicon valley's high-velocity labor market Journal of Applied Corporate Finance 11 pp 28 - 37.

151. Jacobs O, Scheffler W 1998 Unternehmensbesteuerung und rechtsform, handbuch zur besteuerung deutscher unternehmen 2nd edition Beck München Germany.

152. Karsai J 1998 The appearance of venture capital in the Hungarian market and its participation in innovative processes HFEP Research Booklet no 9 Hungarian Foundation for Enterprise Promotion and its Network Budapest Hungary.

153. Karsai J, Wright M, Dudzinski Z, Morovic J 1999 Venture capital in transition economies: The cases of Hungary, Poland and Slovakia in Wright M, Robbie K (editors) Management buy-outs and venture capital Edward Elgar Cheltenham pp 81 - 114.

154. Karsai J 2003 What has the state got to do with the venture capital market? Public financing of venture capital in Hungary Acta Oeconomica vol 53 no 3 pp $271-291$.

155. Karsai J 2004 Can the state replace private capital investors? Public financing of venture capital in Hungary KTK/IE Discussion Papers 2004/9 Institute of Economics Hungarian Academy of Sciences Budapest Hungary HU ISSN 1785-377X ISBN 9639588091 pp 1 - 24.

156. Lin T, Smith R 1998 Insider reputation and selling decisions: The unwinding of venture capital investments during equity IPOs Journal of Corporate Finance 4 pp 241 - 263.

157. Marx L 1998 Efficient venture capital financing combining debt and equity Review of Economic Design 3 pp 371 - 387.

158. Marx L, Strumsky D, Fleming L 2009 Mobility, skills, and the Michigan non-compete experiment Management Science 55 pp 875 - 889.

159. Murray G C, Marriott R 1998 Why has the investment performance of technologyspecialist European venture capital funds been so poor? Research Policy 27 pp 947 - 976.

160. Prowse S 1998 Angel investors and the market for angel investments Journal of Banking and Finance 22 pp 785 - 792.

161. Rajan R, Zingales L 1998 Financial dependence and growth American Economic Review 88 pp 59 - 86.

162. Trester J 1998 Venture capital contracting under asymmetric information Journal of Banking and Finance 22 pp 675 - 699.

163. Wright M, Robbie K 1998 Venture capital and private equity: A review and synthesis Journal of Business Finance and Accounting 25 (5) pp 521 - 570. 
164. Zider B 1998 How venture capital works Harvard Business Review pp 131 - 139.

165. Aernoudt J 1999 European policy towards venture capital: Myth or reality? Venture Capital 1 (1) pp 47 - 57.

166. Bliss R 1999 A venture capital model for transitioning economies: The case of Poland venture capital International Journal of Entrepreneurial Finance 1 (3) pp 241 - 257.

167. Bygrave W D, Hay M, Peeters J B 1999 The venture capital handbook Financial Times Prentice Hall London UK.

168. Gilson R 1999 The legal infrastructure of high technology industrial districts: Silicon Valley Route 128, and covenants not to compete York University Law Review 74 pp $575-629$.

169. Gilson R, Schizer D 2003 Understanding venture capital structure: A tax explanation for convertible preferred stock Harvard Law Review 116 pp 874 - 916.

170. Gulati R, Gargiulo M 1999 Where do inter-organizational networks come from? American Journal of Sociology vol 104 (5) pp 1439-1493 University of Chicago Press Chicago USA.

171. Hamao Y, Packer F, Ritter J R 1999 Institutional affiliation and the role of venture capital: Evidence from initial public offerings in Japan Marshall School of Business University of Southern California Capital Markets Department Federal Reserve Bank of New York Warrington College of Business Administration University of Florida USA pp 1 - 50.

172. Leopold G 1999 Venture capital - das eigenkapitalgeschaft mit kleinen und mittleren unternehmen Deutsches Steuerrecht 37 pp 470 - 476.

173. Neher D 1999 Staged financing: An agency perspective Review of Economic Studies 66 pp 255 - 274.

174. Shepherd D A 1999 Venture capitalists' assessment of new venture survival Management Science 45 (5) pp 621 - 632.

175. Shepherd D A, Zacharakis A 1999 Conjoint analysis: A new methodology for researching the decision policies of venture capitalists Venture Capital 1 pp 197 - 217.

176. Stillman R, Sunderland J, Heyl L, Swart H 1999 A venture capital programme for South Africa: Study and recommendations Nathan Associates Working Paper Arlington Virginia USA.

177. Baygan G, Freudenberg M 2000 The internationalization of venture capital activity in OECD countries: Implications for measurement and policy OECD Science, Technology and Industry Working Papers 2000/07 OECD Publishing pp 1 - 55 http://dx.doi.org/10.1787/084236411045 . 
178. Baygan G 2003 Venture Capital Policies in Korea OECD Science, Technology and Industry Working Papers 2003/02 OECD Publishing Directorate for Science, Technology and Industry Organization for Economic Co-operation and Development pp 1 - 21 http://www.oecd.org/sti/working-papers http://dx.doi.org/10.1787/248000716362 .

179. Bharat A, Galetovic A 2000 Weak property rights and holdup in R\&D Journal of Economics and Management Strategy 9 pp 615 - 642.

180. Cumming D J 2000 The convertible preferred equity puzzle in Canadian venture capital finance Working Paper University of Alberta on www.ssrn.com .

181. Cumming D J 2001 The determinants of venture capital portfolio size: Empirical evidence Working Paper University of Alberta www.ssrn.com .

182. Cumming D J, MacIntosh J G 2000 Venture capital exits in Canada and the United States University of Toronto Law Journal 2003 www.ssrn.com .

183. Cumming D J, MacIntosh J G 2001 Venture capital investment duration in Canada and the United States Journal of Multinational Financial Management 11 pp 445 - 463.

184. Cumming D J, MacIntosh J G 2002a Crowding out private equity: Canadian evidence Working Paper University of Alberta and University of Toronto www.ssrn.com .

185. Cumming D J, MacIntosh J G 2002b A cross-country comparison of full and partial venture capital exits Journal of Banking and Finance www.ssrn.com .

186. Cumming D J, MacIntosh J G 2002c The extent of venture capital exits: Evidence from Canada and the United States in McCahery J, Renneboog L D R (editors) Venture capital contracting and the valuation of high-tech firms Oxford University Press www.ssrn.com .

187. Cumming D J, MacIntosh J G 2002d Economic and institutional determinants of venture capital investment duration in Libecap G (editor) Advances in the study of entrepreneurship innovation and economic growth JAI Press.

188. Cumming D, Fleming G 2002 A law and finance analysis of venture capital exits in emerging markets Working Paper Series in Finance 02-03 The Australian National University Canberra Australia.

189. Cumming D, MacIntosh J G 2003a A cross-country comparison of full and partial venture capital exits Journal of Banking and Finance 27 pp 511 - 548.

190. Cumming D J, MacIntosh J F 2003b Comparative venture capital governance: private versus labour sponsored venture capital funds CESifo Working Paper no 8532002 CESifo Area Conference on Venture Capital, Entrepreneurship and Public Policy pp 1 - 41.

191. Cumming D, Fleming G, Schwienbacher A, 2005 Liquidity risk and venture capital finance Financial Management 34 pp 77 - 105. 
192. Cumming D, Fleming G, Suchard J 2005 Venture capitalist value-added activities, fundraising and drawdowns Journal of Banking and Finance 29 pp 295 - 331.

193. Cumming D, Fleming G, Schwienbacher A 2006 Legality and venture capital exits Journal of Corporate Finance 12 pp 214 - 245.

194. Cumming D, MacIntosh J 2006 Crowding out private equity: Canadian evidence Journal of Business Venturing 21 pp 569 - 609.

195. Cumming D 2008 Contracts and exits in venture capital finance Review of Financial Studies 21 pp 1947 - 1982.

196. Cumming D, Johan 2008 Preplanned exit strategies in venture capital European Economic Review 52 pp 1209 - 1241.

197. Cumming D, Fleming G, Schwienbacher A 2009 Style drift in private equity Journal of Business Finance and Accounting 36 pp 645 -678.

198. Cumming D, Walz U 2010 Private equity returns and disclosure around the world Journal of International Business Studies 41 pp 727 - 754.

199. Gans J, Stern S 2000 Incumbency and R\&D incentives: Licensing the gale of creative destruction Journal of Economics and Management Strategy 9 pp 485 - 511.

200. Gans J, Hsu D, Stern S 2002 When does start-up innovation spur the gale of creative destruction? RAND Journal of Economics 33 pp 571 - 586.

201. Gans J, Stern S 2003 When does funding research by smaller firms bear fruit? Evidence from the SBIR program Economics of Innovation and New Technology 16 pp 361 - 384.

202. Jain A, Kini O 2000 Does the presence of venture capitalists improve the survival profile of IPO firms? Journal of Business Finance and Accounting vol 27 issues 9, 10 pp 1139-1176.

203. Jeng L, Wells P 2000 The determinants of venture capital funding: Evidence across countries Journal of Corporate Finance 6 pp 241 - 289.

204. Kaplan S, Strömberg P 2000 Financial contracting theory meets the real world: An empirical analysis of venture capital contracts NBER Working Paper no 7660.

205. Kaplan S, Strömberg P 2001 Venture capitalists as principals: Contracting, screening, and monitoring American Economic Review 91 pp 426 - 430.

206. Kaplan S, Strömberg P 2002 Financial contracting theory meets the real world: An empirical analysis of venture capital contracts Review of Economic Studies vol 70 no 2 pp $281-315$.

207. Kaplan S, Strömberg P 2003 Financial contracting theory meets the real world: An empirical analysis of venture capital contracts Review of Economic Studies $\mathbf{7 0}$ pp 281 - 315. 
208. Kaplan S, Strömberg P 2004 Characteristics, contracts, and actions: Evidence from venture capitalist analyses Journal of Finance 59 pp 2177 - 2210.

209. Kaplan S, Schoar A 2005 Private equity performance: returns, persistence, and capital flows Journal of Finance $\mathbf{6 0}$ pp 1791 - 1823.

210. Kaplan S, Martel F, Strömberg P 2007 How do legal differences and experience affect financial contracts? Journal of Financial Intermediation 16 pp 273 - 311.

211. Kaplan S, Strömberg P 2009 Leveraged buyouts and private equity Journal of Economic Perspectives 23 pp 121 - 146.

212. Kaplan S, Sensoy B, Strömberg P 2009 Should investors bet on the jockey or the horse? Evidence from the evolution of firms from early business plans to public companies Journal of Finance 64 pp 75 - 115.

213. Kaplan S, Lerner J 2010 It ain't broke: The past, present, and future of venture capital Journal of Applied Corporate Finance 22 pp 36 - 47.

214. Karaömerlioğlu D Ç, Jacobsson S 2000 The Swedish venture capital industry - an infant, adolescent or grown-up? Venture Capital 2 pp 61 - 68.

215. Koski T 2000 Success potential of a venture capital investment. A model to simulate venture capitalists' perception using fuzzy set theory PhD Dissertation A-177 HeSE Print Helsinki School of Economics and Business Administration Helsinki Finland.

216. Lee J 2000 Challenges of Korean technology-based ventures and governmental policies in the emergent-technology sector Technovation $\mathbf{2 0 .}$

217. Lehtonen S 2000 Venture capitalist's exit vehicles and their effects on perceived utility. Allocation of rewards and contract structure PhD Dissertation no 89 Swedish School of Economics and Business Administration Helsingfors Sweden.

218. Quindlen R 2000 Confessions of a venture capitalist: Inside the high-stakes world of new venture financing Warner Books New York USA.

219. Schefczyk M 2000 Erfolgsstrategien deutscher venture capital - gesellschaften $2^{\text {nd }}$ edition Schaeffer-Poeschel Stuttgart Germany.

220. Schertler A 2000 The impact of public subsidies on venture capital investments in startup enterprises Kiel Working Paper no 1018 p 23.

221. Bascha A, Walz U 2001 Convertible securities and optimal exit decisions in venture capital finance Journal of Corporate Finance 7 pp 285 - 306.

222. Engel D 2001a Höheres beschäftigungswachstum durch venture capital? ZEW Discussion Paper no 01-34 Mannheim Germany. 
223. Engel D 2001b Die identifizierung VC-finanzierter unternehmen in den ZEW Gründungspanels Unveröffentlichtes Manuskript Mannheim Germany.

224. Engel D 2002 Welche regionen profitieren von venture capital - aktivitäten? ZEW Discussion Papers no 02-37 http://hdl.handle.net/10419/24770 ftp://ftp.zew.de/pub/zewdocs/dp/dp0237.pdf .

225. Francis B B, Hasan I 2001 The underpricing of venture and non-venture capital IPOs: An empirical investigation Journal of Financial Services Research 19 pp 93 - 113.

226. Fredriksen $\varnothing$, Klofsten M 2001 Venture capitalists' governance of their portfolio companies Journal of Enterprising Culture 9 pp 201 - 219.

227. Hyytinen A, Pajarinen M 2001 Financial systems and venture capital in Nordic Countries: A comparative study Discussion Paper 774 The Research Institute of the Finnish Economy Helsinki Finland.

228. Keuschnigg Ch, Nielsen S B 2001 Public policy for venture capital International Tax and Public Finance 8 (4) pp 557 - 572.

229. Keuschnigg Ch 2003 Optimal public policy for venture capital backed innovation CEPR DP 3850.

230. Keuschnigg Ch, Nielsen S B 2003a Tax policy, venture capital, and entrepreneurship Journal of Public Economics 87 (1) pp 175 - 203.

231. Keuschnigg C, Nielsen S B 2003b Taxes and venture capital support European Finance Review 7 pp 515 - 539.

232. Keuschnigg, Ch 2004a Taxation of a venture capitalist with a portfolio of firms Oxford Economic Papers 56 (1) pp 285 - 306.

233. Keuschnigg Ch 2004b Venture capital backed growth Journal of Economic Growth 9 (2) pp 239 - 261.

234. Kanniainen V, Keuschnigg Ch 2004 Start-up investment with scarce venture capital support Journal of Banking and Finance 28 pp 1935 - 1959.

235. Keuschnigg Ch, Nielsen S 2004a Start-ups, venture capitalists, and the capital gains tax Journal of Public Economics 88 pp 1011 - 1042.

236. Keuschnigg C, Nielsen S B 2004b Taxation and venture capital backed entrepreneurship International Tax and Public Finance 11 pp 369 - 390.

237. Kirilenko A 2001 Valuation and control in venture finance Journal of Finance 56 pp 565 - 587.

238. Lockett A, Wright M 2001 The syndication of venture capital investments Omega The International Journal of Management Science 29 pp 375 - 390. 
239. Maula M, Murray G 2001 Corporate venture capital and the creation of US public companies in Hitt A, Amit R, Lucier C, Nixon D (editors) Creating value: Winners in the new business environment Blackwell New York USA.

240. Peng L 2001 Building a venture capital index Social Science Research Network Electronic Paper Collection Economics Department Yale University pp 1 - 54 http://paper.ssrn.com/abstract=281804 .

241. Seppä T J, Laamanen T 2001 Valuation of venture capital investments: Empirical evidence $R \& D$ Management vol 31 (2) pp 215 - 230.

242. Seppä T J 2003 Essays on the valuation and syndication of venture capital investments PhD Dissertation 2003/1 Espoo Finland.

243. Shachmurove Y 2001 Annualized returns of venture-backed public companies categorized by stage of financing Journal of Entrepreneurial Finance vol 6 no 1 pp 44 - 58.

244. Shachmurove Y 2007a Innovation and trade: Introduction and comments in Sheshinski E, Strom R J, Baumol W J (editors) Entrepreneurship, innovation, and the growth mechanism of the free-enterprise economies Princeton University Press pp 247 - 260.

245. Shachmurove Y 2007b Geography and industry meets venture capital Departments of Economics The City College of the City University of New York University of Pennsylvania USA pp 1- 34 http://ssrn.com/abstract=977989 .

246. Shachmurove A, Shachmurove Y 2004 Annualized and cumulative returns on venturebacked public companies categorized by industry The Journal of Entrepreneurial Finance and Business Ventures vol 9 issue 3 pp 41 - 60.

247. Shachmurove E, Shachmurove Y 2004 Annualized returns of ventured-backed public companies stratified by decades and by stage of financing The Journal of Entrepreneurial Finance and Business Ventures vol 9 issue 2 pp 109 - 123.

248. Sorenson O, Stuart T 2001 Syndication networks and the spatial distribution of venture capital investments American Journal of Sociology 106 pp 1546 - 1588.

249. Allen F, Song W 2002 Venture capital and corporate governance http://fic.wharton.upenn.edu/fic/papers/03/0305.pdf .

250. Audretsch D, Lehmann E 2002 Debt or equity? The role of venture capital in financing the new economy Germany CEPR Working Paper no 3656.

251. Bottazzi L, Da Rin M 2002a Venture capital in Europe and the financing of innovative companies Economic Policy 34 pp 229 - 269.

252. Bottazzi L, Da Rin M 2002b Europe's "New" stock markets CEPR Discussion Paper no 3521 . 
253. Bottazzi L, Da Rin M, Giavazzi F 2003 Research, patents, and the financing of ideas: Why is the EU growth potential so low?' in Sapir A, Nava M (editors) Economic policymaking in the European Union European Commission Brussels Belgium.

254. Bottazzi L, Da Rin M 2004 Financing European entrepreneurial firms: Facts, issues and research agenda in Keuschnigg Ch, Kanniainen V (editors) Venture capital, entrepreneurship and public policy Cambridge MA MIT Press USA.

255. Bottazzi L, Da Rin M, Hellmann T 2004a The changing face of the European venture capital industry: Facts and analysis Journal of Private Equity 7 pp 26 - 53.

256. Bottazzi L, Da Rin M, Hellmann Th 2004b Active financial intermediation: Evidence on the role of organizational specialization and human capital RICAFE Working Paper no 12.

257. Bottazzi L, Da Rin M, Hellmann T 2008 Who are the active investors? Evidence from venture capital Journal of Financial Economics 89 pp 488 - 512.

258. Bottazzi L, Da Rin M, Hellmann T 2009 What is the role of legal systems in financial intermediation? Theory and evidence Journal of Financial Intermediation 18 pp 559 - 598.

259. Brander J, Amit R, Antweiler W 2002 Venture capital syndication: Improved venture selection versus value-added hypothesis Journal of Economics and Management Strategy 11 pp 423 - 452.

260. Brander J, Egan E, Hellmann T 2008 Government sponsored versus private venture capital: Canadian evidence in Lerner J and Schoar A (editors) NBER Conference Volume on International Differences in Entrepreneurship.

261. Brander J, De Bettignies J 2009 Venture capital investment: the role of predator-prey synamics with learning by doing Economics of Innovation and New Technology 18 pp 1 - 19.

262. Brander J, Du Q, Hellmann T 2010 Governments as venture capitalists: Striking the right balance in Globalization of alternative investments vol 3 The global economic impact of private equity report 2010 World Economic Forum Davos Switzerland.

263. Chesbrough H W 2002 Making sense of corporate venture capital Harvard Business Review 80 (3) pp 4 - 11.

264. Cestone G 2002 Venture capital meets contract theory: Risky claims or formal control? CEPR Discussion Paper 3462.

265. Davis M, Schachermayer W, Tompkins R 2002 The evaluation of venture capital as an instalment option: Valuing real options using real options pp 1 - 31.

266. Dossani R, Kenney M 2002 Creating an environment for venture capital in India World Development 30 (2) pp 227 - 253. 
267. Eisele F, Habermann M, Oesterle R 2002 Die beteiligungskriterien fur eine venture capital finanzierung - eine empirische analyse der phasenbezogenen bedeutung Tubinger Diskussionsbeitrag no 238 Germany pp 1 - 35.

268. Everts M 2002 Cash dilution in illiquid funds MPRA Paper no 4655 Munich University Munich Germany pp 1 - 15 http://mpra.ub.uni-muenchen.de/4655/ .

269. Gilson R, Schizer D 2002 Understanding venture capital structure: A tax explanation for convertible preferred stock Columbia Law School Working Paper no 230 Columbia University New York USA.

270. Kenney M, Han K, Tanaka S 2002 Scattering geese: The venture capital industries of East Asia A Report to the World Bank BRIE Working Paper 146 Berkeley California USA http://brie.berkeley.edu/publications/wp146.pdf .

271. Koh F C C, Koh W T H 2002 Venture capital and economic growth: An industry overview and Singapore's experience Working Paper no $21 \quad$ - 2002 http://www.research.smu.edu.sg/faculty/edge/entrep_fin/papers/SERVCandGrowth_WP_dec _2002.pdf .

272. McGlue D 2002 The funding of venture capital in Europe: Issues for public policy Venture Capital 4 (1) pp 45 - 58.

273. Moskowitz T, Vissing-Jørgensen A 2002 The returns to entrepreneurial investment: A private equity premium puzzle? American Economic Review 92 pp 745 - 778.

274. Shane S, Cable D 2002 Network ties, reputation, and the financing of new ventures Management Science 48 (3) pp 364 - 381.

275. Shane S, Stuart T 2002 Organizational endowments and the performance of university start-ups Management Science 48 pp 154 - 170.

276. Zook M 2002 Grounded capital: Venture financing and the geography of the Internet industry, 1994-2000 Journal of Economic Geography 2 pp 151 - 177.

277. Brav A, Gompers P 2003 The role of lockups in Initial Public Offerings Review of Financial Studies 16 pp 1 - 29.

278. Becker R, Hellman $\mathrm{T} 2003$ The genesis of venture capital: Lessons from the German experience CESifo Working Paper no 883 Sauder School of Business.

279. Bergemann D, Hege U 2003 The value of benchmarking in McCahery J A, Renneboog L (editors) Venture capital contracting and the valuation of high tech firms Oxford University Press Oxford UK pp 83 - 107.

280. Casamatta C 2003 Financing and advising: optimal financial contracts with venture capitalists Journal of Finance 58 pp 2059 - 2086. 
281. Casamatta C, Haritchabalet C 2007 Experience, screening and syndication in venture capital investments Journal of Financial Intermediation 16 pp 368 - 398.

282. Cornelli F, Yosha O 2003 Stage financing and the role of convertible securities Review of Economic Studies 70 pp 1 - 32.

283. Davila A, Foster G, Gupta M 2003 Venture capital financing and the growth of start-up firms Journal of Business Venturing 18 pp 689 - 708.

284. Franzke S A, Grohs S, Laux Ch 2003 Initial public offerings and venture capital in Germany CFS Working Paper no 2003/26 Center for Financial Studies an der Johann Wolfgang Goethe-Universität Frankfurt am Main Leibniz Information Centre for Economics Germany pp 1 - 39 http://hdl.handle.net/10419/25395 www.ifk-cfs.de www.econstor.eu.

285. Gawlik R, Teczke J 2003 Spin of enterprises as a financing solution for the innovative clients of science and technology parks MPRA Paper no 45224 Munich University Munich Germany pp 1 - 7 http://mpra.ub.uni-muenchen.de/45224/.

286. Gilson R, Schizer D 2003 Venture capital structure: A tax explanation for convertible preferred stock Harvard Law Review 116 pp 875 - 916.

287. Hirukawa M, Ueda M 2003 Venture capital and productivity University of WisconsinMadison USA.

288. Inderst R, Muller H 2003 The effect of capital market characteristics on the value of startup firms Journal of Financial Economics 72 pp 319 - 356.

289. Keilbach M, Engel D 2003 Firm level implications of early stage venture capital investment: An empirical investigation ZEW Discussion Papers no 02-82 Leibniz Information Centre for Economics Germany p 1 - 25 http://hdl.handle.net/10419/23962 ftp://ftp.zew.de/pub/zew-docs/dp/dp0282.pdf www.econstor.eu.

290. Nielsen S B, Keuschnigg Ch 2006 Public policy, start-up entrepreneurship, and the market for venture capital Working Paper 15-06 Department of Economics Copenhagen Business School Copenhagen Denmark pp 1 - 43.

291. Leleux B, Surlemont B 2003 Public versus private venture capital: seeding or crowding out? A pan-European analysis Journal of Business Venturing 18 pp 81 - 104.

292. Rindermann G 2003 Venture capitalist participation and the performance of IPO firms: Empirical evidence from France, Germany and the UK EFMA 2003 Helsinki Meeting Finland.

293. Schmidt K 2003 Convertible securities and venture capital finance Journal of Finance $\mathbf{5 8}$ pp 1139 - 1166. 
294. Schmidt D, Wahrenburg M 2003 Contractual relations between European - VC funds and investors: The impact of reputation and bargaining power on contractual design RICAFE Working Paper 12 http://ww.lse.ac.uk/ricafe.

295. Schertler A 2003 Driving forces of venture capital investments in Europe: A dynamic panel data analysis. European Integration. Financial Systems and Corporate Performance EFIC Working Paper no 03-27 United Nations University.

296. Stuart T, Sorenson O 2003 Liquidity events and the geographic distribution of entrepreneurial activity Administrative Science Quarterly 48 pp 175 - 201.

297. Wang C K, Wang K, Lu Q 2003 Effects of venture capitalists' participation in listed companies Journal Banking Finance 27 pp 2015 - 2034.

298. Wasserman N 2003 Founder-CEO succession and the paradox of entrepreneurial success Organization Science 14 pp 149 - 172.

299. Wasserman N 2006 Stewards, agents, and the founder discount: Executive compensation in new ventures Academy of Management Journal 49 pp 960 - 976.

300. Woodward S, Hall R 2003 Benchmarking the returns to venture NBER Working Paper 10202 http://www.nber.org/papers/w10202.

301. Aghion P, Bolton P, Tirole J 2004 Exit options in corporate finance: Liquidity versus incentives Review of Finance $\mathbf{8}$ pp 327 - 353.

302. Avnimelech G, Kenney M, Teubal M 2004 Building venture capital industries: understanding the US and Israeli experiences Berkeley Roundtable on the International Economy UC Berkeley USA.

303. Avnimelech G, Teubal M 2004 Venture capital start-up co-evolution and the emergence \& development of Israel's new high tech cluster Economics of Innovation \& New Technology 13 (1) pp 33 - 60.

304. Audretsch D B, Keilbach M 2004 Entrepreneurship capital and economic performance Regional Studies 38 (8) pp 949 - 959.

305. Baum J, Silverman B 2004 Picking winners or building them? Alliances, patents, and human capital as selection criteria in venture financing of biotechnology startups Journal of Business Venturing 19 pp 411 - 436.

306. Berk J, Green R, Naik V 2004 Valuation and return dynamics of new ventures Review of Financial Studies 17 pp 1 - 35.

307. Da Rin M, Nicodano G, Sembenelli A 2004 Public policy and the creation of active venture capital markets Working Paper no 270 IGIER - Università Bocconi Italy pp 1 - 38 http://www.igier.uni-bocconi.it . 
308. Dittmann I, Maug E, Kemper J 2004 How fundamental are fundamental values? Valuation methods and their impact on the performance of German venture capitalists European Financial Management vol 10 (4) pp 609 - 638.

309. Hsu D 2004 What do entrepreneurs pay for venture capital affiliation? Journal of Finance 59 pp 1805 - 1844.

310. Inderst R, Müller H 2004 The effect of capital market characteristics on the value of startup firms Journal of Financial Economics 72 pp 319 - 356.

311. Inderst $\mathrm{R}$, Müller $\mathrm{H}$, Muennich $\mathrm{F} 2007$ Financing a portfolio of projects Review of Financial Studies 20 pp 1289 - 1325.

312. Inderst R, Müller H 2009 Early-stage financing and firm growth in new industries Journal of Financial Economics 93 pp 276 - 291.

313. Jones C M, Rhodes-Kropf M 2004 The price of diversifiable risk in venture capital and private equity pp $1-53$.

314. Lee P, Wahal S 2004 Grandstanding, certification and the underpricing of venture capital backed IPOs Journal of Financial Economics 73 pp 375 - 407.

315. Michelacci C, Suarez J 2004 Business creation and the stock market Review of Economic Studies 71 pp 459 - 481.

316. Mishra A 2004 Indian venture capitalists (VCs): Investment evaluation criteria ICFAI Journal of Applied Finance 10 (7) pp 71 - 93.

317. Peggy M L, Wahal S 2004 Grandstanding, certification and the underpricing of venture capital backed IPOs Journal of Financial Economics 73 pp 375 - 407.

318. Repullo R, Suarez J 2004 Venture capital finance: A security design approach Review of Finance 8 pp 75 - 108.

319. Roman A, van Pottelsberghe de la Potterie B 2004 The determinants of venture capital: A panel analysis of 16 OECD countries Working paper WF CEB 04/015 Universite Libre de Bruxelles Brussels Belgium.

320. Sternberg R J 2004 Successful intelligence as a basis for entrepreneurship Journal Business Venture 19 pp 189 - 201.

321. Ueda M 2004 Banks versus venture capital: Project evaluation, screening, and expropriation Journal of Finance 59 pp 601 - 621.

322. Becker R, Hellmann $\mathrm{T} 2005$ The genesis of venture capital: Lessons from the German experience in Keuschnigg C, Kanniainen V (editors) Venture capital, entrepreneurship, and public policy Chapter 2 MIT Press Massachusetts Institute of Technology USA pp 33 - 67. 
323. Bergemann D, Hege $\mathrm{U} 2005$ The financing of innovation: learning and stopping RAND Journal of Economics 36 pp 719 - 752.

324. Cochrane $\mathrm{J} 2005$ The risk and return of venture capital Journal of Financial Economics 75 pp $3-52$.

325. Da Rin M, Hege M U, Llobet G, Walz U 2005 The law and finance of venture capital financing in Europe: Findings from the RICAFE research project MPRA Paper no 39552 Munich University Munich Germany pp 1 - 30 http://mpra.ub.uni-muenchen.de/39552/ .

326. Da Rin M, Nicodano G, Sembenelli A 2005, 2006 Public policy and the creation of active venture capital markets Journal of Public Economics 90 pp 1699 - 1723 http://www.ecb.int http://ssrn.com/abstract_id=634025 .

327. Da Rin M, Hellmann Th, Puri M 2011 A survey of venture capital research TILEC Discussion Paper no 2011-044 CentER Discussion Paper no 2011-111 Tilburg University Tilburg Netherlands University of British Columbia Vancouver British Columbia Canada Duke University Durham North Carolina USA ISSN 0924-7815 pp 11 - 136 http://ssrn.com/abstract=1942821.

328. De Carvalho A G, Calomiris C W, De Matos J A 2005 Venture capital as human resource management NBER Working Paper no 11350.

329. Dessein W 2005 Information and control in ventures and alliances Journal of Finance 60 pp $2513-2549$.

330. Dessí R 2005 Start-up finance, monitoring and collusion RAND Journal of Economics 36 pp 255 - 274.

331. Dimov D, Shepherd D 2005 Human capital theory and venture capital firms: Exploring "home runs" and "strike outs"” Journal of Business Venturing 20 pp 1 - 21.

332. Dushnitsky G, Lenox M 2005a When do firms undertake R\&D by investing in new ventures? Strategic Management Journal 26 pp 947 - 965.

333. Dushnitsky G, Lenox M J 2005b When do incumbents learn from entrepreneurial ventures? Corporate venture capital and investing firm innovation rates Research Policy 34 pp $615-639$.

334. Dushnitsky G, Lenox M J 2006 When does corporate venture capital create firm value? Journal of Business Venturing 21 pp 753 - 772.

335. Dushnitsky G, Lavie D 2008 Interdependence in the evolution of inter-firm networks: How alliances shape corporate venture capital in the software industry 2007 West Coast Research Symp on Technology Entrepreneurship University of Washington Seattle USA. 
336. Ernst H, Witt P, Brachtendorf G 2005 Corporate venture capital as a strategy for external innovation: An exploratory empirical study R\&D Management 25 pp 233-242.

337. Ge D, Mahoney J M, Mahoney J T 2005 New venture valuation by venture capitalists: An integrative approach Federal Reserve Bank of New York NY USA.

338. Hsu D, Kenney M 2005 Organizing venture capital: The rise and demise of American Research \& Development Corporation, 1946-1973 Industrial and Corporate Change 14 pp 579 - 616.

339. Hsu D 2006 Venture capitalists and cooperative start-up commercialization strategy Management Science 52 pp 204 - 219.

340. Hsu D 2007 Experienced entrepreneurial founders, organizational capital, and venture capital funding Research Policy 36 pp 722 - 741.

341. Klepper S, Sleeper S 2005 Entry by spinoffs Management Science 51 pp 1291 - 1306.

342. Klepper S, Thompson P 2010 Disagreements and intra-industry spinoffs International Journal of Industrial Organization 28 pp 526 - 538.

343. Kõomägi M 2005a Riskikapitaliinvesteeringud eestis. Haridus ja majandus Rahvusvahelise teaduskonverentsi materjalid Tallinn Estonia pp 53 - 56.

344. Kõomägi M 2005b Venture capital financing and deal structuring problems in Estonia. Business development possibilities in the new European area Scientific Proceedings Part 1 Vilnius Lithuania pp 125 - 130.

345. Kõomägi M 2005c Riskikapitali hinnakujunemise mehhanism. Eesti ettevõtluse perspektiivid Euroopa liidus Pärnu Mattimar OÜ Tallinn-Pärnu Estonia pp 94 - 110.

346. Kõomägi M, Sander P 2006 Venture capital investments and financing in Estonia: A case study approach Tartu University Press Faculty of Economics and Business Administration University of Tartu Estonia ISSN 1406-5967 ISBN 9949-11-264-8 pp 1 - 77 www.tyk.ee .

347. Lai R 2005 Does competition kill ties? MPRA Paper no 4759 Munich University Munich Germany pp 1 - 37 http://mpra.ub.uni-muenchen.de/4759/ .

348. Mäkelä M M, Maula M M 2005 Cross-border venture capital and new venture internationalization: An isomorphism perspective Venture Capital vol 7 no 3 pp 227 - 257.

349. Mayer C, Schoors K, Yafeh Y 2005 Sources of funds and investment activities of venture capital funds: Evidence from Germany, Israel, Japan and the United Kingdom Journal of Corporate Finance 11 pp 586 - 608.

350. Neus W, Walz U 2005 Exit timing of venture capitalists in the course of an initial public offering Journal of Financial Intermediation 14 pp 253 - 277. 
351. Wong L H 2005 Venture capital fund management: A comprehensive approach to investment practices and the operations of a VC firm Aspatore Books Singapore pp 1 - 485.

352. Zook M A 2005 The geography of the Internet industry: Venture capital, dotcoms, and local knowledge Blackwell Publishing Malden MA USA.

353. Antonelli C, Teubal M 2006 Venture capitalism as a mechanism for knowledge governance Working paper series no 4 Department of Economics Università di Torino Italy.

354. Cassiman B, Ueda M 2006 Optimal project rejection and new firm start-ups Management Science 52 pp $262-275$.

355. Colombo M, Grilli L, Piva E 2006 In search of complementary assets: the determinants of alliance formation of high-tech start-ups Research Policy 35 pp 1166 - 1199.

356. Dimov D, De Clercq D 2006 Venture capital investment strategy and portfolio failure rate: A longitudinal study Entrepreneurship Theory and Practice vol 30 no 2 pp 207 - 223.

357. Eckhardt J, Shane S, Delmar F 2006 Multistage selection and the financing of new ventures. Management Science 52 pp 220 - 232.

358. Ellul A, Pagano M 2006 IPO underpricing and after-market liquidity Review of Financial Studies 19 pp 381 - 421.

359. Gebhardt G, Schmidt K 2006 Conditional allocation of control rights in venture capital firms CEPR Discussion Paper 5758.

360. Fallick B, Fleischman C, Rebitzer J 2006 Job-hopping in Silicon Valley: Some evidence concerning the microfoundations of a high-technology cluster Review of Economics and Statistics 88 pp 472 - 481.

361. Franco A, Filson D 2006 Spinouts: Knowledge diffusion through employee mobility RAND Journal of Economics 37 pp 841 - 860.

362. Franco A, Mitchell M 2008 Covenants not to compete, labor mobility, and industry dynamics Journal of Economics and Management Strategy 17 pp 581 - 606.

363. Isaksson A 2006 Studies on the venture capital process PhD Thesis Umeå University Sweden.

364. Mathews R 2006 Strategic alliances, equity stakes, and entry deterrence Journal of Financial Economics 80 pp 35 - 79.

365. Motohashi K $2006 \mathrm{R} \& \mathrm{D}$ networks of small and medium size companies in Goto and Kodama editors Innovation system in Japan University of Tokyo Press (in Japanese) Tokyo Japan pp 137 - 167. 
366. Motohashi K 2010 Comparative analysis of biotechnology startups between Japan and the US MPRA Paper no 50095 Munich University Munich Germany pp 1 - 25 http://mpra.ub.uni-muenchen.de/50095/ .

367. Proimos A, Murray W 2006 Entrepreneuring into venture capital The Journal of Private Equity 9 (3) pp 23 - 34 doi: 10.3905/jpe.2006.635426.

368. Riyanto Y, Schwienbacher A 2006 On the strategic use of corporate venture financing for securing demand Journal of Banking and Finance 31 pp 679 - 702.

369. Tirole J 2006 The theory of corporate finance Princeton University Press New Jersey USA.

370. Wadhwa A, Kotha S 2006 Knowledge creation through external venturing: Evidence from the telecommunications equipment manufacturing industry Academy of Management Journal 49 (4) pp 819 - 835.

371. Zhang J 2006 A study of academic entrepreneurs using venture capital data Working Paper no 2006.01 Public Policy Institute of California San Francisco California USA.

372. Zhang J 2007a Access to venture capital and the performance of venture capital-backed star-ups in Silicon Valley Economics Developments Quarterly 21 pp 124 - 147.

373. Zhang $\mathrm{J}$ 2007b The advantage of experienced start-up founders in venture capital acquisition: Evidence from serial entrepreneurs IZA Discussion Paper no 2964 Department of Economics Clark University USA pp 1 - 42.

374. Bernile G, Cumming D, Lyandres E 2007 The size of venture capital and private equity fund portfolios Journal of Corporate Finance 13 pp 564 - 590.

375. Campbell R A, Kraeussl R 2007 A survey of the venture capital industry in Central and Eastern Europe in Gregoriou G N, Kooli M, Kraeussl R (editors) Venture capital in Europe Chapter 4 Elsevier - North Holland Quantitative Finance Series New York USA.

376. Colombo L, Dawid H, Kabus K 2007 When do Thick Venture Capital Markets Foster Innovation? An Evolutionary Analysis IEF0074 - marzo - 2007 Istituto di Economia e Finanza Università Cattolica del Sacro Cuore Milano Italy pp 1 - 31.

377. de Bettignies J-E, Brander J 2007 Financing entrepreneurship: Bank finance versus venture capital Journal of Business Venturing 22 pp 808 - 832.

378. de Bettignies J-E, Chemla G 2008 Corporate venturing, allocation of talent, and competition for star managers Management Science 54 pp 505 - 521.

379. de Bettignies J-E 2008 Financing the entrepreneurial venture Management Science 54 pp $151-166$. 
380. Engel D, Keilbach M 2007 Firm level implications of early stage venture capital investments: An empirical investigation Journal of Empirical Finance 14 pp 150 - 167.

381. Hochberg Y, Ljungqvist A, Lu Y 2007 Whom you know matters: Venture capital networks and investment performance Journal of Finance 62 pp 251-301.

382. Hochberg Y, Ljungqvist A, Lu Y 2010 Networking as a barrier to entry and the competitive supply of venture capital Journal of Finance 65 pp 829 - 859.

383. Hsu D H 2007 Experienced entrepreneurial founders and venture capital funding Research Policy 36 pp 722 - 741.

384. Jovanovic B, Szentes B 2007 On the return to venture capital NBER Working Paper no 12874.

385. Lai R 2007 Why funds of funds? MPRA Paper no 4762 Munich University Munich Germany pp 1- 53 http://mpra.ub.uni-muenchen.de/4762/ .

386. Li K, Prabhala N 2007 Self-selection models in corporate finance in Gecko E (editor) Handbook of corporate finance: Empirical corporate finance vol 1 North Holland Amsterdam The Netherlands.

387. Luukkonen $\mathrm{T} 2007$ Understanding the strategies of venture capital investors in helping their portfolio firms to become international Discussion Paper no 1099 The Research Institute of the Finnish Economy Helsinki Finland ISSN 0781-6847 pp 1 - 28.

388. Luukkonen T 2008 Different types of venture capital investors and value-added to hightech portfolio firms Discussion Paper no 1149 The Research Institute of the Finnish Economy Helsinki Finland ISSN 0781-6847 pp 1 - 28.

389. Mann R, Sager T 2007 Patents, venture capital, and software start-ups Research Policy 36 pp 193 - 208.

390. Pintado T R, De Lema D G P, Van Auken H 2007 Venture capital in Spain by stage of development Journal of Small Business Management 45 (1) pp 68 - 88.

391. Robinson D, Stuart T 2007 Financial contracting in biotech strategic alliances Journal of Law and Economics $\mathbf{5 0}$ pp 559 - 596.

392. Sau L 2007 New pecking order financing for innovative firms: An overview MPRA Paper no 3659 Munich University Munich Germany pp 1- 28 http://mpra.ub.unimuenchen.de/3659/ .

393. Schwienbacher A 2007 A theoretical analysis of optimal financing strategies for different types of capital-constrained entrepreneurs Journal of Business Venturing 22 pp 753 - 781.

394. Schwienbacher A 2008 Innovation and venture capital exits Economic Journal 118 pp 1888 - 1916. 
395. Sørensen M 2007 How smart is smart money? A two-sided matching model of venture capital Journal of Finance 62 pp 2725 - 2762.

396. Tykvová T 2007 Who chooses whom? Syndication, skills, and reputation Review of Financial Economics 16 pp 5 - 28.

397. Aizenman J, Kendall $\mathrm{J} 2008$ The internationalization of venture capital and private equity NBER Working Paper no 14344.

398. Broughman B 2008 Independent directors and board control in venture finance American Law and Economics Association Papers 41 pp 1 - 24.

399. Broughman B, Fried J 2010 Renegotiation of cash flow rights in the sale of VC-backed firms Journal of Financial Economics 95 pp 384 - 399.

400. Cumming D 2008 Contracts and exits in venture capital finance Review of Financial Studies 21 pp 1947 - 1982.

401. Davidsson P, Steffens P R, Gordon S R, Senyard J M 2008 Characteristics of highpotential start-ups: Some early observations from the CAUSEE project http://eprints.qut.edu.au/19649/1/c19649.pdf.

402. Geronikolaou G, Papachristou G 2008 Venture capital and innovation in Europe MPRA Paper no 36706 Munich University Munich Germany pp 1 - 16 http://mpra.ub.unimuenchen.de/36706/, http://ssrn.com/abstract=1309186 .

403. Hand J 2008 Give everyone a prize? Employee stock options in private venture-backed firms Journal of Business Venturing 23 pp 385 - 404.

404. Hirukawa M, Ueda M 2008a Venture capital and industrial innovation CEPR Discussion Paper 7089.

405. Hirukawa M, Ueda M 2008b Venture capital and innovation: Which is first? CEPR Discussion Paper 7090.

406. Katila R, Rosenberger J, Eisenhardt K 2008 Swimming with sharks: Technology ventures and corporate relationships Administrative Science Quarterly 53 pp 295 - 332.

407. Lindsey L 2008 Blurring firm boundaries: The role of venture capital in strategic alliance Journal of Finance $\mathbf{6 3}$ pp 1137 - 1168.

408. McMillan I, Roberts E, Livada V, Wang A 2008 Corporate venture capital: Seeking innovation and corporate growth National Institute for Standards and Technology US Department of Commerce US Government USA.

409. Nahata R 2008 Venture capital reputation and investment performance Journal of Financial Economics 90 pp 127 - 151. 
410. Orman C 2008 Organization of Innovation and Capital Markets MPRA Paper no 23499 Munich University Munich Germany pp 1 - 39 http://mpra.ub.uni-muenchen.de/23499/ .

411. Rossetto S 2008 The price of rapid exit in venture capital-backed IPOs Annals of Finance 4 pp 29 - 53.

412. Schwienbacher A 2008 Innovation and venture capital exits Economic Journal 118 pp $1888-1916$.

413. Schwienbacher A 2009 Venture capital exits in Cumming D (editor) Companion to venture capital Robert W Kolb Companion to finance Series Wiley/Blackwell USA.

414. Sorenson O, Stuart $\mathrm{T} 2008$ Bringing the context back in: Settings and the search for syndicate partners in venture capital investment networks Administrative Science Quarterly 53 pp 266 - 294.

415. Phalippou L 2008 The hazards of using IRR to measure performance: The case of private equity Journal of Performance Measurement 4 pp 55 - 67.

416. Phalippou L, Gottschalg O 2009 The performance of private equity funds Review of Financial Studies 22 pp 1747 - 1776.

417. Puri M, Zarutskie R 2008 On the lifecycle dynamics of venture-capital- and non-venture capital- financed firms EFA 2007 Ljubljana Meetings Paper US Census Bureau Center for Economic Studies Paper no CES-WP-08-13 http://ssrn.com/abstract=967841 .

418. Van Deventer B, Mlambo Ch 2008, 2009 Factors influencing venture capitalists' project financing decisions in South Africa MPRA Paper no 24970 Munich University Munich Germany pp 1 - 10 http://mpra.ub.uni-muenchen.de/24970/ ; South Africa Journal Business Management 40 (1) pp 33 - 41.

419. Winton A, Yerramilli V 2008 Entrepreneurial finance: Banks versus venture capital Journal of Financial Economics 88 pp 51 - 79.

420. Aberman J 2009 The decline of the United States venture capital industry: What the federal government should do about it Amplifier Ventures Washington DC USA.

421. Block J, Sandner $\mathrm{Ph} 2009$ What is the effect of the current financial crisis on venture capital financing? Empirical evidence from US Internet start-ups MPRA Paper no 14727 Munich University Munich Germany pp 1 - 23 http://mpra.ub.uni-muenchen.de/14727/ .

422. Casamatta C 2003 Financing and advising: Optimal financial contracts with venture capitalists Journal of Finance $\mathbf{5 8}$ pp 2059 - 2086.

423. Clarysse B, Knockaert M, Wright M 2009 Benchmarking UK venture capital to the US and Israel: What lessons can be learned? Report prepared for the British Private Equity and Venture Capital Association (BVCA). 
424. Cockburn I, MacGarvie M 2009 Patents, thickets and the financing of early-stage firms: evidence from the software industry Journal of Economics and Management Strategy 18 pp 729 - 773.

425. Fitza M, Matusik S, Mosakowski E 2009 Do VCs matter? The importance of owners on performance variance in start-up firms Strategic Management Journal 30 pp 387 - 404.

426. Fulghieri $P$, Sevilir M 2009a Organization and financing of innovation, and the choice between corporate and independent venture capital Journal of Financial and Quantitative Analysis 44 pp 1291 - 1321.

427. Fulghieri P, Sevilir M 2009b Size and focus of a venture capitalist's portfolio Review of Financial Studies 22 pp 4643 - 4680.

428. Duffner S, Schmid M, Zimmermann H 2009 Trust and success in venture capital financing - an empirical analysis with German survey data Kyklos 62 pp 15 - 43.

429. Hege U, Palomino F, Schwienbacher A 2009 Venture capital performance: The disparity between Europe and the United States MPRA Paper no 39551 Munich University Munich Germany pp 1 - 42 http://mpra.ub.uni-muenchen.de/39551/ .

430. Jones M, Mlambo Ch 2009 Early-stage venture capital in South Africa: Challenges and prospects MPRA Paper no 42890 Munich University Munich Germany pp 1 - 29 http://mpra.ub.uni-muenchen.de/42890/ .

431. Krohmer P, Lauterbach R, Calanog V 2009 The bright and dark side of staging: Investment performance and the varying motivations of private equity Journal of Banking and Finance 33 pp 1597 - 1609.

432. Lingelbach D, Murray G, Gilbert E 2009 The rise and fall of South African venture $\begin{array}{llll}\text { capital: } & \text { A } & \text { co-production } & \text { perspective }\end{array}$ http://papers.ssrn.com/sol3/papers.cfm?abstract_id=1459175 .

433. Litvak K 2009a Venture capital partnership agreements: Understanding compensation arrangements University of Chicago Law Review 76 pp 161 - 218.

434. Litvak K 2009b Governing by exit: Default penalties and walkway options in venture capital partnership agreements Willamette Law Review 40 pp 771 - 812.

435. Masulis R, Nahata R 2009 Financial contracting with strategic investors: Evidence from corporate venture capital backed IPOs Journal of Financial Intermediation 18 pp 599 - 631.

436. Masulis R, Nahata R 2011 Venture capital conflicts of interest: Evidence from acquisitions of venture backed firms Journal of Financial and Quantitative Analysis 46 pp $395-430$. 
437. Norbäck P, Persson L 2009 The organization of the innovation industry: entrepreneurs, venture capitalists, and oligopolists Journal of the European Economic Association 7 pp $1261-1290$.

438. Samuelsson M, Davidsson P 2009 Does venture opportunity variation matter? Investigating systematic differences between innovative and imitative new ventures Small Business Economics 33 (2) pp 229 - 255.

439. Van de Vrande V, Vanhaverbeke W, Duysters G 2009 Additivity and complementarity in external technology sourcing: The added value of corporate venture capital investments MPRA Paper no 26419 pp 1 - 45 Munich University Munich Germany pp 1 - 45 http://mpra.ub.uni-muenchen.de/26419/ .

440. Arikawa Y, Imad'eddine G 2010 Venture capital affiliation with underwriters and the underpricing of initial public offerings in Japan Journal of Economics and Business 62 pp 502 - 516.

441. Benson D, Ziedonis R 2010 Corporate venture capital and the returns to acquiring portfolio companies Journal of Financial Economics 98 pp 478 - 499.

442. Bienz C, Walz U 2010 Venture capital exit rights Journal of Economics and Management Strategy 19 pp 1071 - 1116.

443. Cantner U, Stützer M 2010 The use and effect of social capital in new venture creation: Solo entrepreneurs vs new venture teams Jena Economics Research Papers 12.

444. Cowling M, Murray G, Liu W 2010 An independent econometric analysis of the "Innovation Investment Fund" programme (IIF) of the Australian commonwealth government: Findings and implications Department of Innovation, Industry, Science and Research Canberra Australia.

445. Dushnitsky G, Shapira Z 2010 Entrepreneurial finance meets organizational reality: Comparing investment practices by corporate and independent venture capitalists Strategic Management Journal 31 pp 990 - 1017.

446. Elston J A, Yang J J 2010 Venture capital, ownership structure, accounting standards and IPO underpricing: Evidence from Germany Journal of Economics and Business 62 pp 517 - 536.

447. Groh A, Liechtenstein H 2010 The European venture capital and private equity attractiveness indices Journal of Corporate Finance $\mathbf{1 6}$.

448. Inci E, Barlo M 2010 Banks versus venture capital when the venture capitalist values private benefits of control MPRA Paper no 25566 Munich University Munich Germany pp 1 - 43 http://mpra.ub.uni-muenchen.de/25566/ . 
449. Ivanov V, Xie F 2010 Do corporate venture capitalists add value to start-up firms? Evidence from IPOs and acquisitions of VC-backed companies Financial Management 35 pp $129-152$.

450. Jegadeesh N, Kräussl R, Pollet J 2010 Risk and expected returns of private equity investments: evidence based on market prices NBER Working Paper 15335 USA.

451. Hall R, Woodward S 2010 The burden of the non-diversifiable risk of entrepreneurship American Economic Review 100 pp 1163-1194.

452. Korteweg A, Sørensen M 2010 Risk and return characteristics of venture capital-backed entrepreneurial companies Review of Financial Studies 23 pp 3738 - 3772.

453. Metrick A, Yasuda A 2010 The economics of private equity funds Review of Economic Studies 23 pp 2303 - 2341.

454. Metrick A, Yasuda A 2011 Venture capital and other private equity: A survey European Financial Management 17 pp 619 - 654.

455. Obschonka M, Silbereisen R K, Schmitt-Rodermund E, StuetzerNascent M 2010 Entrepreneurship and the developing individual: Early entrepreneurial competence in adolescence and venture creation success during the career MPRA Paper no 32021 Munich University Munich Germany pp 1 - 36 http://mpra.ub.uni-muenchen.de/32021/ http://www.sciencedirect.com/science/article/pii/S000187911000206X .

456. Stuetzer M, Obschonka M, Davidsson P, Schmitt-Rodermund E 2013 Where do entrepreneurial skills come from? MPRA Paper no 48274 Munich University Munich Germany pp 1 - 10 http://mpra.ub.uni-muenchen.de/48274/ .

457. Samila S, Sorenson O 2010 Venture capital as a catalyst to innovation Research Policy 39 pp $1348-1360$.

458. Samila S, Sorenson O 2011 Venture capital, entrepreneurship, and economic growth Review of Economics and Statistics 93 pp 338 - 349.

459. Schertler A, Tykvová $\mathrm{T} 2010$ What lures cross-border venture capital inflows? ZEW Discussion Papers no 10-001 pp 1 - 36 http://hdl.handle.net/10419/30016 .

460. Sevilir M 2010 Human capital investment, new firm creation and venture capital Journal of Financial Intermediation 19 pp 483 - 508.

461. Zacharakis A, Erikson T, George B 2010 Conflict between the VC and entrepreneur: The entrepreneur's perspective Venture Capital $12 \quad$ (2) pp $109 \quad-126$ doi:10.1080/13691061003771663

462. Zarutskie R 2010 The role of top management team human capital in venture capital markets: Evidence from first-time funds Journal of Business Venturing 25155 - 172. 
463. Ball E, Chiu H, Smith R 2011 Can VCs time the market? An analysis of exit choice for venture-backed firms Review of Financial Studies 243105 - 3138.

464. Bengtsson O, Hand $\mathrm{J} 2011$ CEO compensation in venture capital markets Journal of Business Venturing 26 pp 391 - 411.

465. Bengtsson O, Sensoy B 2011 Investor abilities and financial contracting: Evidence from venture capital Journal of Financial Intermediation 20 pp 477 - 502.

466. Cherif M, Gazdar K 2011 What drives venture capital in Europe? New results from a panel data analysis Journal of Applied Business and Economics 12 (3) pp 122 - 139.

467. Das S, Jo H, Kim Y 2011 Polishing diamonds in the rough: The sources of syndicated venture performance Journal of Financial Intermediation 20 pp 199 - 230.

468. Ferretti R, Meles A 2011 Underpricing, wealth loss for pre-existing shareholders and the cost of going public: The role of private equity backing in Italian IPOs Venture Capital $\mathbf{1 3}$ pp $23-47$.

469. Kandel E, Leshchinskii D, Yuklea H 2011 VC funds: Aging brings myopia Journal of Financial and Quantitative Analysis 46 pp 431 - 457.

470. Kerr W, Nanda R 2011 Financing constraints and entrepreneurship in Audretsch D, Falck O, Heblich S (editors) Handbook on research on innovation and entrepreneurship Edward Elgar Cheltenham UK.

471. Kraeussl R, Krause S 2011 Has Europe been catching up? An industry level analysis of venture capital success over 1985-2009 Document de Travail no 327 Direction Générale des Etudes et des Relations Internationales Banque de France pp 1- 42 http://www.banquefrance.fr/ .

472. Li J, Abrahamsson $\mathrm{J} T 2011$ New money, new problems: A qualitative study of the conflicts between venture capitalists and entrepreneurs in Sweden Ph.D. dissertation Umeå University Sweden http://umu.divaportal.org/smash/record.jsf?pid=diva2:426612 .

473. Samila S, Sorenson O 2011 Venture capital, entrepreneurship, and economic growth The Review of Economics and Statistics 93 (1) pp 338-349 doi:10.1162/REST_a_00066.

474. Tian X 2011 The causes and consequences of venture capital stage financing Journal of Financial Economics 101 pp 132 - 159.

475. Diaconu M 2012 Characteristics and drivers of venture capital investment activity in Romania Theoretical and Applied Economics vol XIX no 7 (572) pp 111 - 132.

476. Gvazdaityte A 2012 The analysis of the conditions needed for building venture capital industry in Lithuania Journal of Business Management and Economics vol 3 (3) ISSN 2141-7482 pp 96 - 105. 
477. Lazarevski D, Mrsik J, Smokvarski E 2012 Evolution of the venture capital financing for growing small and medium enterprises in Central and Eastern Europe countries: The case of Macedonia MPRA Paper No. 41997 Munich University Munich Germany pp 1 - 12 http://mpra.ub.uni-muenchen.de/41997/ .

478. Ledenyov V O, Ledenyov D O 2012a Shaping the international financial system in century of globalization Cornell University NY USA www.arxiv.org 1206.2022.pdf pp 1-20.

479. Ledenyov V O, Ledenyov D O 2012b Designing the new architecture of international financial system in era of great changes by globalization Cornell University NY USA www.arxiv.org 1206.2778.pdf pp 1 - 18.

480. Ledenyov D O, Ledenyov V O 2012c On the new central bank strategy toward monetary and financial instabilities management in finances: econophysical analysis of nonlinear dynamical financial systems Cornell University NY USA www.arxiv.org 1211.1897.pdf pp $1-8$.

481. Ledenyov D O, Ledenyov V O 2012d On the risk management with application of econophysics analysis in central banks and financial institutions Cornell University NY USA www.arxiv.org 1211.4108.pdf pp 1 - 10.

482. Ledenyov D O, Ledenyov V O 2012e Nonlinearities in microwave superconductivity Cornell University NY USA www.arxiv.org 1206.4426.pdf pp 1 - 919.

483. Ledenyov V O, Ledenyov D O, Ledenyov O P 2012f Features of oxygen and its vacancies diffusion in $\mathrm{YBa}_{2} \mathrm{Cu}_{3} \mathrm{O}_{7-\delta}$ thin films near to magnetic quantum lines Cornell University NY USA www.arxiv.org 1206.5635v1.pdf pp 1 - 7.

484. Ledenyov D O, Ledenyov V O 2013a On the optimal allocation of assets in investment portfolio with application of modern portfolio management and nonlinear dynamic chaos theories in investment, commercial and central banks Cornell University NY USA www.arxiv.org 1301.4881.pdf pp 1 - 34.

485. Ledenyov D O, Ledenyov V O 2013b On the theory of firm in nonlinear dynamic financial and economic systems Cornell University NY USA www.arxiv.org 1206.4426v2.pdf pp $1-27$.

486. Ledenyov D O, Ledenyov V O 2013c On the accurate characterization of business cycles in nonlinear dynamic financial and economic systems Cornell University NY USA www.arxiv.org 1304.4807.pdf pp 1 - 26.

487. Ledenyov D O, Ledenyov V O 2013d To the problem of turbulence in quantitative easing transmission channels and transactions network channels at quantitative easing policy 
implementation by central banks Cornell University NY USA www.arxiv.org 1305.5656.pdf pp $1-40$.

488. Ledenyov D O, Ledenyov V O 2013e To the problem of evaluation of market risk of global equity index portfolio in global capital markets MPRA Paper no 47708 Munich University Munich Germany pp 1 - 25 http://mpra.ub.uni-muenchen.de/47708/ .

489. Ledenyov D O, Ledenyov V O 2013f Some thoughts on accurate characterization of stock market indexes trends in conditions of nonlinear capital flows during electronic trading at stock exchanges in global capital markets MPRA Paper no 49964 Munich University Munich Germany pp 1 - 52 http://mpra.ub.uni-muenchen.de/49964/ .

490. Ledenyov D O, Ledenyov V O 2013g On the Stratonovich - Kalman - Bucy filtering algorithm application for accurate characterization of financial time series with use of statespace model by central banks MPRA Paper no 50235 Munich University Munich Germany pp 1 - 52 http://mpra.ub.uni-muenchen.de/50235/ .

491. Ledenyov D O, Ledenyov V O 2013h Tracking and replication of hedge fund optimal investment portfolio strategies in global capital markets in presence of nonlinearities MPRA Paper no 51176 Munich University Munich Germany pp 1 - 92 http://mpra.ub.unimuenchen.de/51176/ .

492. Lim K, Cu B 2012 The effects of social networks and contractual characteristics on the relationship between venture capitalists and entrepreneurs Asia Pacific Journal of Management 29 (3) pp 573 - 596 doi:10.1007/s10490-010-9212-x .

493. Rosenbusch N, Brinckmann J, Müller V 2012 Does acquiring venture capital pay off for the funded firms? A meta-analysis on the relationship between venture capital investment and funded firm financial performance Journal of Business Venturing http://dx.doi.org/10.1016/j.jbusvent.2012.04.002 .

494. Pommet S 2012 The survival of venture capital backed companies: An analysis of the French case GREDEG Working Paper no2012-14 University of Nice-Sophia Antipolis and GREDEG CNRS France pp 1 - 24 http://www.gredeg.cnrs.fr/working-papers.html .

495. Yitshaki R 2012 Relational norms and entrepreneurs' confidence in venture capitalists' cooperation: The mediating role of venture capitalists' strategic and managerial involvement Venture Capital 14 (1) pp 3 - 59 doi:10.1080/13691066.2012.662839 .

496. Alqatawni $\mathrm{T} 2013$ The relationship conflict between venture capital and entrepreneur MPRA Paper no 48006 Munich University Munich Germany pp 1 - 12 http://mpra.ub.unimuenchen.de/48006/ . 
497. Brettel M, Mauer R, Appelhoff D 2013 The entrepreneur's perception in the entrepreneur- $V C F$ relationship: the impact of conflict types on investor value Venture Capital pp 1 - 25. doi:10.1080/13691066.2013.782625 .

498. Pennacchio L 2013 The causal effect of venture capital backing on the underpricing of Italian IPOs MPRA Paper no 48695 Munich University Munich Germany pp 1 - 44 http://mpra.ub.uni-muenchen.de/48695/ .

499. Stuetzer M, Obschonka M, Schmitt-Rodermund E 2013 Balanced skills among nascent entrepreneurs MPRA Paper no 48641 Munich University Munich Germany pp 1 - 39 http://mpra.ub.uni-muenchen.de/48641/ http://www.springerlink.com/content/e73m7t6j82733411/ .

500. Bachelier L 1900 Theorie de la speculation Annales de l'Ecole Normale Superieure Paris France vol 17 pp 21-86.

501. Osborne M F M 1959 Brownian motion in the stock market Operations Research 7 pp $145-173$.

502. Alexander S S 1961 Price movements in speculative markets: Trends or random walks Industrial Management Review 2 pp 7 - 26.

503. Shiryaev A N 1961 The problem of the most rapid detection of a disturbance in a stationary process Soviet Mathematical Doklady 2 pp 795 - 799.

504. Shiryaev A N 1963 On optimal methods in quickest detection problems Theory of Probability and its Applications 8 (1) pp 22 - 46.

505. Shiryaev A N 1964 On Markov sufficient statistics in non-additive Bayes problems of sequential analysis Theory of Probability and its Applications 9 (4) pp 670 - 686.

506. Shiryaev A N 1965 Some exact formulas in a 'disorder' problem Theory of Probability and its Applications 10 pp 348 - 354.

507. Grigelionis B I, Shiryaev A N 1966 On Stefan's problem and optimal stopping rules for Markov processes Theory of Probability and its Applications 11 pp 541 - 558.

508. Shiryaev A N 1967 Two problems of sequential analysis Cybernetics 3 pp 63 - 69.

509. Shiryaev A N 1978 Optimal stopping rules Springer Berlin Germany.

510. Shiryaev A N 1998a Foundations of stochastic financial mathematics vol 1 Fazis Scientific and Publishing House Moscow Russian Federation ISBN 5-7036-0044-8 pp 1 - 492.

511. Shiryaev A N 1998b Foundations of stochastic financial mathematics vol 2 Fazis Scientific and Publishing House Moscow Russian Federation ISBN 5-7036-0044-8 pp 493-1017. 
512. Graversen S E, Peskir G, Shiryaev A N 2001 Stopping Brownian motion without anticipation as close as possible to its ultimate maximum Theory of Probability and its Applications 45 pp 125 - 136 MR1810977 http://www.ams.org/mathscinetgetitem?mr=1810977.

513. Kallsen J, Shiryaev A N 2001 Time change representation of stochastic integrals Theory of Probability and its Applications $\quad \mathbf{4 6}$ pp $579 \quad$ - 585 MR1978671 http://www.ams.org/mathscinet-getitem?mr=1978671 .

514. Kallsen J, Shiryaev A N 2002 The cumulant process and Esscher's change of measure Finance Stoch 6 pp 397 - 428 MR1932378 http://www.ams.org/mathscinetgetitem?mr=1932378 .

515. Shiryaev A N 2002 Quickest detection problems in the technical analysis of the financial data Proceedings Mathematical Finance Bachelier Congress Paris France (2000) Springer Germany pp 487 - 521 MR1960576 http://www.ams.org/mathscinet-getitem?mr=1960576 .

516. Jacod J, Shiryaev A N 2003 Limit theorems for stochastic processes 2nd edition Grundlehren der Mathematischen Wissenschaften [Fundamental Principles of Mathematical Sciences] 288 Springer Berlin Germany MR1943877 http://www.ams.org/mathscinetgetitem?mr=1943877

517. Peskir G, Shiryaev A N 2006 Optimal stopping and free-boundary problems Lectures in $\begin{array}{lllll}\text { Mathematics } & \text { ETH } & \text { Zürich } & \text { Birkhäuser } & \text { Switzerland }\end{array}$ http://www.ams.org/mathscinet-getitem?mr=2256030 .

518. Feinberg E A, Shiryaev A N 2006 Quickest detection of drift change for Brownian motion in generalized Bayesian and mini-max settings Statistics \& Decisions 24 (4) pp $445-470$.

519. du Toit J, Peskir G, Shiryaev A N 2007 Predicting the last zero of Brownian motion with drift Cornell University NY USA pp 1- 17 http://arxiv.org/abs/0712.3415v1 .

520. Shiryaev A N 2008a Generalized Bayesian nonlinear quickest detection problems: on Markov family of sucient statistics Mathematical Control Theory and Finance Proceedings of the Workshop of April 10-14 2007 Lisbon Portugal Sarychev A et al editors Springer Berlin Germany pp 377 - 386.

521. Shiryaev A N 2008b Optimal stopping rules $3^{\text {rd }}$ edition Springer Germany.

522. Eberlein E, Papapantoleon A, Shiryaev A N 2008 On the duality principle in option pricing: Semimartingale setting Finance Stoch 12 pp 265 - 292 http://www.ams.org/mathscinet-getitem?mr=2390191 . 
523. Shiryaev A N, Novikov A A 2009 On a stochastic version of the trading rule "Buy and Hold" Statistics \& Decisions 26 (4) pp 289 - 302.

524. Eberlein E, Papapantoleon A, Shiryaev A N 2009 Esscher transform and the duality principle for multidimensional semimartingales The Annals of Applied Probability vol 19 no 5 pp 1944 - 1971 http://dx.doi.org/10.1214/09-AAP600 http://arxiv.org/abs/0809.0301v5 .

525. Shiryaev A N, Zryumov P Y 2009 On the linear and nonlinear generalized Bayesian disorder problem (discrete time case) optimality and risk - modern trends in mathematical finance The Kabanov Festschrift Delbaen F et al editors Springer Berlin Germany pp 227 - 235.

526. Gapeev P V, Shiryaev A N 2010 Bayesian quickest detection problems for some diffusion processes Cornell University NY USA pp 1 - 25 http://arxiv.org/abs/1010.3430v2 .

527. Karatzas I, Shiryaev A N, Shkolnikov M 2011 The one-sided Tanaka equation with drift Cornell University NY USA http://arxiv.org/abs/1108.4069v1 .

528. Shiryaev A N, Zhitlukhin M V 2012 Optimal stopping problems for a Brownian motion with a disorder on a finite interval Cornell University NY USA pp 1 - 10 http://arxiv.org/abs/1212.3709v1 .

529. Zhitlukhin M V, Shiryaev A N 2012 Bayesian disorder detection problems on filtered probability spaces Theory of Probability and Its Applications 57 (3) pp 453 - 470.

530. Feinberg E A, Mandava M, Shiryaev A N 2013 On solutions of Kolmogorov's equations for nonhomogeneous jump Markov processes Cornell University NY USA pp 1 - 15 http://arxiv.org/abs/1301.6998v3 .

531. Akerlof G, Stiglitz J E 1966 Investment, income and wages Econometrica 34 (5) p 118.

532. Stiglitz J E 1969 Theory of innovation: Discussion American Economic Review 59 (2) pp $46-49$.

533. Rothschild M, Stiglitz J 1976 Equilibrium in competitive insurance markets: An essay on the economics of imperfect information Quarterly Journal of Economics 90 pp 629 - 649.

534. Stiglitz J, Weiss A 1981 Credit rationing in markets with incomplete information American Economic Review 71 pp 393 - 409.

535. Stiglitz J E 1988 Randomization with asymmetric information RAND Journal of Economics 19 (3) pp 344 - 362.

536. Greenwald B, Stiglitz J E 1990 Asymmetric information and the new theory of the firm: Financial constraints and risk behavior American Economic Review 80 (2) pp 160 - 165. 
537. J E Stiglitz 2001, 2002 Joseph E Stiglitz - Biographical The Sveriges Riksbank Prize in Economic Sciences in Memory of Alfred Nobel 2001 p 1 http://www.nobelprize.org/nobel_prizes/economic-sciences/laureates/2001/stiglitz-bio.html .

538. Richiardi M, Gallegati M, Greenwald B, Stiglitz J 2007 The asymmetric effect of diffusion processes: Risk sharing and contagion Global Economy Journal vol 8 issue 3 pp 1 - 10 ISSN (Online) 1524-5861 DOI: 10.2202/1524-5861.1365 .

539. Stiglitz J E 2013 Five years in limbo Columbia University 3022 Broadway NY USA http://www8.gsb.columbia.edu/chazen/globalinsights/node/218/Five\%20Years\%20in\%20Li mbo\# .

540. Bernanke B S 1979 Long-term commitments, dynamic optimization, and the business cycle Ph. D. Thesis Department of Economics Massachusetts Institute of Technology USA.

541. Bernanke B S, Blinder A S 1992 The federal funds rate and the channels of monetary transmission American Economic Review 82 (4) pp 901-921.

542. Bernanke B S, Gertler M 1995 Inside the black box: The credit channel of monetary policy transmission Journal of Economic Perspectives 9 (4) pp 27-48.

543. Bernanke B S 2002 Deflation: "Making sure it doesn't happen here." Speech before the National Economists Club Washington DC http://www.federalreserve.gov.

544. Bernanke B S 2004 The great moderation www.federalreserve.gov.

545. Bernanke B S, Reinhart V R 2004 Conducting monetary policy at very low short-term interest rates The American Economic Review vol 94 no 2 pp 85-90.

546. Bernanke B S, Reinhart V R, Sack B P 2004 Monetary policy alternatives at the zero bound: an empirical assessment Brookings Papers on Economic Activity Issue 2 pp 1-78.

547. Bernanke B S 2007 The financial accelerator and the credit channel Speech at The Credit Channel of Monetary Policy in the Twenty-first Century Conference Federal Reserve Bank of Atlanta Georgia USA.

548. Bernanke B S 2009a The crisis and the policy response Federal Reserve USA.

549. Bernanke B S 2009b On the outlook for the economy and policy Bank for International Settlements Basel Switzerland http://www.bis.org/review/r091119a.pdf .

550. Bernanke B S 2009c The Federal Reserve's balance sheet - an update Bank for International Settlements Basel Switzerland http://www.bis.org/review/r091013a.pdf .

551. Bernanke B S 2009d Regulatory reform Bank for International Settlements Basel Switzerland http://www.bis.org/review/r091006a.pdf .

552. Bernanke B S 2009e Policy responses to the financial crisis Public Lecture on 13.01.2009 London School of Economics and Political Science London UK. 
http://richmedia.lse.ac.uk/publicLecturesAndEvents/20090113_1300_policyResponsesToThe FinancialCrisis.mp3 .

553. Bernanke B S 2010a Monetary policy and the housing bubble Annual Meeting of the American Economic Association Atlanta Georgia USA.

554. Bernanke B S 2010b Causes of the recent financial and economic crisis testimony before the Financial Crisis Inquiry Commission Washington USA www.federalreserve.gov/newsevents/testimony/bernanke20100902a.htm .

555. Bernanke B S 2012a Some reflections on the crisis and the policy response Rethinking Finance: Perspectives on the Crisis conference sponsored by the Russell Sage Foundation and The Century Foundation New York www.federalreserve.gov/newsevents/speech/bernanke20120413a.htm .

556. Bernanke B S 2012b Monetary policy since the onset of the crisis The Changing Policy Landscape symposium sponsored by the Federal Reserve Bank of Kansas City Jackson Hole Wyoming USA www.federalreserve.gov/newsevents/speech/bernanke20120831a.htm .

557. Bernanke B S 2013a Financial and economic education 13th Annual Redefining Investment Strategy Education (RISE) Forum Dayton Ohio USA.

558. Bernanke B S 2013b Stress testing banks: What have we learned? Maintaining Financial Stability: Holding a Tiger by the Tail conference sponsored by the Federal Reserve Bank of $\begin{array}{llll}\text { Atlanta Stone } & \text { Mountain } & \text { USA }\end{array}$ www.federalreserve.gov/newsevents/speech/bernanke20130408a.htm .

559. Bernanke B S 2013c Monitoring the financial system 49th Annual Conference on Bank Structure and Competition sponsored by the Federal Reserve Bank of Chicago Chicago Illinois USA pp 1 - 16.

560. Bernanke B S 2013d A century of U.S. central banking: Goals, frameworks, accountability The first 100 years of the Federal Reserve: The policy record, lessons learned, and prospects for the future conference sponsored by the National Bureau of Economic Research Cambridge Massachusetts USA.

561. Bernanke B S, Blanchard O, Summers L H, Weber A A 2013a What should economists and policymakers learn from the financial crisis? Public Lecture on 25.03.2013 London School of Economics and Political Science London UK http://media.rawvoice.com/lse_publiclecturesandevents/richmedia.lse.ac.uk/publiclecturesan devents/20130325_1715_whatShouldEconomistsAndPolicymakersLearn.mp4 ; http://www.federalreserve.gov/newsevents/speech/bernanke20130325a.htm. 
562. Bernanke 2013b Teaching and learning about the Federal Reserve A Teacher Town Hall Meeting: 100 Years of the Federal Reserve Washington DC USA pp 1 - 5.

563. Bernanke 2013c The crisis as a classic financial panic Fourteenth Jacques Polak Annual Research Conference Washington DC USA pp 1 - 9.

564. Shiller R J, Pound J 1989 Survey evidence on the diffusion of interest and information among investors Journal of Economic Behavior and Organization 12 pp 47-66.

565. Fischer S 1999 On the need for an international lender of last resort Journal of Economic Perspectives vol 13 Fall pp 85 - 104.

566. Stock J H, Watson M W 2002 Macroeconomic forecasting using diffusion indexes Journal of Business and Economic Statistics 20 no 2 pp 147 - 162.

567. Xiaohong Chen, Hansen L P, Carrasco M 2009 Nonlinearities and temporal dependence CIRANO ISSN 1198-8177 pp 1 - 33.

568. Kirzner I 1973 Competition and entrepreneurship University of Chicago Press Chicago USA.

569. Jaffee $D$, Russell $T 1976$ Imperfect information, uncertainty and credit rationing Quarterly Journal of Economics 90 pp 651 - 666.

570. Jensen M C, Meckling W H 1976 Theory of the firm: Managerial behavior, agency costs and ownership structure Journal of Financial Economics 3 pp 305 - 360.

571. Leland H E, Pyle D H 1977 Information asymmetries, financial structure, and financial intermediation The Journal of Finance 32 pp 371 - 387.

572. Lucas R E 1978 On the size distribution of business firm Bell Journal of Economics 9 (2) pp $508-523$.

573. Greene W H 2008 Econometric Analysis $6^{\text {th }}$ edition Prentice Hall USA.

574. Martin R L (1998-1999, 2005-2006) Private communications on the venture capital investment strategies Rotman School of Management University of Toronto Canada.

575. Hull J C (2005-2006) Private communications on the venture capital investment strategies Rotman School of Management University of Toronto Canada.

576. Müller K A 1997 Private communications on the oxygen diffusion in superconducting oxides Alexandra Hotel Loen Norway.

577. Chu C W 1997 Private communications on the oxygen diffusion in superconducting oxides Alexandra Hotel Loen Norway.

578. Goretta K 1998 Private communications on the oxygen diffusion in superconducting oxides Bologna Italy. 